\title{
THE UNIFORM COMMERCIAL CODE AND CONTRACT LAW: SOME SELECTED PROBLEMS
}

\section{TABLE OF CONTENTS}

Page

INTRODUCTION 837

Part I. Formation of a Contract-Acceptance $\ldots \ldots \ldots \ldots \ldots \ldots \ldots \ldots .839$

Acceptance by the Seller ............................ 839

Acceptance Which Varies From the Offer ............... 850

Conclusion $\ldots \ldots \ldots \ldots \ldots \ldots \ldots \ldots \ldots \ldots \ldots \ldots \ldots \ldots \ldots \ldots, 86 \ldots \ldots$

Part II. Tender of Nonconforming Goods-Buyer's Duties Upon RightFUL Rejection ................................ 864

Buyer's Preliminary Duties Upon Rejection ............. 865

Duties of a Merchant Buyer ....................... 866

Merchant Buyer's Duties as to Perishable Goods .............. 869

Exceptions and Special Cases $\ldots \ldots \ldots \ldots \ldots \ldots \ldots \ldots \ldots \ldots, 872$

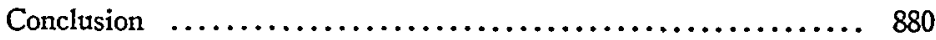

Part III. Performance-The Doctrine of Impossibility $\ldots \ldots \ldots \ldots \ldots \ldots \ldots .880$

Adjusting a Disrupted Deal: Excusing the Seller Because of Supervening Facts $\ldots \ldots \ldots \ldots \ldots \ldots \ldots \ldots \ldots \ldots \ldots \ldots, 881$

Excuse: Failure of Presupposed Conditions ................ 885

Selected Problems Involving Impracticability .............. 890

Procedure Upon Claim of Excuse .................... 900

Buyer's Excuse When Contract Has Lost Its Ultimate Value:

Frustration ............................... 904

Conclusion $\ldots \ldots \ldots \ldots \ldots \ldots \ldots \ldots \ldots \ldots \ldots \ldots \ldots \ldots \ldots . \ldots \ldots$

Part IV. Traffic in Contract Rights and Duties-Assignagent and

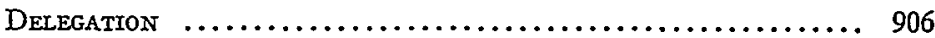

Assignment of Rights ... ........................ 907

Substituted Performance-Delegation of Duties ............ 913

Modification of Assigned Contracts .................... 918

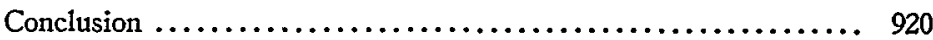

Beyond the Code: Application and Analogy $\ldots \ldots \ldots \ldots \ldots \ldots \ldots \ldots \ldots \ldots . . \ldots 21$ 


\section{INTRODUCTION *}

The Uniform Commercial Code, ${ }^{1}$ a product of long and arduous effort by a large task force of legal scholars and practicing attorneys, ${ }^{2}$ attempts an exhaustive re-evaluation of commercial dealings. All phases of the commercial law are treated so as to give effect, more completely than did previous statutes and common law, to the reasonable expectations of those whose relations are established in the market place rather than in the courtroom. The result is the establishment of a statutory basis for the entire spectrum of commercial transactions-from sales of goods to security financing arrangements.

In the course of this broad endeavor, and at least partially to avoid the interference of rigorous common-law doctrines tangential to the commercial dealings which the code seeks to control, ${ }^{3}$ several sections are devoted to a reformulation of some of the principles of contract law. From problems of contract formation through those of remedies, the draftsmen selected the important features of the contract law governing the sale of goods and codified the doctrine deemed most desirable in each instance. At times the code provision is merely a restatement of prior law; in many instances the common law rules are modified or completely abandoned. 4 For example, one section permits firm offers without consideration $;^{5}$ an-

* The Law Review wishes to express its appreciation to the following companies which were kind enough to furnish copies of their business forms: Aluminum Company of America, Futorian-Stratford Furniture Company, Midvale-Heppenstall Company, Serv-Agen Corporation.

1. PA. Stat. Ann. tit. 12A (Purdon 1954) (hereinafter cited as UCC). The comments to the code sections are those in the 1952 Official Draft.

2. The code was evolved and nurtured by the American Law Institute and the Commissioners on Uniform State Laws. Chief and Associate Chief Reporters were Karl Llewellyn and Soia Mentschikoff. The sales article was given final approval at a joint meeting in May 1951. Pennsylvania is the first and only state to adopt the code, approving it April 6,1953, effective July 1, 1954. Since then the New York Law Revision Commission, after detailed study of the effect of the provisions of the code upon the law of the state, recommended its disapproval of the code as it was then written. See Law Revision Commission of the State of New York, Report to the Legislature Relating to the Uniform Commercial Code, LEG. Doc. No. 65(A) (1956).

3. UCC arts. 2 (Sales), 3 (Commercial Paper), 4 (Bank Deposits and Collections), 5 (Documentary Letters of Credit), 6 (Bulk Transfers), 7 (Warehouse Receipts, Bills of Lading and Other Documents of Title), 8 (Investment Securities), 9 (Secured Transactions; Sales of Accounts, Contract Rights and Chattel Paper).

4. E.g., UCC § 2-203.

5. UCC \& 2-205. 
other modifies the traditional distinctions between acceptance and counteroffer. $^{6}$ The common law refusal to allow the offeree free choice as to the medium of acceptance is dealt with summarily, ${ }^{7}$ and in a few words the often hazy differences between bilateral and unilateral agreements are further blurred. ${ }^{8}$ A new standard for enforcing indefinite agreements is adopted. $^{9}$ The Statute of Frauds ${ }^{10}$ and the parol evidence rule ${ }^{11}$ are reformulated and modernized. Several common law rules of assignment and delegation are codified, clarified and altered. ${ }^{\mathbf{1 2}}$ The code makes no pretense to complete codification, ${ }^{13}$ nor does it attempt to restrict or affect case law in areas other than sale of goods..$^{14}$ Whether the code effectuates or, perhaps, exceeds the draftsmen's' intentions can be determined only after a detailed investigation of some of the changes wrought by the code and their value to the businessman.

The code has been part of the statutory law of Pennsylvania for almost two years; during that time litigation involving the code has arisen in only one case ${ }^{15}$ and that not involving the contract provisions. Although analysis might therefore be uncertain and evaluation difficult, these problems are offset to a large extent by the detail contained in the draftsmen's comments to each section. This Note will examine four problem areas in the law of contracts: formation of a contract, buyer's remedies upon rejection, impossibility of performance, and assignment and delegation. In each the inquiry will be whether and to what extent the code is an effective regulator of relationships between the parties to a commercial transaction. Relevant provisions will be examined in light of the interests to be protected in each instance, including the efficient functioning of business organizations, and the efficacy and suitability of the rules established to safeguard those interests.

6. UCC $\$ 2-207(1)$.

7. UCC $\S 2-206(1)(a)$.

8. UCC $\S \S 2-206(1)(b), 2-206(2)$, (3). See also UNIForm CoMmerCial Code $\S \S 2-206$ (1) (b), (2) (official ed. 1957) (hereinafter cited as 1957 DRAFT) and text and citations at note 32 infra.

9. UCC \& 2-204(3).

10. UCC \& $2-201$.

11. UCC \& 2-202.

12. E.g., UCC $\S 2-210,9-318$.

13. See, e.g., UCC $\$ \S 2-206$, comment $3 ; 2-210$, comment 7.

14. See e.g., 1957 DRAFT $\$ 2-102$; UCC $\$$ 2-204(1), 2-205, 2-206(1) (b). But cf. UCC $\$ \$ 2-206$ (1) (a), (3), 2-207. However, the definition is broad: "Goods' means all things (including specially manufactured goods) which are movable at the time of identification to the contract for sale other than the money in which the price is to be paid, investment securities (Article 8) and things in action. 'Goods' also include the unborn young of animals and growing crops and other identified things attached to realty and capable of severance without material harm thereto as described in the section on goods to be severed from realty. . . " UCC \& 2-105(1).

15. Denkin v. Sterner, 70 York Leg. Rec. 105 (York County, Pa. C.P. July 16, 1956), 105 U. PA. L. Rev. 764 (1957). 


\section{PART I. FORMATION OF A CONTRACT-ACCEPTANCE}

A buisinessman, upon receiving an offer to enter into a business transaction which he finds agreeable, must determine what he may and should do in response. If he is the seller, he might ship the goods requested or he might choose to acknowledge the buyer's order $;^{16}$ as either seller or buyer, he might incorporate in his acceptance a condition not anticipated in the offer. ${ }^{17}$ Each of these possibilities merits separate treatment as a statutory and commercial problem. The businessman may have to know whether an acceptance which misstates a term of the offer or includes additional conditions results in a binding contract; ${ }^{18}$ if so, whether the operative terms are those included in the offer or in the acceptance. Furthermore, where the seller-offeree ships nonconforming goods, the consequences will depend upon whether the shipment was an accommodation to the buyer or was intended as an acceptance of the offer. ${ }^{19}$ Part I will examine the impact of the code upon each of these situations.

\section{Acceptance by the Seller}

Preventing the Offeror's Pozver of Revocation: Promise or Performance

One of the recurring problems in the law of contract formation is that of ascertaining the point at which the offeror may no longer affect the offeree's power to consummate a contract. This may be illustrated by the following hypothetical. $B$, by letter dispatched on Friday, requests $S$ to send 1000 widgets on the following Thursday. At this point, $B$ became an "offeror"; he raised in S reasonable expectations that a sale of widgets to $\mathrm{B}$ might be concluded. ${ }^{20}$ Theoretical and practical legal problems arise when $B$, on Monday, before hearing from $S$, changes his mind ${ }^{21}$ and sends $\mathrm{S}$ a letter telling him to disregard the offer. It is possible that before Monday S sent a letter to B acknowledging the "order" and stating that he will ship on or before Thursday. Or by Monday the widgets might

16. UCC $\$ 2-206(1)(b),(2),(3)$. See text at notes $22-33$ infra.

17. See UCC \$2-207. See text at notes 59-75 infra.

18. See UCC $\$ 2-204(1), 2-206(1)(a), 2-207(1)$. See text at notes 59-89 infra.

19. See UCC $\$ 2-206(2)$. See text at notes $54-58$ infra.

20. See 1 Corbin, Contracts $\$ \S 22-28$ (1950); 1 Williston, Contracts $\$ \S 24-27$ (rev. ed. 1936); $c f$. RESTATEMENT, ConTraCTS $\$ 25$ (1932). None of the varied problems associated with determining whether a businessman has made an offer will be considered in this Note.

21. B's desire not to be bound by a business agreement might arise from a great variety of situations : he might decide that it has taken the seller too long to reply and he would rather get the goods elsewhere; B's business might have undergone some rapid and unpredictable change before the goods are paid for or possibly before they are shipped; or $B$ might change his mind because $S$ has taken on the job but started to do it in the wrong way. These are problems which involve businessmen's relations after a "contract" has been consummated. The analysis here will concern itself only with determining the point at which courts should not allow $B$ to change his mind without incurring legal liability. 
have been shipped by $S$ and in transit to $B$. Finally, $S$ might have commenced production of widgets for B before B's second letter was received.

The common law approach to determine whether $B$ may renege with impunity is circuitous. Initially, a court would determine whether the offer was for a "unilateral" 22 or "bilateral" contract: ${ }^{23}$ did B request that $S$ ship widgets or did he request S's promise to ship widgets? This inquiry is made necessary by the emphasis which the common law places upon the vagaries of $B$, the offeror-he is said to be the "master of his offer." 24 He prescribes the terms on which he will deal. To complete a legally enforceable bargain, the offeree must comply with exactitude; until the offer is so complied with and hence "accepted," B may revoke it at will..$^{25}$ If the offer was for a unilateral contract, B could cancel his order and avoid being bound until S "accepted" by furnishing the requested performance-widget shipment. ${ }^{26}$ Similarly, if B had requested S's promise to ship the goods, $B$ could revoke his offer until $S$ indicates such a promise; for $S$ to begin producing widgets for B's order would not suffice. ${ }^{27}$

22. "A unilateral contract is one in which no promisor receives a promise as consideration for his promise." RESTATEMENT, CoNTRACTS $\$ 12$ (1932).

23. "A bilateral contract is one in which there are mutual promises between two parties to the contract; each party being both a promisor and a promisee." Ibid.

24. "And it is because a bargainor is in the classical ideology the utter master of his bargain that an offeror is conceived as the utter master of his offer. He being thus the master, he can dictate that even language of express assent by the offeree shall not amount to assent in law... This is because such matters do not satisfy the consideration requirement which is laid down by the offeror's supposed insistence upon 'the act' as the only thing for which he is "bargaining his promise." Ilewellyn, Our Case-Law of Contract: Offer and Acceptance, II, 48 YALE L. J. 779, 786 (1939).

25. See REstatearent, ConTracts $\$ 59$ (1932): "Except as this rule is qualified by $\S \S 45,63,72$, an acceptance must comply exactly with the requirements of the offer, omitting nothing from the promise or performance requested."

26. "A offers B $\$ 5$ for a book. B promptly communicates to $A$ a promise to give the book. There is no contract, since $A$ requested the actual delivery of the book, not a mere promise to give it." RESTATEMENT, CoNTRACr's $\$ 59$, illustration 2 (1932). See also 1 WiLlistoN, op. cit. supra note 20 , at 165 : "It seems difficult on theory to question the power of one who offers to enter a unilateral contract to withdraw his offer at any time until performance has been completed by the offeree, but great injustice may arise if the offeror's power of revocation continues so long." But see Stoljar, The False Distinction Between Bilateral and Unilateral Contracts, 64 YALE L. J. 515 (1955).

27. Cf. WiLliston, op. cit. sicpra note $20, \S 65$. Generally, the rule is inferred from statements about acts of the offeree which constitute acceptance. "If an offer requests a promise from the offeree, and the offeree without making the promise actually does or tenders what he was requested to promise to do, there is a contract. . .provided such performance is completed or tendered within the time allowable for accepting by making a promise." Restatement, Contracts \& 63 (1932). See Pioneer Box Co. v. Price Veneer \& Iumber Co., 132 Miss. 189, 96 So. 103 (1923) (seller did not accept offer by loading lumber ordered on to railroad car when no other acknowledgment by him over period of a month following order) ; Hampton Cotton Mills v. Hershfeld, 121 Misc. 518, 201 N.Y.S. 556 (Sup. Ct. 1923) (where seller-offeree furnished goods direct to buyer's customers on order without any other acceptance, executory portion of order at time of revocation is not binding upon buyer). But see Hercules Mfg. Co. v. Wallace, 124 Miss. 27, 86 So. 706 (1920) (order for generator accepted when seller places it on railroad car for shipment) ; Williams v. Emerson-Brantingham Implement Co., 198 S.W. 425 (Mo. Ct. App. 1917) (dictum); Whitman Agricultural Co. v. Strand, 8 Wash. 647, 36 Pac. 682 (1894) (sale consummated by seller-offeree's delivery of the goods to the carrier). 
The rigors of this classical approach ${ }^{28}$ are tempered in some jurisdictions by doctrines approved by the Restatement of Contracts. ${ }^{29}$ If B's offer is for a unilateral contract, Restatement section 45 states that he is not permitted to revoke once $S$ has begun to produce the widgets or prepare them for shipment to B. If, on the other hand, B requests a promise to deliver widgets, delivery by $S$ without ever having verbally accepted B's offer terminates B's power to cancel. ${ }^{30}$ No doctrine was devised, however, to prevent hardship which might result from a misinterpretation of the business shorthand in which B's offer is expressed; ${ }^{31}$ the most significant safeguard was perhaps the sensibilities of an intelligent judiciary.

The code represents an attempt at reorientation of legal doctrine to business fact. The specific provisions concerned with offer and acceptance have been said to dispense with the unilateral and bilateral contract dichotomy. ${ }^{32}$ Section 2-206, dealing with several contract problems which the common law did not satisfactorily solve, requires careful analysis. It provides:

"(1) Unless the contrary is unambiguously indicated by the language or circumstances

(a) an offer to make a contract shall be construed as inviting acceptance in any manner and by any medium reasonable in the circumstances;

28. "Those untruths and unwisdoms are, in the living usage of the word, "classical', which we have been rather generally taught to conceive as true and wise. It is of course the task of the case-law judges and case-law scholars to get rid of them, and to substitute others which better fit what Corbin deals with as the system of our caselaw-which means the going whole of case law in contradistinction to any intellectual 'system' that is not of our case-law, but only of our class-rooms." Llewellyn, supra note 24 , at $780-81$.

29. RESTATEMENT, Contracts $\& 45$ (1932): "If an offer for a unilateral contract is made, and part of the consideration requested in the offer is given or tendered by the offeree in response thereto, the offeror is bound by a contract, the duty of immediate performance of which is conditional on the full consideration being given or tendered within the time stated in the offer, or if no time is stated therein, within a reasonable time." Williston, after stating that the classical rule is most reasonable theoretically, comments that "as a matter of positive decision the right of the offeror to revoke his offer even after part performance by the offeree has the support of a few American cases, but in most of the few cases where the question has arisen the offeror has been held bound. It is not always clear on what theory." 1 WILLISTON, op. cit. supra note 20 , at 167-68. Corbin is more positive: "The second doctrine is to the effect that, in the case of an offer of a promise for an act or a series of acts, there is no contract until the acts constituting the acceptance are entirely completed. If the decisions now to be discussed are to be supported-and they must be-this second doctrine must be wholly abandoned." 1 CORBIN, op. cit. supra note 20, at 146. However, "beginning preparations though they may be essential to carrying out the contract or to accepting the offer, is not enough." RESTATEMENT, CoNTRACTS $\& 45$, comment a (1932). To the same effect see 1 WiLliston, op. cit. supra note 20, at 171.

30. See note 27 supra.

31. But see RESTATEMENT, Con'rRacts $\$ 31$ (1932): "In case of doubt it is presumed that an offer invites the formation of a bilateral contract by an acceptance amounting in effect to a promise by the offeree to perform what the offer requests, rather than the formation of one or more unilateral contracts by actual performance on the part of the offeree."

32. See Stoljar, supra note 26, at 516 \& n.5; Dechert \& Brennan, The Pennsylvania Uniform Commercial Code, PA. STAT. ANN. tit. 12A, XXXIII, XL (Purdon 1954). 
(b) an order or other offer to buy goods for prompt or current shipment can be accepted either by such shipment or by a prompt promise thereof.

"(2) Unless the seller states the contrary a shipment sent in response to an order to which it does not conform is an acceptance and at the same time a breach. But a shipment of nonconforming goods offered as an accommodation to the buyer in substitution for the goods described in the order is not an acceptance.

"(3) The beginning of a requested performance can be a reasonable mode of acceptance but in such a case an offeror who is not notified of acceptance within a reasonable time may treat the offer as having lapsed before acceptance."

Under this section a seller receiving an order for "goods for prompt or current shipment" has alternative methods of indicating his acceptance of the order. He may acknowledge buyer's order by a "prompt promise" or he may in fact ship the goods. Either alternative may be precluded by buyer if he is willing to permit seller to complete a binding agreement in only one of these ways or in some other specified fashion; but buyer's intention to contradict must be "unambiguously" indicated.

To this extent the meaning of section 2-206 is clear; uncertainty, however, bedevils further construction. For instance, may seller accept an order "for prompt or current shipment" other than by the methods designated in subsection (1) (b) ? To state the problem somewhat differently: does subsection (1) (b) prescribe the minimum action required of seller to form a contract, or is the subsection designed only to indicate that either "shipment" or a "prompt promise" is sufficient to foreclose buyer's revocation? It might be argued that the reference in subsection (1) (a) to "acceptance in any manner" permits seller to terminate buyer's power of revocation by any act indicating acceptance. However, the comments and other subsections allude to an offeree's behavior indicating his acceptance as his "mode of acceptance," 33 from which it may be inferred that the "manner" of acceptance in subsection (1) (a) refers only to the acceptable media of communication. Subsection (3), which includes no suggestion that its operation may be qualified by the offeror's specifications, states that the beginning of a requested performance "can be a reasonable mode of acceptance." Since the phrase "can be" acknowledges merely a possibility, and no instance is given of situations to which it applies, presumably recourse must be had to the common law to determine when beginning performance "can be" an acceptance.

This view is supported by the most recent amendment to the sectionsupposedly only a clarification-which changes the formulation to read "Where the beginning of a requested performance is a reasonable mode of

33. See UCC $\S 2-206(3)$, comment 2. 
acceptance. . . ." 34 Implicit in this construction is the assumption that subsection (3) is included to prevent the other provisions from negating the common law rule on acceptance by performance begun. The draftsmen's comment to section 2-206, which recognizes the continued operation of the common law rule, lends support to this assumption. ${ }^{35}$ If such be the case, and if "goods for prompt or current shipment" be construed as encompassing offers which at common law could be accepted by beginning performance, then it is necessary to construe subsection (1) (b) as exemplary rather than exclusive in order to avoid a conflict between that provision and subsection (3).

A broader interpretation of subsection (3) would find in the provision authority for a court to bind the offeror to a contract after the offeree's start of performance not only where the common law so provides, but also where normal business practice recognizes in these circumstances that the offeror is bound or where the offeror was sufficiently aware of the offeree's expenditure of money and effort that it would offend a sense of fairness to permit the offeror thereafter to deny a contract. Nevertheless, the narrower interpretation seems more appropriate. The draftsmen's comment explicitly makes clear that the major object of subsection (3) was to establish a requirement of notice to the offeror soon after the offeree's acceptance by beginning performance. ${ }^{36}$ Absent express indication of any other variation from the common law, subsection (3) must be taken as preserving the common-law framework, not as making significant additions to it. Regardless of the preferred interpretation, the statutory structure is sufficiently complex that assessment of its value should be postponed until attention has been focused on the factual situations in which an expression of acceptance becomes important.

Whether the changes in contract law introduced by the code are of value, and whether these alterations are merely a first step toward a more complete codification should depend upon the needs of businessmen in bargaining situations. Initially, therefore, bargaining situations must be analyzed to determine the best statutory framework to satisfy these needs. Several interests must be protected: the offeree must have reasonable freedom in his choice of behavior that will be deemed responsive to an offer. ${ }^{37}$

This freedom, however, must be subject to safeguards which properly assure the offeror that conforming goods will be furnished to him. ${ }^{38}$ Both

34. UCC § 2-206(2), 1957 DRAFT.

35. "Nothing in this section, however, bars the possibility that under the common law, performance begun may have an intermediate effect of temporarily barring revocation of the offer, or at the offeror's option, final effect in constituting acceptance." UCC $\S 2-206$, comment 3 .

36. Ibid.

37. One reason for this freedom is the possibility that the seller-offeree might reasonably rely upon the offeror's message and respond to it in a way he thinks adequate to make a binding "deal." Another reason is provided by business exigencies which might determine the steps which the seller-offeree will first take in reliance upon the offer. See note 57 infra.

38. "This assurance [notice to the offeror] is offered, to be relied on; and after the deal is 'on,' it is not to be withdrawn. Its value exists, however, almost wholly 
of these considerations must be so balanced as to permit rapid transactions in a commercial society. The needs of both parties will vary according to the factual context in which B's initial overture occurs. However, the factors may balance in particular situations, because businessmen frequently make deals in market place jargon which is not attuned to legal consequences, no valid distinctions can be made on the basis of the words used by the offeror alone. ${ }^{39}$ The offeror is always interested in performance no matter what phrases he uses; the offeree is interested only in gaining a profit by having an undisturbed opportunity to furnish the performance which the offeror has requested. Therefore, the needs of each will be analyzed without reference to the "form" of the offer. Proper evaluation of the code provisions may then be made and any modifications recommended in light of this analysis.

$\mathrm{B}$ and $\mathrm{S}$ might meet at a wholesale market. In response to B's statement "Give me 1000 widgets" $S$ might merely hand them over. At that moment their contract is formed. The validity of binding the parties at that point in such a face-to-face transaction is obvious. Variations from these facts, however, produce difficulties.

If Mrs. B enters a department store and tells the clerk "I will take that widget," it would be ridiculous to suggest that should she change her mind as the clerk is getting it or as he is bringing it to her he could insist that she take it, either because he had promised to get it for her or because he had actually started to do so. ${ }^{40}$ Although she had knowledge that the clerk undertook to furnish her with the widget and should have had no doubt that he would accomplish the undertaking within a reasonable time, no substantial harm can proceed from permitting Mrs. B to refuse to accept the goods. The possibility of Mrs. B's change of heart need not be recognized in formulating doctrine for contract formation. Nevertheless, granting this privilege to a non-merchant buyer seems justified.

because the assurance foreshadows the second thing which is also and simultaneously offered. That second thing is an ultimate actual performance of roughly indicated character which is to occur in due course." Llewellyn, supra note 24 , at 790 .

39. If $B$ sends a telegram to $S$ which states only "Ship 1000 widgets by truck C.O.D. next Thursday to arrive Saturday morning" little can be gained by "construing" the words to determine whether $B$ wanted shipment and only shipment or notice that $S$ would ship followed on Thursday by shipment. If B were asked he would probably answer that he wanted "widgets."

40. The cogent precept that "the customer is always right" prevents the occurrence of such a situation. In other sections of this Note it is suggested that reasonable business practice should be the ideal for legal doctrines. Wider freedom based upon this precept has not been granted to offerors, although the possibility has more than once been suggested. See, e.g., Llewellyn, supra note 24 , at 803 : "The case remains to be made, in ethics or in policy, for the snapping of the legal trap when the attempted retraction rolls in so swiftly that any action taken in reliance becomes questionable, or when the quantity or degree of action taken is patently slight, or even when the retracting side can demonstrate the absence of any such action. Plainly, in such situations, policy becomes more tenuous; and to my mind only resort to formalism can keep ethics from acknowledging 'moral' obligation to be here often on slippery footing. Neither do I believe it possible to find a consistent ethical basis for all the rules evolved by our courts in the matter." Nonetheless, Llewellyn finds adequate support for the normal rule. 
Other considerations, however, are present when B, a merchant, knowing that widgets are ready-made and normally shipped out as orders are received, sends a wire to $S$ asking him to ship 1000 widgets immediately. Had B ordered by telephone he would have been notified immediately of S's intention to undertake delivery of the widgets and a contract would have been formed even though B's ultimate assurance of delivery would not have been achieved until the goods were shipped. Lacking personal contact, S may provide $B$ with notice and assurance by actually shipping the goods. If the news of the shipment will reach $B$ almost as soon as a letter of intention to ship, there is every reason to permit $S$ to close the deal by shipment; he is giving B notice and as much assurance as is possible short of actual receipt of the goods. ${ }^{41}$ It would be harsh to permit $B$ to cancel the deal when $S$ has relied upon the offer to this extent. At common law, shipment would terminate the offeror's power of revocation only if the offer were for a unilateral contract and Restatement section 45 were followed in the jurisdiction. ${ }^{42}$ If the offer were for a bilateral contract, the offeree could ship subject to the risk that the buyer would revoke at any time before the shipment actually reached him. ${ }^{43}$ The code ignores these distinctions and permits orders for goods for prompt or current shipment to be accepted by shipment.

If, instead of shipping, $S$ sends a letter to $B$ saying that he plans to ship the widgets, $B$ has been given information but has only S's promise as assurance that he will receive the goods. $B$ will certainly be no less assured of performance than he had been without notice; ${ }^{44}$ he can be confident to the extent that his faith in S's integrity and ability to deliver the goods prompted his offer to buy from $S$. In addition, since the goods are ready-made, $B$ has more basis for assuming that $S$ would not undertake a promise without expecting to deliver; even if the goods are not readymade, if they are standard production-run items S's ability to estimate the demands upon his productive facilities for such items gives $B$ a measure of protection. Although the fact that $B$ has merely a limited amount of assurance affords a reasonable basis for permitting him to cancel his order at any time until $S$ ships, it nevertheless seems better to permit $S$ to close the deal by notice. This is the only means by which S's interest in the sale can be protected while giving him freedom to attend to other transactions. For business affairs to function in an orderly fashion the offeror must content himself with his offeree's promise unless the offeror is specifically aware that the promise is inadequate. Also, B's interest may be ade-

41. It may be assumed that even if $S$ ships without any notice of shipment, notice by the carrier will serve the dual function. At any rate, where notification alone is used the acceptance is normally effective when dispatched rather than when received. See RESTATEMENT, CoNTraCts \$ 64 (1932).

42. See note 29 supra.

43. See note 27 supra.

44. Of course, to the extent that the delay permits the possibility of a change in the circumstances out of which the offer arose, especially if the offeror contemplated immediate shipment, the offeror is less assured. Also, the very fact that $S$ cannot ship immediately might raise reasonable doubts in B's mind. 
quately protected by giving him a remedy in damages should $\mathrm{S}$ not fulfill his promise to ship. ${ }^{45}$

Where the order is for "prompt or current shipment," then, the seller should be permitted to respond and close the deal either by shipment or by notification. Should this conclusion, however, be extended to deny $B$ the power to restrict, even by "unambiguous" language, S's acceptance to one or the other of these means? ${ }^{46}$ Since B is interested only in ultimately obtaining widgets, there is no reason to allow him to reserve power to insist on acceptance by a promise alone and thereby avoid a deal after $S$ has relied on B's order to the point of placing the goods in transit. Since shipment fulfills commercial requirements for assurance to the buyer, it seems a sufficient standard by which to protect the-seller from the buyer's whims. Therefore, $B$ should not be able to preserve the right to revoke until he actually receives the goods. Because of the relative lack of assurance in a mere promise to ship, however, the offeror should be permitted to require that shipment alone deprive him of the ability to revoke. ${ }^{47}$ The "unambiguous contradiction" language of section 2-206 should be altered to permit limitation only of the seller's ability to close the deal by a promise to ship.

Although the code uses 'the term "goods for prompt or current shipment," no definition is afforded. In its broadest sense the phrase could encompass goods which are made to order, albeit in a short time, e.g., a birthday cake, and goods which are ready-made regardless of whether delivery is requested for the next day or the next month. Policy considerations may warrant different rules where goods are made to order than where they are ready-made. However, since the code permits "goods for prompt or current shipment" to be accepted by shipment or a prompt promise thereof, the offeree can select the mode consistent with his needs according to whether the goods are ready-made or for order, for immediate delivery or for delivery next month. Hence, policy distinctions are of no aid in ascertaining the type of goods to which the section applies. Perhaps an answer may be found in examining the most puzzling aspect of

45. Because the goods are ready-made they should be easily replaceable on short notice. In addition, $B$ will not be crippled in most cases by any delay which replacement might occasion. See note 99 infra. Finally, the code provisions for damages provide adequate safeguards for the injured buyer. See UCC $\$ \$ 2-713$ to $2-719$. The buyer is forced to take the risk of the seller's insolvency but to some extent he takes this risk in making an offer originally.

46. Under UCC $\$ 2-206, \mathrm{~B}$ could exercise this power by unambiguously indicating what he requires of $\mathrm{S}$ as acceptance of his offer. He may so indicate either by his language or conceivably by a business custom or trade usage. See UCC \& 2-205. Where transactions are hurried and in business shorthand there is little likelihood of contradiction except by custom; however, where the parties deal at their leisure (or possibly by means of forms; see text at note 81 infra) the chances are excellent that an offeror with bargaining power would try to get as much protection as possible.

47. Of course, this reservation would have to be stated unambiguously and personally. It might be argued that notification by the seller should be sufficient as acceptance in all cases; but because of the reasons advanced in note 44 supra and because the buyer should be given freedom as long as the seller will not rely upon a reasonable misunderstanding of the deal which has been suggested to him, the opposite position is taken in the text. 
section 2-206: why is provision made only for acceptance of "goods for prompt or current shipment"? Certainly the common law applied equally to all types of goods. An examination of possible factual situations may be of aid.

Widgets might take six weeks to prepare. Or they might be items which $S$ is producing continuously but will only complete upon receipt of the buyer's order. For example, $\mathrm{S}$ might be manufacturing tables which he will finish in black or white, both of which are commercially desirable. To maintain a minimum inventory, he finishes the tables only when an order is received for a particular color. Parallel problems are presented when $\mathrm{B}$ orders goods which are made only for his order. Thus, B might order for his own manufacturing plant a steam engine which $S$ must produce to specifications. Or Mrs. B might order a set of sterling silver which $S$ will have to cast in a new form. ${ }^{48}$

When $B$ invites $S$ into a business deal involving goods of this nature, it would be unsatisfactory to grant $B$ the power to revoke his offer up to the point at which $\mathrm{S}$ ships the goods. Although B's interest in assurance would be served, $S$ would be left in a precarious position while preparing the goods. If $\mathrm{S}$ has no means of binding $\mathrm{B}$ until he has completed and shipped the goods, the unavailability of alternative buyers should $B$ renege will leave $S$ with little incentive to undertake production of the goods. This fact may of itself force $B$ to relinquish his power by agreeing to recognize a contract prior to shipment. Notwithstanding this possibility, if $\mathrm{S}$ may complete the deal by actually commencing production and simultaneously ${ }^{49}$ notifying $\mathrm{B}$, both parties may be adequately protected. At least this is so when $S$ is providing goods which are entirely made to order: $S$ is assured that once he starts on the goods $B$ will not be able to avoid purchasing; $B$ is notified that $S$ has undertaken to furnish him with the goods and has some assurance that $S$ will complete them because it is probable that it will be less expensive for $S$ to finish than to abandon the work..$^{50}$ This should be the type transaction to which section 2-206(3) applies.

48. There are obviously a host of variations on this theme. Some goods will have ready-made foundations and yet take considerable time to complete; some manufacturers probably make all goods to order even where the operation consumes only a few hours or days. Varying fact situations must be tested individually against the standards set forth in the text.

49. UCC \& 2-206(3) requires that the offeror be notified within "a reasonable time." The analysis advanced in the text indicates that notice should follow the beginning of performance as quickly as possible in order to afford the buyer the utmost assurance possible. It might be argued that as a prophylactic rule the code should demand that notification always follow within a stipulated time period. However, any value in improving business practice would be outweighed by the harsh results which such a rule would frequently dictate.

50. There is always the possibility of supervening events which will induce the seller not to perform despite his expenditure of time and funds in beginning performance. Such events are properly dealt with under other doctrines such as frustration, impossibility, etc. As long as it is more probable than not that the seller will complete the goods when he begins to produce them, offer and acceptance doctrines need not take account of other possibilities. 
Where $\mathrm{S}$ is producing the item continuously and merely finishing it in response to B's order, there is no clear indication in the code as to the proper mode of acceptance. It seems reasonable to assume that $B$ is adequately protected if $\mathrm{S}$ begins performance and notifies $\mathrm{B}$ of that fact. However, because it is almost impossible in this kind of transaction to determine when $\mathrm{S}$ has committed himself to fill the order of a particular purchaser, B gets no more assurance from an assumed commencement of performance than he would achieve from notification alone. ${ }^{57}$ Nevertheless, since sales of this nature are similar to sales of ready-made goods, $\mathrm{S}$ is in a position accurately to estimate his ability to deliver the order. A problem does arise because of the difficulty in this case for $B$ to make the deal binding upon $S$ should $S$ decide not to furnish the goods after beginning performance though prior to notification. ${ }^{52}$ This consideration suggests the final act in binding the parties should be S's mailing an acknowledgment which states his intention to furnish $B$ with the requested goods.

While some situations are adaptable to acceptance by beginning performance followed by notification in a reasonable time, there is no important interest safeguarded by denying the offeree in these instances the ability to conclude a contract by shipment or a prompt promise thereof. As a result it seems more feasible for the code to permit acceptance by promise or shipment in all instances. It further seems reasonable to recognize that in some situations, principally when goods are made to order and are readily attributable to a particular order when in process of preparation, beginning performance can operate as an acceptance if followed shortly by notice to the offeror. In this connection the code would perhaps be of greater value if it provided more specific standards for determining when beginning performance "can be a reasonable mode of acceptance."

Assuming a situation where beginning performance would appropriately operate as acceptance, there remains the question whether subsection (3) should be subject to qualification by buyer's unambiguous indication to the contrary, as subsections (1) and (2) are now similarly qualified. Where goods are prepared for B's order, there is not the same need to protect rapid transactions which demands withholding from $B$ the power to cancel after acceptance. Moreover, while S might have no substitute market for the goods which had been made to B's taste, he can protect himself by refusing to deal unless $B$ waives the right to withdraw after $S$ begins work on the goods. Therefore, $\mathrm{B}$ should be permitted to deny $\mathrm{S}$ the ability to close the deal by notification and beginning performance. Normal notions of freedom of contract should not be subsumed in this case, for doing so might saddle

51. If $S$ is producing the goods at all times subject only to finishing procedures, $B$ may safely assume when he is notified that $S$ would not accept without a basis for determining his ability to perform.

52. This Note has focused upon the buyer's desire to withdraw from the deal. Legal doctrine has chosen the same point-"acceptance"--to determine when the buyer should be able to force the deal upon the seller. See 1 WillisTon, op. cit. supra note $21, \$ 90$. The argument made in the text applies equally if the buyer claims that the seller accepted by beginning performance although he has not yet acknowledged. 
$\mathrm{B}$ with less assurance than he thinks necessary. It seems harsh, however, to permit an offeror a final opportunity to avoid a contract, perhaps after a drop in the market price, when $\mathrm{S}$ has done everything within his powerpossibly at considerable expense-to furnish the goods; therefore, $B$ should not be permitted to require actual receipt. Although the Pennsylvania version of the code does not expressly recognize the right to preclude acceptance by beginning performance, the recently adopted amendments permit contradiction in all cases. ${ }^{53}$

\section{Seller's Shipment of Nonconforming Goods}

The common-law rule which permits acceptance by shipment requires that the goods comply exactly with the terms of the offer ; ${ }^{54}$ this follows from the rule that a response which incorporates terms not contained in the offer is a counter-offer and so a rejection of the original offer ${ }^{55}$ The problem created by this doctrine affects both parties. If $B$ receives goods which upon arrival he discovers to be nonconforming, his use of the goods might be deemed "an acceptance" of the counter-offer, depriving him of a remedy for the breach. On the other hand, if $B$ refuses the goods it may be impossible for $\mathrm{S}$ to discover, unless he knew beforehand, whether the goods are in fact conforming or whether a binding contract was created despite the defect. The new code formulation makes a significant change in contract law :

"Unless the seller states the contrary a shipment sent in response to an order to which it does not conform is an acceptance and at the same time a breach. But a shipment of non-conforming goods offered as an accommodation to the buyer in substitution for the goods described in the order is not an acceptance." 56

53. "(1) Unless otherwise unambiguously indicated by the language or circumstances

(a) an offer to make a contract shall be construed as inviting acceptance in any manner and by any medium reasonable in the circumstances;

(b) an order or other offer to buy goods for prompt or current shipment shall be construed as inviting acceptance either by a prompt promise to ship or by the prompt or current shipment of conforming or non-conforming goods, but such a shipment of non-conforming goods does not constitute an acceptance if the seller seasonably notifies the buyer that the shipment is offered only as an accomodation to the buyer.

"(2) Where the beginning of a requested performance is a reasonable mode of acceptance an offeror who is not notified of acceptance within a reasonable time may treat the offer as having lapsed before acceptance." UCC §2-206, 1957 DRAFT.

54. E.g., Williams v. Emerson-Brantingham Implement Co., 198 S.W. 425 (Mo. Ct. App. 1917); Flatow, Riley \& Co. v. Roy Campbell Co., 280 S.W. 517 (Comm'n App. Tex. 1926); 1 WILliston, op. cit. supra note 21, § 78A. But see Wales Adding Mach. Co. v. Huver, 98 N.J.I. 910, 121 Atl. 621 (1923) (contract completed by shipment by seller of an accommodating substitute which buyer held for ten months).

55. See text at notes 75-89 infra.

56. UCC $\S 2-206(2)$. It is not clear whether this section is designed to apply to shipments of goods for "prompt or current shipment" without notice under \$2-206 (1) (b) or to any shipment of goods without prior notification. The problem is solved by the recent amendment which makes all three subsections subject to "unam- 
The purpose is clear: the draftsmen would remove the deterrent of contractual liability for sellers who want to assist their customers by shipping substitute goods; at the same time, some protection is given the buyer who may unwittingly rely upon a shipment which appears to fulfill the contract and who so acts with regard to the goods that he will be deemed to have accepted them.

Of course, it is no great hardship for the seller-offeree to avoid committing a breach when he ships non-conforming goods: he may insert upon an accompanying packing slip, the invoice or the goods themselves a readily discernible notice that the goods are nonconforming and an accommodation. Whether a shipment of nonconforming goods can be deemed an accommodation without some communication from the seller indicating that the shipment was intended as such is unclear from a reading of the Pennsylvania version of the code. Recent changes, stated to be only a clarification, leave no doubt that the seller must somehow communicate his intention that the shipment be an accommodation. ${ }^{57}$ Although accommodating one's customer is a business practice not to be discouraged by burdening a seller who is trying to aid his buyer, neither should the buyer be weighted with an obligation to determine early whether the goods were intended as an acceptance or as an accommodation..$^{58}$ Certainly, in the absence of notice, the buyer's ability to detect the nature of the response is made most difficult. Conversely, requiring the seller to notify his customer is but a slight inconvenience. The seller's willingness to accommodate no doubt reflects a desire on his part to maintain the goodwill of his customer; accompanying shipment with a notice is consistent with this objective, and a requirement of such notice should not meet with objection. If the goods shipped are nonconforming and the seller fails to furnish the requisite notice, he would be held to a contract and stand in breach thereof.

\section{Acceptance Which Varies From the Offer}

It is a respected common-law contract principle that a reply to an offer constitutes an acceptance only if it complies "exactly with the require-

biguous contradiction." The new section applies to nonconforming goods sent in response to "an order or other offer to buy goods for prompt or current shipment." See note 53 supra. The theory must be that if a sale is arranged which takes a rather long time in the completion the contract will be complete before shipment anyway. It might be wiser to apply this section to all shipments which are made without other response. The Serv-Agen Corporation, seller of processed foods with average shipping delay of one week, uses acknowledgments only for special orders. See letter from the Serv-Agen Corp., to the University of Pennsylvania Law Review, Jan. 31, 1957, on file in the Biddle Law Library. This might well be a general practice in small firms with small secretarial and/or managerial staffs. Only with broader coverage for the "accomodation" section could the proposal made in text at notes 57-58 infra be applied to these firms.

57. See note 53 supra.

58. The buyer might be forced to make a quick decision whether to "cover" (UCC \& 2-712(1)) when he might have to take goods from the seller subsequently, or "accept" (UCC \$ 2-606) the goods and so deprive himself of any remedy for not receiving the goods he ordered. 
ments of the offer, omitting nothing from the promise or performance requested." 59 The obverse proposition, therefore, is understandably strict: "A reply to an offer, though purporting to accept it, which adds qualifications or requires performance of conditions, is not an acceptance but a counter-offer." 60 These coordinate doctrines have frequently been applied to preclude binding agreements when the variance from the offer was no more than formal; strict conformance has been the legal standard if not the business fact. ${ }^{01}$ A contract might not result when the offer but not the acceptance is under seal. ${ }^{62}$ It does not matter that the term which the acceptance varies is legally presumed" rather than explicitly stated. ${ }^{63}$ Nor is it of concern to the courts that "the difference was hardly worth disagreeing about" ${ }^{44}$ or that the offeree's addition is for the benefit of the offeror. ${ }^{65}$

Despite the rigor of the doctrine, several exceptions have been recognized. Parol evidence, in the form of trade usages ${ }^{66}$ or other facts, ${ }^{67}$ may explain an apparent variance. Furthermore, the acceptance is effective

59. Restatemeint, Contracts $\$ 59$ (1932). See also Corbin, op. cit. supra note 20, \$82; WILIISTON, op. cit. supra note $20, \S 77$; see text at note 54 supra.

60. Restatement, Contracts $\$ 60$ (1932).

61. The following cases are cited as a general indication of the formal strictures which are imposed by the courts while businessmen continue to deal in an informal way which is ignorant, or in blatant disregard, of the controlling legal doctrines. The varying importance of the additions made by the offeree have been contrasted. Compare American Smelting \& Refining Co. v. Hyman, 16 F.2d 39 (6th Cir. 1926) (offer quoted basis Louisville and acceptance read f.o.b. the same city; a trade practice indicated a substantial difference in treatment of the buyer) with, Frick \& Lindsay Co. v. Johnstown \& Somerset Ry., $271 \mathrm{~Pa} .536,115$ At1. 837 (1922) (no contract when acceptance changes place of shipment and consignee) ; compare Cohn v. Penn Beverage Co., $313 \mathrm{~Pa} .349,169$ Atl. 768 (1934) (no contract because acceptance stated payment of ten per cent cash, and in absence of statement offer is presumed to be for cash) with, Bokern v. Loud, 108 S.W.2d 1049 (Mo. Ct. App. 1937) (any change of amount of down payment prevents binding contract); compare Hutchinson Baking Co. v. Marvel, $270 \mathrm{~Pa}$. 378, 113 Atl. 433 (1921) (no binding contract where sellerofferee's acceptance stated that the agreement was subject to approval of sample) with, Poel v. Brunswick-Balke-Collender, 216 N.Y. 310, 110 N.E. 619 (1915) (statement in form acknowledgment that receipt must be acknowledged was a counter-offer). But cf. Orr v. Doubleday, Page \& Co., 223 N.Y. 334, 119 N.E. 552 (1918) (request for acknowledgment not essential to inception and operation of agreement-thus distinguishing the Poel case).

62. Featherston v. Reese, 36 Ga. App. 379, 136 S.E. 811 (1927).

63. Cohn v. Penn Beverage Co., 313 Pa. 349, 169 At1. 768 (1934); but see Skinner v. Stone, 144 Ark. 353, 222 S.W. 360 (1920).

64. Cram v. Long, 154 Wis. 13, 23, 142 N.W. 267, 270 (1913).

65. Hutchinson Baking Co. v. Marvel, 270 Pa. 378, 113 Atl. 433 (1921) (no binding contract where seiler-offeree's acceptance stated that the agreement was subject to approval of sample). Nor was it important that the offeree prevented approval by refusing to furnish the sample.

66. "It may be that in the light of the custom of the trade, both of these seeming modifications were not in fact material departures from the original proposal; but all this record shows is that these parties had had business dealings before. . . "Allen v. Simmons, 97 W.Va. 318, 323-24, 125 S.E. 86, 88 (1924); see Jordan v. Walker, 154 Mich. 394, 117 N.W. 942 (1908); Brown v. Norton, 50 Hun 248, 2 N.Y. Supp. 869 (1st Dep't 1888).

67. Cf. Bond v. Wiegardt, 36 Wash.2d 41, 216 P.2d 196 (1950) (letter explaining some of the terms sent by offeree to offeror; explanation indicated a counter-offer was intended). 
if it states only the legal implications of the offer; ${ }^{68}$ but there must be no uncertainty as to these implications ${ }^{69}$ nor doubt about duties which the offeree ascribes to the offeror.70 A "request" of the offeror for better terms or greater indulgence ${ }^{71}$ is not a counter-offer, although the factual distinction between request and condition often is insufficiently articulated. ${ }^{72}$ The offeree may bind the offeror while grumbling at the harshness of his offer, ${ }^{73}$ or while extending him a service as a mere "gratuity." 74

Needless to say, the doctrinal intricacies encouraged litigation. The draftsmen of the code sought to protect business obligations from some of these technicalities, many of which might have been ignored until the commercial setting became a litigative one. ${ }^{75}$ In accomplishing this purpose, a departure was made from the common law approach; it is now possible for a contract to be formed under the code when the offeree's response contains terms different from or additional to those named in the offer. Two essential questions are posed by this section of the code: Has a binding agreement been concluded? If so, what are its terms?

68. Bennett y. Cummings, $73 \mathrm{Kan} .647,85$ Pac. 755 (1906) (request for weighing of goods at destination not a counter-offer because buyer has no duty to accept goods of improper weight) ; Poel v. Brunswick-Balke-Collender, 216 N.Y. 310, 110 N.E. 619 (1915) (statement that acceptance would be a guaranty of prompt delivery not a counter-offer because the acceptance itself was such a guaranty); Magna Oil \& Refining Co. v. Parkville Oil Corp., 96 Okla. 157, 221 Pac. 65 (1923) (seller's addition of shipment by insulated cars not a counter-offer because ICC regulations require such shipment) ; Warner Sugar Refining Co. v. Metropolitan Wholesale Grocery Co., 46 R.I. 158, 125 Atl. 276 (1924) (selier-offeree's addition of F.O.B. N.Y. not a counteroffer because Uniform Sales Act calls for delivery at seller's place of business).

69. Phoenix Iron \& Steel Co. v. Wilkoff Co., 253 Fed. 165 (6th Cir. 1918); CoRBIN, op. cit. supra note $20, \S 87$.

70. See Alexanian v. Fidelity-Philadelphia Trust Co., $151 \mathrm{~Pa}$. Super. 515, 30 A.2d 651 (1943) (no contract where trustee-offeree accepted offer but stated that buyer of trust property would have to make arrangements with broker of previous contract for sale of same real estate at a lower price).

71. Netherwood v. Raymer, 253 Fed. 515 (W.D. Wis. 1918) ; Culton v. Gilchrist, 92 Iowa 718,61 N.W. 384 (1894); Butler v. Foley, 211 Mich. 668, 179 N.W. 34 (1920); Johnson v. Federal Union Surety Co., 187 Mich. 454, 153 N.W. 788 (1915).

72. Compare Swanson v. Linder, 75 N.D. 751, 33 N.W.2d 62 (1948) (no contract because acceptance requested seller-offeree to send deed to offeree's bank) with, Skinner v. Stone, 144 Ark. 353, 222 S.W. 360 (1920) (acceptance effective despite request to have deed sent to offeree's bank because an attempt to close the deal quickly and offeror did not ask for any other closing) and Podany v. Erickson, 235 Minn. 36, 49 N.W.2d 193 (1951) (acceptance effective despite request for abstract of title).

73. Home Gas Co. v. Magnolia Petroleum Co., 143 Okla. 112, 287 Pac. 1033 (1930), 15 Minn. L. Rev. 237 (1930) ; CoRbin, op. cit. sulpra note 20, §84.

74. See De Moss v. Beryllium Corp., $358 \mathrm{~Pa}$.470, 58 A.2d 70 (1948); but see Hutchinson Baking Co. v. Marvel, 270 Pa. 378, 113 Atl. 433 (1921).

75. See UCC $\$ 2-207$, comment 1 . It hardly seems likely that a seller, who receives an offer on the buyer's form and whose form acknowledgment requires notification of its acceptance, needs the assurance of a return by the buyer when the parties have had previous dealings or when the buyer is a member of the trade who is probably familiar with its customs. Contra, Poel v. Brunswick-Balke-Collender, 216 N.Y. 310, 110 N.E. 619 (1915) (statement in form acknowledgment that receipt must be acknowledged was a counter-offer). 


\section{Additional Terms and the Battle of the Forms}

The scheme adopted by the code's draftsmen is to sever the problems surrounding formation of a contract from those of determining its terms. Subsection one of section 2-207, concerned with determining the validity of a purported acceptance, reads as follows:

"(1) A definite and seasonable expression of acceptance or a written confirmation which is sent within a reasonable time operates as an acceptance even though it states terms additional to or different from those offered or agreed upon."

Under this section, if the reply expresses acceptance a contract is consummated. Nonetheless, the code abrogates the common-law requirement of a precise matching of the terms of the acceptance with those of the offer. The merit of the common-law standard for commercial transactions lay in the relatively high degree of certainty which it engendered. The price paid for certainty was occasional unfairness to a party unable to enforce an agreement because of a technicality which might have been unrelated to the other party's reluctance to perform. The code formulation, deemphasizing technicality, is more likely a product of the modern commercial practice of employing forms both for ordering goods and for acknowledging receipt of orders than it is a departure from certainty as a commercial goal. Prior to widespread use of forms, there was little chance of a divergence in purely technical terms; hence the common-law choice emphasized certainty. The basic question is now whether the law should recognize the developing commercial use of forms to the extent that, although technicality will not prevail, businessmen will no longer be able to perform their contractual duties with the degree of assurance which they acquired formerly from the knowledge that the other party was bound.

But to what extent can it be said that there will be a lack of certainty? An order for 1000 black six-inch widgets at nine dollars clearly may not be accepted by an acknowledgment for 900 red one-foot widgets at ten dollars. In fact, it seems clear that the draftsmen did not intend such a response to operate as an acceptance even should the variance involve the color alone. ${ }^{76}$ At common law and under the code such a response would be a counteroffer. The code provision might be interpreted as permitting the formation of a contract when the commercial world would normally recognize its occurrence. Without questioning the desirability of having legal doctrines reflect business practice rather than vice versa, determining the standard actually employed in commercial understanding is a vexing problem. A well-advised firm might understand that at common law a deal may not be enforced by a lawsuit if the acceptance does not conform to the offer. To

76. See UCC $\$ 2-207$, comment 1: "The other situation is one in which a wire or letter expressed and intended as the closing or confirmation of an agreement adds further minor suggestions or proposals such as 'ship by Tuesday,' 'rush,' 'ship draft against bill of lading inspection allowed,' or the like."; TEx. LEG. Councrl, ANALYSIS of Article 2 of the Uniform Commercial Code 41 (1953). 
discard the common-law standard and install that of the business community would have no effect unless the previously well-advised firms in fact ascribe to another notion of when a deal is closed. But to base the legal consequences of commercial transactions upon the notions of men less than welladvised places the cautious at a disadvantage; the complexity of a search for significant trade or community practice demonstrates the uncertainty inherent in the code approach.

If a response with additional terms is operative as an acceptance, a deal might be closed when it is not clear that the offeree intended to close it. Certainly a reply which substantially changes terms of the offer is an equivocal expression of the offeree's assent to a business relationship. Forcing an agreement upon the offeree under these circumstances might be as harsh to him as denying validity to the agreement because of a formal variation when the parties have acted in accordance with the agreement. ${ }^{77}$

This source of unfairness may be mitigated; if section 2-207(1) is designed only to alleviate the difficulties incident to the use of business forms containing standard terms, the old common-law rules would remain in force where agreements are personally negotiated. When the parties are specifically negotiating all terms the offeree is less likely to be willing to be bound to different or additional terms than when he has completed a form with ready-made terms or when a previous agreement is acknowledged by a confirmation form which modifies terms contained in the offeror's order form. ${ }^{78}$ Viewed in this setting the code may be tested by the following hypothetical in which both parties utilize forms incorporating standard terms which conflict in some instances and have no counterpart with each other in others. B orders merchandise from $\mathrm{S}$ and enters on his order form the description of the goods and their quantity, price and delivery date. In response, $\mathrm{S}$ may acknowledge the order on his confirmation form by repeating the data specifically enumerated by $B$. Before remitting this form, $S$ has the opportunity to examine B's standard terms. If $S$ would prefer not to deal with $B$ on these terms, it is not an onerous task to require $S$ to object specifically to the undesirable term or to state generally-by personal indication rather than by printed incorporation on the form-his unwillingness to deal except on his own terms. ${ }^{79}$ In the absence of such an objection by $\mathrm{S}$, his response would operate as an acceptance of B's offer. Should $S$ object to the terms printed on B's order form, his response would not constitute an "expression of acceptance" but would be deemed a counter-

77. Cf. UCC $\S 2-204$ (2) : "Conduct by both parties which recognizes the existence of a contract is sufficient to establish a contract for sale even though the moment of its making cannot be determined."

78. Of course, one party's changing of the terms in a confirmation may cause as much unfortunate difficulty as the practice of adding new terms to an acceptance. See Poel v. Brunswick-Balke-Collender, 216 N.Y. 310, 110 N.E. 619 (1915). It is possible that here the party receiving the confirmation might not want to deal with the extra term, but he should not be able to contend that because the extra term was added he may escape a deal which does not include the new term despite the fact that he had already agreed to such a deal. For an attempt to reach the result recommended in the text which is unnecessarily complex, see the formulation of $\$ 2-207$, note 81 infra.

79. $C f$. text and notes 108-10 infra. 
offer which $B$ might accept. Should $S$ change any of the non-standard provisions in B's order, this lack of agreement would preclude an acceptance.

If the application of section 2-207 is limited to those instances in which printed forms are used, two evils are lessened: the lack of certainty as well as the ability, otherwise magnified because of current business practice, to escape agreements with impunity on wholly technical grounds. When no form is used, the common-law emphasis on certainty even to the prejudice of some nonetheless diligent businessmen continues to have merit. But this construction of the present code section is not warranted by the intentions of the draftsmen. Accordingly, the section should be redrafted and specifically limited to those instances in which the additional or different terms are printed on the offeree's standard form. Apparently the original formulation of this subsection has not met with unanimity among the expert advisors. Although it is currently the law in Pennsylvania, the original American Law Institute draft has by now been altered twice. ${ }^{80}$ The latest change re-adopts the original approach but adds the important qualification, "unless acceptance is expressly made conditional on assent to the additional or different terms." 81

Under either formulation a lawyer may advise his clients to incorporate in their printed acknowledgment forms as many conditions of sale as are

80. See UCC § 2-207 (Supp. 1 1955); UCC \$2-207, 1957 DRAFT.

81. UCC $\$ 2-207(1), 1957$ DRAFT. There is some evidence that the same freedom for the offeree was intended in the original formulation: ". . any additional matter contained either in the writing intended to close the deal. . falls within subsection (2) and must be regarded as a proposal for and added term unless the acceptance is made conditional on the acceptance of the additional terms." UCC \$ 2-20\%, comment 2. (Italics added.) The following proposal was made in UCC § 2-207 (Supp. 1 1956):

"(1) Where a contract for sale is concluded by word of mouth and terms additional to or different from those of the agreement are included in the written confirmation of one party or of each, then the oral agreement controls. This provision is subject to the statute of frauds (Section 2-201) and to the provisions on final written expression (Section 2-202), and to the operation of subsection (6).

"(2) Where a written offer is not accompanied by form clauses a seasonable and definite expression of acceptance operates as an acceptance even though it states terms additional to those offered unless the acceptance is explicitly made conditional on assent of the offeror to any additional term. Any additional term is to be read as a proposal for addition to the contract.

"(3) Where a written offer of one party is accompanied by form clauses prepared by the other party the clauses are incorporated into the offer unless they are manifestly unreasonable.

"(4) When a written offer is accompanied by form clauses prepared by the offeror, a definite and seasonable expression of acceptance operates as an acceptance even though it contains form clauses additional to or at variance with those of the offer, unless either

(a) the offer conspicuously makes its acceptance conditional on the offeree's agreement to any specified one of its form clauses or to all of them; or

(b) the expression of acceptance conspicuously makes its own operation conditional on the offeror's agreement to any specified one of its form clauses or to all of them.

"(5) Even though by reason of such conspicuous conditions as are described in subsection (4) a contract fails by reason of such exchange of writings, yet conduct by both parties which recognizes the existence of an agreement about the subject-matter is sufficient to establish the fact of agreement. In such case the terms of the particular agreement consist of those terms on which the writings of the parties agree, together 
consistent with the continued good will of their customers; with one possible exception, ${ }^{82}$ the inclusion of extra terms will not prevent the formulation of a binding contract even if some of the terms are not considered part of it. The offeree's form might expressly provide that "acceptance is conditioned upon your agreement that the terms and conditions stated on the face and printed on the back hereof shall constitute the sole terms of this order." ${ }^{83}$ Should that condition be permitted to prevent formation of a contract? It is doubtful that such a clause should be given effect without the offeror's specific assent to the new terms, but such a result might be accomplished by including in an acknowledgment form the following clause: "If this acknowledgment contains terms additional to or different from the PURCHASER's order, it shall be effective as an acceptance only if such terms are included in the agreement and they shall be so included if not objected to in writing within ten (10) days from the date hereof." 84 In determining whether either of these conditions should be enforced, the best approach is thorough analysis of the business motives which prompt the offeree to require express assent to additional terms. If offerees seldom need the assurance of specific assent, there is no compelling reason to permit them this means of either harassing their offerors into responding or avoiding transactions when convenient because assent was not forthcoming.

The offeree would normally wish to require assent to the terms of his acknowledgment when he considers inclusion of the proposed additional terms essential to his entering the transaction. As previously indicated, the offeree's insistence on his own terms, when communicated specifically rather than by a printed statement on the form, would present a counteroffer and prevent the formation of a binding contract.85 It is arguable that if an offeree is permitted to counter-offer by this method, his incorporation of the assent condition in his printed form should be equally valid; but there is reason to reject this contention.

Some offerors may be so willing to abide by standard provisions that they would rely upon the apparent acceptance on the face of the form without examining the fine print on the acknowledgment for some time after receipt-possibly beyond a reasonable time for acceptance of the counter-

with any supplementary terms incorporated under either the next subsection or any other provisions of this Act.

"(6) Between merchants an additional term which has not been the subject of specific negotiation and which in good faith is added to a written expression or confirmation of acceptance becomes part of the contract unless it is at variance with a term of the offer or unless notification of objection has been given in advance or is given within a reasonable time after notice of the additional term is received or unless the additional term is manifestly unreasonable."

82. See text and note 76 supra.

83. Sales order form of Aluminum Company of America (Pittsburgh, Pa.) sent to the University of Pennsylvania Law Review, on file in the Biddle Law Library.

84. Acknowledgment form of a Pennsylvania corporation sent to the University of Pennsylvania Law Review, on file in the Biddle Law Library. The effect of this condition could be avoided if the buyer includes in his order form a clause objecting to all additional terms. See text at notes 107-08 infra.

85. See text at note 79 supra. 
offer. Furthermore, while the delay and expense incident to requiring assent from the offeror is justified when the offeree, upon examination of the offeror's terms, is not wholly satisfied, a preconception of dissatisfaction alone should not warrant the burden. It is true that the offeree might desire the offeror's assent as security against a later dispute; the offeree would be more likely to seek this assurance when his additional terms are not so usual that the offeror could be expected to have knowledge of them. ${ }^{86}$ This consideration would be most important when the offeror is a person with whom the offeree has not previously transacted business. Even so, the extra-legal impact of business mores and practice sufficiently insures the offeror's willingness to perform. ${ }^{87}$ The offeree might prefer to forego the security of assent rather than impose upon or antagonize new customers or suppliers or take the risk that the offeror might end the business relationship by refusing to accept the "counter-offer." Moreover, if the offeree's response is conditioned on assent by the offeror, neither are legally bound in the interim. ${ }^{88}$ This factor would probably be decisive in negating the value of such a condition where business transactions are rapid because of the need for quick merchandise turnover or the risk of market fluctuations. In any event, rules providing for the incorporation of proposed additional terms can satisfy the parties' need for certainty as to the terms and for fairness as to the incorporating procedure, while burdening them only lightly. Consideration will be given such rules in a later section.

Yet what the businessman would choose in a particular situation and what the law should permit are not necessarily identical. Denying to businessmen for any reason the right to avoid obligation is a severe imposition upon individual autonomy in business affairs; it should be warranted only by the danger of a significant evil. It is important to note the slight probability that an acknowledgment form will contain such substantial modifications of the offer that the offeror would abandon the deal rather than accept these terms or that the offeree would refuse to deal without them. ${ }^{89}$ The general

86. There would seem to be an inverse relationship between the operation of $\$ 2-207(2)$ and the offeree's desire for specific agreement. See text at notes 100-11 infra. As the offeree becomes less sure that the code will guarantee the extra terms included in the acceptance, the more likely it is that he will demand assurance. For instance, the seller's desire to receive assent to a disclaimer of any consequential damages clause (see UCC $\$ 2-715$ ) would increase if this is such an abnormal agreement in the trade that it would be taken to "materially alter" the contract.

87. See text at note 89 infra.

88. See text and note 51 supra. This is subject to the operation of UCC § 2-204. See text at note 107 infra.

89. If the offeree who responds by form acknowledgment is permitted to require specific assent it should only be allowed by personal statement of the requirement. See text at note 84 sippra. There would seem to be much more chance of either situation described in the text when all of the terms are specifically negotiated. Of course, the so-called battle of the forms can occur when no forms are used. Many of the cases cited at notes 61-74 supra involved changes made to the offer personally by the offeree or his agent. Yet the battle will normally occur when the buyer sends an order on his form and the seller responds on his own form. It is cured if seller's salesman takes an order on seller's form; but if as well the buyer sends one of his order forms, a court would have to determine which constituted the "offer" for purposes of $\S \S$ 2-207 (1) and (2). 
commercial practice of adhering to terms quoted in the acknowledgment must be taken into account. In response to a questionnaire, answering businesses indicated almost uniformly their willingness to be bound by statements in their suppliers' acknowledgment forms. This practice itself affords basis for denying offerees the right to demand specific assent as a condition to a binding contract. Businessmen should not be enabled to escape in court, commitments which they would have observed as a matter of course but for the litigation. Despite the fact, then, that no formulation can be expected to fit perfectly an infinite variety of business situations, all these factors indicate that section 2-207 will operate more efficiently if printed "assent" conditions are denied effect.

\section{"Different" Terms and the Doctrine of Mistake}

It is a well settled common-law rule that "if either party knows that the other does not intend what his words or other acts express, this knowledge prevents such words from being operative as an offer or an acceptance." ${ }^{90}$ This is but one in a series of contract doctrines which determine relationships and remedies between parties when an innocent "mistake" disrupts a business deal. Mistakes in the negotiation of a contract can take many forms-the offeree might understand the offer incorrectly; ${ }^{91}$ the offeror might express limself erroneously; ${ }^{92}$ the two parties might refer to separate things with identical names; ${ }^{93}$ or a clerical error might be made by either or both parties.94 The last problem, to be expected with some frequency in rapid commercial transactions which lack personal contact, presents challenging problems in code doctrine.

The difficulties may aptly be examined against the facts of the recent case of United States v. Braunstein.95 Defendant bid for government surplus raisins in twenty-five pound boxes at ten cents per pound. In accepting the bid the Government by a clerical error restated the price as ten cents per box. Despite the Government's subsequent telegram explaining the mistake, which obviously was in defendant's favor, defendant refused to accept and pay for the raisins. The Government sold the raisins to

90. Restatement, Contracts $\$ 71$ (c) (1932). "A says to B, ' $T$ offer to sell you my horse for $\$ 100$. $^{\prime} B$, knowing that $A$ intends to offer to sell his cow, not his horse for that price, and that the use of the word 'horse' is a slip of the tongue, replies, ' $I$ accept.' There is no contract for the sale of either the horse or the cow." Id. at $\$ 71$, comment a, illustration 2 .

91. See, e.g., Neel v. Lang, 236 Mass. 61, 127 N.E. 512 (1920), or 3 CorBIN, op. cit. supra note $20, \S 599$.

92. E.g.; Embry v. Hargadine, McKittrick Dry Goods Co., 127 Mo. App. 383, 105 S.W. 777 (1907).

93. E.g., Raffles v. Wichelhaus, 2 Hurl. \& C. 906, 159 Eng. Rep. 375 (Ex. 1864).

94. See 3 Conbin, op. cit. supra note $20, \S 609$; cf. Vickery v. Ritchie, 202 Mass. 247,88 , N.E. 835 (1909) (def rauding agent caused builder to promise to erect building for one price and owner to pay another).

95. 75 F. Supp. 137 (S.D.N.Y. 1947), 33 Minn. L. Rev. 73 (1948). 
another buyer at a lower price and sued defendant for the difference. In denying relief under the common law, the court held that when a purported acceptance repeats the terms of the offer the offeree assumes the risk of his own clerical error in repetition. No effect was given to the undisputed evidence of the Government's intent as expressed in the later communication. ${ }^{06}$

An attorney cannot effectively prevent mistakes in responses, but he can advise his client as to the steps which should be taken to avoid rendering them costly. It seems advisable for an offeree always to state explicitly that he is making a counter-offer when he recommends a price or quantity change to the offeror. Insofar as it is commercially reasonable, the offeree should accept without repetition of terms; if it is necessary to repeat, either on form acknowledgment or otherwise, the offeree should include a statement that his acceptance contemplates the original quantity and price unless the contrary is plainly indicated.

Although the lawyer's counseling task is clear, the problem may still be open to question as a matter of legislative wisdom. There seems no good reason to permit avoidance of binding contracts merely because one who has already agreed to terms tries to, or by mistake does, change the statement of them in subsequent confirmations. But other considerations are present, especially when the parties are dealing at a distance and using business shorthand. If the offeror receives a reply which varies the price or quantity of goods, the offeree's statement is equivocal; the offeree may have made a clerical error or he may in fact be seeking another quantity or price and be unwilling to agree to the offeror's figures. In the latter event, it seems harsh to impose agreement upon the offeree.

Ideally, a rule could be formulated which would adapt itself to changing fact situations. Where the parties are at a distance, the goods nonindividualized and the market fluctuating, the offeree should be able to correct his mistake and make a binding contract as long as the offeror has not reasonably relied to his detriment upon an apparent rejection by counteroffer. If the market were not one in which speed is essential, the offeror might be required to investigate for possible mistake or to determine whether the offeree contemplated a sale as originally stated. A system which could achieve the necessary flexibility would probably be extremely complex and invite litigation. A statutory framework must be formulated which will avoid harshness both to the offeree who does not intend a deal and to the offeror who might reasonably rely upon the offeree's response as a counteroffer.

96. Accord, Jacob Johnson Fish Co. v. Hawley, 150 Wis. 578, 137 N.W. 773 (1912) (offeree's telegram read "Terms accepted, engage Capt. Garland, writing."). An alternative ground is available in cases of this sort: at common law, as a corollary to rules already examined, there is no contract if the offeror reasonably misinterprets an acceptance with a request as a counter-offer. "In such a case, the offeror is not bound, although there is a true meeting of the minds." 3 CoRBIN, op. cit. supra note 20 , $\S 599$, at 366 . Brannstein did not use this method because by way of dictum the court stated that the defendant could not have accepted the Government's counter-offer. 
Two provisions of the code seem broad enough to deal with this problem. Section 2-207(1) states: "A definite and seasonable expression of acceptance . . operates as an acceptance even though it states terms . . . different from those offered. . . ." Section 2-204(1) provides that a "contract for sale of goods may be made in any manner sufficient to show agreement." Giving broad scope to either of these provisions, a court could conclude that a contract is formed even though there is a material misstatement in the alleged acceptance if a reasonable man would understand that the offeree intended to accept the offeror's terms.

Applying this principle to the Braunstein case, it appears that no reasonable man could doubt the offeree's intent to accept the offer, since the reply was at a price more favorable to the offeror than was his original offer and the offeree's subsequent telegram explained the discrepancy. Utilization of the code in this case would thus seem to obviate an otherwise harsh result, but similar application in other instances could well upset the normal functioning of business affairs by introducing an inordinate degree of uncertainty. It might be wiser to ignore the appeal of the offeree's position in a Braunstein situation in the interest of the majority of commercial transactions. Previous discussion has indicated that section 2-207(1) should be restricted in recognizing a response as an acceptance to cases where printed business forms are used and the particularized provisions of the individual order are not varied by the reply.

Section 2-204(1), however, need not be so limited. On its face, this provision changes the result in the Braunstein case whether or not there is the clear evidence of intention which the second communication manifested. Although section 2-204(1) seems to have been a statement of policy for recognition of informal contracts rather than a restrictive rule by which they should be tested, ${ }^{97}$ there is no express limitation on a court's application of the section when the facts are such that agreement is beyond question despite a misstatement. The potential expansion of this provision for use in solving indeterminate situations is nonetheless disconcerting. Therefore, although it seems desirable for the Bronustein result to be changed, and section 2-204(1) is available to accomplish that end, it may be better to re-draft that section or add a new provision to deal specifically with clerical mistakes in the offeree's reply.

A new provision might adapt to this problem the common-law approach to an offeree's "snapping up" an offer when he had reason to know the terms were mistaken. ${ }^{98}$ An alternative would be to require the offeror, when the response contains a discrepancy, to notify the offeree of the possible mistake, and allow the offeree to accept the original offer only if there has been no reasonable and substantial change in position by the offeror during the intervening period. This alternative may well be the best; it

97. "Subsection (1) continues without change the basic policy of recognizing any manner of expression of agreement, oral, written or otherwise. The legal effect of such an agreement is, of course, qualified by other provisions of this Article." UCC $\S 2-204$.

98. See text and note 90 supra. 
would continue the Brannstein rule, but neither party would be placed completely at the mercy of the other. ${ }^{99}$

\section{Battle of the Forms: The Aftermath}

At common law additional terms included in an acceptance by the offeree were, without further action by the offeror, inoperative. If the acceptance were conditional, the offeror could accept the counter-offer and the terms of the contract would be those stated by the offeree in his original response. If the additions were merely "requests," the offeror quite obviously might disregard them in performing the bargain. The code, by virtue of the decision to recognize contracts between parties without regard to the presence of new terms in the acceptance, had to make provision for such terms. The problem was met by section 2-207(2) in the following manner:

"(2) The additional terms are to be construed as proposals for addition to the contract and between merchants become part of the contract unless they materially alter it or notification of objection to them has already been given or is given within a reasonable time."

The code need cause an offeror who is not a "merchant" no fear that his contract of sale will be consummated with terms of which he was unaware when he instituted negotiations. Any additional terms which the offeree proposes will only result in "proposals for addition." The reason for the distinction between merchants and others, while not discussed by the draftsmen is manifest: non-merchant buyers and sellers, since they do not transact business regularly, are not to be required in handling an individual transaction to make unnegotiated adjustments because of last minute changes introduced by those with whom they deal. ${ }^{100}$

Apparently a merchant need not be a large-scale entrepreneur; rather he is defined as:

“. . . a person who deals in goods of the kind or otherwise by his occupation holds himself out as having knowledge or skill peculiar to the practices or goods involved in the transaction or to whom such knowledge or skill may be attributed by his employment of an agent or broker or other intermediary who by his occupation holds himself out as having such knowledge or skill." 101

99. There are few emergency situations in which production or distribution requirements would not permit time for notification to the offeree. Even small businesses generally keep inventory levels of staples sufficient for operation until a response is received. See letter from Serv-Agen Corp. to the University of Pennsylvania Law Review, Jan. 31, 1957, on file in the Biddle Law Library. The offeree may still use a method of indicating unambiguously that he has intended a counter-offer. The solution to the problem does put some heavy emphasis upon court participation in determining the nature of the change in position. However, the rule gives each party definite duties and a bargaining issue which is easily translated into factual terms.

100. This principle would seem to be corollary to the argument made earlier that § 2-207 should be applied to force a contract only upon those parties who use form offers and acknowledgments. See text at note 78 silpra.

101. UCC \& 2-104. 
The draftsmen expressly state that for purposes of section 2-207 "almost every person in business would . . . be deemed to be a 'merchant' . . . since the practices involved in the transaction are non-specialized business practices such as answering mail." 102 Certainly it seems that very few transactions of a similar kind would be necessary to make the offeree and the offeror merchants. The term is intended to apply as well to those who "deal" as to those who have "apparent knowledge." A garage mechanic sells a car to a used car dealer for the second time; is he then one who deals? Or, if not, does he have sufficient knowledge of cars to be a merchant as to the particular car? The problems in the application of the term "merchant" to section 2-207 may only be suggested here.

Between "merchants" all of the acceptance terms will become part of the contract unless "they materially alter it." The comment to section 2-207 gives examples of terms which alter the contract materially and otherwise. Any attempt by the offeree to negate standard warranties would be a material alteration. ${ }^{103}$ It seems likely that any term which has not been contradicted by the offer and for which provision is made in another section of the code in the absence of contradiction, will not be a material alteration. ${ }^{104}$ Between these poles, however, the offeree cannot be assured of his power to enforce an additional term to which the offeror has not objected. The comments emphasize the factors of surprise and hardship in applying the material alteration test. ${ }^{105}$ Certainty can hardly have been the primary aim when the comment illustrates a material alteration as "a clause requiring that complaints be made in a time materially shorter than customary or reasonable"; ${ }^{106}$ or when an immaterial alteration would be a "clause setting forth and perhaps enlarging slightly upon the seller's exemption due to supervening causes beyond his control. . . ." 107

Because of this uncertainty, it may plausibly be argued that the code should make the contract binding despite the additional terms and without including any of them. But this solution could substitute for the present uncertainty litigation aimed at establishing as a course of dealing or usage of trade the adoption of additional terms despite their legal unenforceability. In addition, it does not recognize that businessmen in fact will continue to observe additional terms. Nevertheless, the business practice of adopting these terms is not sufficient reason to make their adoption compulsory. To require the offeror's adoption of all terms added by the offeree could encourage offerees to take unfair advantage of their customers.

102. $I d$. at comment 2 .

103. UCC \& 2-207, comment 4.

104. Many sections of the code are designed to supplement the specific provisions bargained for by the parties. If the parties do not include them, the provisions would be included by operation of the statute. Therefore, the offeree's addition would be immaterial; the offeror would have been bound by the provisions anyway. See, e.g., UCC $\$ \S 2-305,2-312,2-314$. See also text at note 68 supra.

105. See UCC § 2-207, comment 4.

106. Ibid. (Emphasis added.)

107. UCC § 2-207, comment 5. (Emphasis added.) 
Another alternative, already recognized by section 2-207(2) as a means of avoiding additional terms, is possible. All terms added by the offeree might be made binding except those to which specific objection is made by the offeror. The adoption of this alternative would insure that both offeror and offeree have equal bargaining strength should there be a conference concerning terms prior to the offeror's objection. In addition, this solution could be available for all persons without the difficulty of applying the "merchant" dichotomy. Even those businessmen who deal without order forms and are bound by an acceptance which contains additional terms might be required to contact their offerees once more if they do not plan to abide by any of the new terms. Although a slight burden is placed upon the offeror, he can rely upon a binding contract under the original terms as soon as he sends objection; the offeree in accepting the offer and stating the additional terms may be presumed to take into account the possibility that the offeror might object.

Under the present formulation, the most obvious method for a merchant-offeror to prevent the inclusion of additional terms is to notify the offeree of his objection immediately after he is given opportunity to review the acceptance and his business needs. ${ }^{108}$ The code also permits the merchantofferor to register objection in advance by enclosing in his offer a disclaimer of intention to abide by any additional terms. ${ }^{109}$ Although this provision affords flexibility for business choices, it also enables offerors to avoid operation of the code section merely by incorporating a disclaimer upon their order forms, rather than by reflecting and bargaining upon each additional proposal. Since business practice probably encompasses adherence to additional terms, ${ }^{110}$ the best statutory approach would prevent their foreclosure by the offeror prior to his consideration of the offeree's additions to the contract. ${ }^{111}$

108. The code permits notification within a "reasonable time," probably because of the hardship that would be worked the offeror by forcing him to make immediately a business decision which would ordinarily be postponed until some future time. But practices of merchants should be so standardized that they will be able to know upon receipt of the acceptance whether they are willing to abide by the additional terms.

109. See purchase order form of Midvale-Heppenstall Co., Phila., Pa., sent to the University of Pennsylvania Law Review, on file in the Biddle Law Library: "This purchase order constitutes an offer on the part of the Midvale-Heppenstall Company upon the terms and conditions and at the prices stated herein and, upon acceptance by the Vendor, becomes a contract constituting the entire agreement between the parties. The Terms and Conditions of this order supersede any conflicting Terms and Conditions in Vendor's proposal." See also purchase order of Stratford Furniture Corp., Souderton, Pa., sent to the University of Femsylvania Law Review, on file in the Biddle Law Library: "This order must be filled according to written and printed instructions stated hereon as to description, prices and terms." The newest formulation only makes the alternatives more explicit. See UCC $\$ 2-207$ (2) (a), 1957 DRAFr.

110. See text at note 89 sipra. It is probable that objection will not be presumed from the fact of conflicting terms alone. See UCC $\$ 2-207$, comment 6 , which discusses conflicting terms only in relation to confirmations of existing contracts.

111. Of course, the offeror could uniformly send out a form letter as soon as acceptance is received, but there would be little incentive for him to do this. As long as the offeror knows that he cannot avoid the terms in advance, he will probably consider the additions. If after this opportunity he is subsequently held to terms which materially alter the bargain, there is no reason to pity his plight. 


\section{CONCLUSION}

This Part has considered the code's application to several common commercial situations. Suggestions have been made to adjust code doctrines so as further to afford the utmost freedom for the parties consistent with the certainty necessary for rapid transaction of business affairs. An attempt has been made, in considering the point at which the buyer-offeror should no longer have the ability to prevent the offeree's power of acceptance, to balance the need of the buyer for assurance of delivery with the seller's need for security in production of specified lots. Other formation problems examined required that duties be placed on one party or the other. Burdens have been recommended for the seller in treating shipments of nonconforming goods, recognizing that a slight burden will be greatly outweighed by the concomitant prevention of uncertainty to the buyer. When the offeree asserts additional or different terms and does not wish to be bound without such terms, a burden upon him of specific notation has been suggested, and a corresponding burden of notation is urged upon the offeror where the offeree seeks to prevent the inclusion of alternative terms in the contract. In all these situations there is a common thread: the shaping of legal rules to fit market custom and the legislative ordering of commercial affairs only in those instances where the need is apparent and the method convenient.

\section{PART II. TENDER OF NONCONFORMING GOODS- BUYER'S DUTIES UPON RIGHTFUL REJECTION}

At times goods shipped in response to a contract or to the buyer's order will not conform thereto: the buyer then has the option to accept or reject such goods. His decision will be affected by several considerations, including the importance of the non-conformity, the state of the market, normal practice in the trade and the buyer's relationship to the seller. It is possible that the seller, by renegotiating the price may induce the buyer to retain the goods when the buyer might otherwise have declined to keep them.

Should the buyer elect to reject ${ }^{112}$ the seller's tender of performance, the code requires that the buyer take certain measures ${ }^{113}$ apparently for the prime purpose of safeguarding the value of goods and the seller's interest therein..$^{114}$ The buyer's duties vary with the perishability of the goods and with his status as a merchant or non-merchant. His own interests are

112. For a discussion of when a buyer may reject under the code see Honnold, Buyer's Right of Rejection, 97 U. PA. L. Rev. 457 (1949).

113. UCC \$§ 2-601-2-604.

114. See UCC $\$ 2-603$, comment 1; UCC \& 2-604, comment. 
protected by allowing him reimbursement for reasonable expenses in storing or selling the goods.

\section{Buyer's Preliminary Duties Upon Rejection}

Assume that shoe store B contracts to buy ten dozen dress shoes from distant manufacturer S. After receipt of S's shipment B discovers that S has delivered ten dozen work shoes.

If $B$ intends to reject the shipment he must inform $S$ within a reasonable time after receipt of the goods. ${ }^{115}$ Moreover, where the defect could be cured by the seller if promptly disclosed, ${ }^{110}$ or where between merchants the seller requests a full statement of all defects, ${ }^{117}$ the buyer must state the particular defect on which his right to reject is based; failure to "particularize" will be deemed a waiver of the defect.118 While the code contains no express criteria to determine when the defect is properly "particularized" the context of the provision suggests that notice need merely be specific enough to permit the seller to correct the defects.

Aside from giving notice, B's only immediate duty is to hold the goods with reasonable care for a time sufficient to permit $S$ to remove them ${ }^{119}$ or to instruct buyer of some other manner of disposition. ${ }^{120}$ If the buyer made any payment on the price he may give notice to the seller of his intention to resell the goods and withhold from the proceeds an amount up to the value of his claim. ${ }^{121}$ The requirement of reasonable care should present little difficulty to the buyer in the ordinary case, such as B in the shoe hypothetical. In some instances, however, the buyer may be considerably inconvenienced by a duty to care for the goods. For example, assume that $J$, owner of a small retail jewelry shop, orders ten aluminum window screens from $S$ for installation in J's store. If $S$ wrongfully delivers ten very large plate glass windows, which $J$ properly rejects, $J$ may be

115. UCC \& 2-602(1). At common law and under the Uniform Sales Act the rejecting buyer had to notify the seller but not return the goods. See 3 WrLriston, Sales $\$ 497$ (3d ed. 1948); Uniform Sales AcT $\$ 50$.

116. UCC $\S 2-605$ (1) (a). Section 2-605 is entitled "Waivers of Buyer's Objections by Failure to Particularize."

117. UCC § $2-605(1)(b)$.

118. UCC \& $2-605(1)$.

119. UCC $\S 2-602(2)$ (b). The text of that subsection follows: "If the buyer has before rejection taken physical possession of goods in which he does not have a security interest under the provisions of this Article (subsection 3 of Section 2-711), he is under a duty after rejection to hold them with reasonable care at the seller's disposition for a time sufficient to permit the seller to remove them. . . (Emphasis added.)

120. UCC § 2-603(1). UCC § 2-602(2) (a) provides that subject to $\$$ 2-603 and 2-604 ". . .any exercise of ownership by the buyer. . . is wrongful as against the seller ...." Acts of ownership are for example the buyer's retention of the goods more than a reasonable time without notifying the seller, of rejection, mortgaging the goods, depositing the goods in a warehouse for buyer's account and paying seller the price, and a resale of the goods. See 1 WiLLISTON, SaLEs $\$ 77$ (3d ed. 1948). This rule is a codification of the common law and the Uniform Sales Act. See 3 Williston, SALES $\S 481$, text at n.10 (3d ed. 1948); UNIFORM SALES ACT $\$ 48$.

121. UCC \& 2-711(3). 
seriously handicapped in caring for the goods, considering the complications of meager storage space and the bulk and fragile nature of the plate glass. Nevertheless, the burden seems justified as a means of conserving property and economic value. Upon receipt of B's notice of rejection, S may elect to remove the goods, ${ }^{122}$ send instructions requesting $B$ to dispose of them or possibly do nothing. Should S decide to remove the goods, B's only obligation would be to hold them with due care for a reasonable time until S acts. ${ }^{123}$ The other alternatives, however, present problems which vary according to the type of goods and the buyer's "merchant" status. The code, extending beyond prior law, ${ }^{124}$ requires that a "merchant buyer" follow any "reasonable instructions" of the seller when the latter has no agent or place of business at the market of rejection. ${ }^{125}$

\section{Duties of a Merchant Buyer}

"Merchants" are distinguished by the code from other buyers and sellers for a number of purposes including the duties placed upon them with regard to warranty, ${ }^{126}$ risk of loss ${ }^{127}$ and good faith. ${ }^{128}$ Furthermore, the code is so drafted that whether one is considered a "merchant" depends upon the specific purpose in question, i.e., one can be considered a merchant for the requirement of good faith but a non-merchant with respect to a warranty. A "merchant" is considered a professional in dealing in the type of goods and/or practices involved. ${ }^{129}$ Knowledge of either the goods or the practices is sufficient to constitute buyer a "merchant" for the purpose of determining buyer's duty to follow seller's instructions. Thus, in the shoe store and jewelry shop hypothetical cases, while both buyers are familiar with elementary business practices, their expertise differs with respect to

122. UCC $\S 2-602(2)(b)$. The goods technically belong to the seller.

123. Ibid.

124. See note 115 supra.

125. UCC $\S 2-603(1)$. The text of $\S 2-603$ follows: "(1) Subject to any security interest in the buyer (subsection 3 of Section 2-711), and when the seller has no agent or place of business at the market of rejection a merchant buyer is under a duty after rejection of goods in his possession or control to follow any reasonable instructions received from the seller with respect to the goods and in the absence of such instructions to make reasonable efforts to sell them for the seller's account if they are perishable or threaten to decline in value speedily. Instructions are not reasonable if on demand indemnity for expenses is not forthcoming. (2) When the buyer sells goods under subsection (1), he is entitled to reimbursement from the seller or out of the proceeds for reasonable expenses of caring for and selling them, and if the expenses include no selling commission then to such commission as is usual in the trade or if there is none to a reasonable sum not exceeding ten percent of the gross proceeds. (3) In complying with this section the buyer is held only to good faith conduct and good faith conduct hereunder is neither acceptance nor conversion nor the basis of an action for damages."

126. UCC \& 2-314(1).

127. UCC $\$ 2-509(2)$.

128. UCC $\$ 2-103(1)(b)$.

129. UCC \& 2-104(1) states: "Merchant means a person who deals in goods of the kind or otherwise by his occupation holds himself out as having knowledge or skill peculiar to the practices or goods involved in the transaction or to whom such knowledge or skill may be attributed by his employment of an agent or broker or other intermediary who by his occupation holds himself out as having such knowledge or skill." 
the rejected goods. The shoe retailer whose purchase was for resale has professional knowledge of the goods in issue and their handling; the purchase and sale of shoes is his business. However, the jeweler ordered goods for consumption and normally deals in small quantities of rather delicate items; he is probably ignorant of plate glass qualities and its crating and shipping. In spite of his owning a store, the jeweler probably lacks sufficient knowledge to be deemed a "merchant" with regard to the plate glass. Hence, unlike the shoe retailer, the jeweler need not follow his seller's instructions on disposition of the rejected goods. This conclusion seems in accord with the goal of effecting a rational balance between inconvenience to the buyer and the possibility of disproportionate loss to the distant seller.

Interpretation of the correlative concept of "reasonable instructions" 130 requires a similar balancing of inconvenience to the buyer against undue loss to the seller. The code provides only that "instructions are not reasonable if on demand indemnity for expenses is not forthcoming." 131 Although buyer has a common-law right to recover expenses, ${ }^{132}$ the right to payment would not arise until after the expenditure is incurred. The code, however, alleviates the buyer's duty to follow instructions if he feels insecure about reimbursement and the seller offers no indemnity upon the buyer's request. If instructions are not forthcoming from the seller within a "reasonable time," a merchant buyer possessed of rejected goods which are perishable or which threaten to decline in value speedily must make reasonable efforts to sell the goods; ${ }^{133}$ if the goods are not of such character he may store, reship or resell them. ${ }^{134}$ The indefiniteness of the code's waiting period may be vexatious for many buyers: premature disposition will result in potential liability, while prolonged retention may be inconvenient and also result in potential liability. ${ }^{135}$ Presumably the draftsmen feared that a specific time period would be the source of an even greater hardship to the sellers. Whether or not such an assumption is justified, the waiting period as presently stated must be determined by the circum-

130. UCC \& 2-603(1).

131. Ibid.

132. At common law the buyer had a lien for expenses even if no part of the price was paid. See Barnett \& Co. v. Terry \& Smith, 42 Ga. 283 (1871) (shipping expenses); Truman's Pioneer Stud Farm v. Hansen, 108 Kan. 717, 196 Pac. 1087 (1921) (feed, care and expenses of the sale); Isidore Strauss \& Sons v. National Parlor Furniture Co., 76 Miss. 343 (1898) (the buyer is entitled to reasonable insurance and storage charges on the resale) (dicta); Little Rock Grain Co. v. A. Brubaker \& Co., 89 Mo. App. 1 (1901) (freight); Messmore v. New York Shot and Lead Co., 40 N.Y. 422 (1869) (freight).

133. UCC \$ 2-603(1).

134. UCC \$2-604. The text follows: "Subject to the provisions of the immediately preceding section on perishables if the seller gives no instructions within a reasonable time after notification of rejection the buyer may store the rejected goods for the seller's account or reship them to him or resell them for the seller's account with reimbursement as provided in the preceding section. Such action is not acceptance or conversion."

135. It is suggested that the time the rejecting buyer must retain the goods under $\S 2-602(2)(b)$ is the same "reasonable time" given for seller to send instructions under $\$ \S 2-603,2-604$. 
stances of each case, and judicial interpretation cannot be divined by an abstract analysis period.

Section 2-603 provides that a merchant buyer must "follow any reasonable instructions." On the other hand, section 2-604 permits the buyer to exercise specific options when no instructions are received "within a reasonable time." Although the code states that the buyer's duty with regard to the sale of perishable goods or those threatening to decline in value speedily arises "in the absence of . . . instructions," 136 it seems likely that the draftsmen intended this to be construed as implying the qualification "within a reasonable time." If buyer receives otherwise reasonable instructions after a reasonable time has transpired but before he has disposed of the goods, the question arises whether the seller's tardiness relieves the buyer of the duty to follow the instructions.

The "reasonable time" qualification can be construed as requiring buyer to await seller's instructions for a minimum period beyond which buyer must follow the instructions only if he has not previously acted with regard to the goods. It would seem incongruous, in the case of perishables, to require the buyer to sell the goods when tardy instructions request that they be stored. Since the perishable goods provision requires sale only "in the absence of reasonable instructions" even late instructions, if received prior to resale, should govern the buyers conduct. ${ }^{137}$

In the case of non-perishables, a solution is more difficult. Should buyer be permitted to follow his own desires pursuant to section 2-604 or must he obey a tardy seller's instructions? The code gives the non-merchant buyer his choice of methods in handling goods "if the seller gives no instructions within a reasonable time." 138 The purpose of requiring a merchant buyer to follow instructions is to mitigate the distant seller's awkward task of handling goods mistakenly sent to the buyer. On the other hand, the options provided in section 2-604 are designed to permit any buyer a reasonable freedom of disposition when seller has not been sufficiently diligent to make provision for the disposition of his rejected goods. Although it is arguable that a dilatory seller should have no right to require the buyer to follow instructions when the buyer's convenience dictates otherwise, unless the delay increases the buyer's burden of following instructions, there seems to be no basis for permitting the buyer to avoid the instructions except as a sanction against the seller's tardiness, which seems to have little to recommend it.

The code does not specify the alternatives to the buyer when the instructions are not substantively "reasonable" in whole or in part, except to indicate that the buyer need not follow unreasonable instructions. Section 2-604 permits buyer to exercise the options when "no instructions" are sent and section 2-603 requires resale of perishables "in the absence of

136. UCC $\S 2-603(1)$.

137. However, if the buyer has resold perishable goods prior to tardy instructions, he should not be held to have acted beyond his statutory authority.

138. UCC \& 2-604. 
such [reasonable] instructions." It would seem manifestly unfair to deny buyer the options of section 2-604 or permit him to refuse resale required by section 2-603 merely because seller sent instructions if they are not reasonable. ${ }^{139}$ Thus "unreasonable instructions" should be construed as including "no instructions" and an "absence of . . . instructions." However, if the instructions request conduct which is considered unreasonable only in part, and the unreasonable element can be so separated from the remainder that the performance of the latter is essentially what the seller requested, it seems proper to require the buyer to carry out the reasonable part of such instructions. For example, seller may request that the goods be returned to him, but further instruct that they be packaged in aluminum foil. If under the circumstances the packaging material as designated is unreasonable, there remains no great hardship in requiring buyer to return the goods albeit in some other package. Buyer's responses to the instructions should be judged by the test of "good faith" as defined in the code. ${ }^{140}$

\section{Merchant Buyer's Duties as to Perishable Goods}

In the absence of instructions from the seller, the code imposes upon a merchant buyer the duty to make "reasonable efforts" to sell the goods for the seller's account "if they are perishable or threaten to decline in value speedily." 141 This provision is a marked departure from the common-law approach of making resale a rare exception. ${ }^{142}$ The obligation applies, however, only when the seller has no agent or place of business at the market of rejection. ${ }^{143}$

The code does not describe what goods are perishable; presumably the normal meaning of the term is to govern. In some cases classification may be relatively simple: most fruits, meats and vegetables deteriorate comparatively rapidly. But other goods, such as grain, nuts or sugar while subject to ultimate deterioration, will remain unimpaired for a significantly longer period of time. Interpretation is further complicated by the fact that

139. If the seller refuses to remove the goods or sends unreasonable instructions the buyer may be burdened by holding the goods. The code did not look directly at this problem. By analogy at common law if the seller refuses the return or rescission, the buyer may resell but is under no duty to do so, Rubin v. Sturtevant, 80 Fed. 930 (2d Cir. 1897) ; the buyer may separate the contract and sell off the part which is nonconforming, Columbian Iron Works and Dry Dock Co. v. Douglas, $84 \mathrm{Md}$. 44, 34 Atl. 1118 (1896). Where the seller refused to remove bulky and space consuming rejected iron from the plaintiff's property, the buyer could sell it and not be held to have accepted, Youghiogheny Iron \& Coal Co. v. Smith, $66 \mathrm{~Pa} .340$ (1870). See also, Jones v. Bloomgarden, 143 Mich. 326, 106 N.W. 891 (1906); Hitchcock v. Griffin \& Skelly Co., 99 Mich. 447, 58 N.W. 373 (1894); Little Rock Grain Co. v. A. Brubaker \& Co., 89 Mo. App. 1 (1901); Bach v. Levy, 101 N.Y. 511 (1886).

140. "Good faith' in the case of a merchant includes observance of reasonable commercial standards." UCC \& 2-103(1) (b).

141. UCC \& 2-603(1).

142. 3 Wirliston, Sales $\$ 498$ (3d ed. 1948) ; Rubin v. Sturtevant, 80 Fed. 930 (2d Cir. 1897) (non-perishable goods); Jones v. Bloomgarden, 143 Mich 326, $106 \mathrm{~N}$.W. 891 (1906) (beans deteriorated on arrival one day late, sold by the buyer). The Uniform Sales Act did not speak to the problem of disposal of rejected goods, in the detail of the code. Nor did it codify the common law.

143. See note 125 supra for the text of $\S 2-603(1)$. 
the rate of deterioration of many goods depends largely upon the environment in which they are stored: tomato plants would be adversely affected by cold, salt by humidity and tobacco by dryness. Since the purpose of requiring the buyer to sell is to prevent unnecessary wastage of the goods, ${ }^{144}$ the buyer in most cases can readily classify the goods as perishable or not in the light of his facilities and this policy.

The code, however, refers in the disjunctive to goods which are ". . . perishable or threaten to decline in value speedily." ${ }^{145}$ The latter clause might be interpreted as a mere modification or explanation of the term perishable, thus limiting "decline" in value speedily to physical deterioration. On the other hand, "decline in value speedily" might reasonably refer to a totally different class of goods: those whose physical properties might be stable but whose market valuation threatens to decline for wholly independent reasons. Following this construction, goods such as flagstones would be included in the statutory classification if the market price were falling speedily. Some assistance is provided by recourse to the policy of this provision: resale was intended to preserve society's resources and to limit the seller's economic loss. Salvage of goods subject to physical deterioration is clearly within the scope of both objectives, but sale of nonperishable goods before or during a price collapse serves only the latter purpose since, by hypothesis, there is no physical loss. However, the concurrent satisfaction of both purposes appears unnecessary. Moreover, the narrower interpretation would seem to make the code provision largely repetitive; it is submitted, therefore, that the statutory classification was intended to encompass both physical and economic deterioration.

Non-physical causes for devaluation of property can include style changes and seasonal variations as well as a general market decline. Presumably a style change, occasioning a loss in value for an indefinite period of time, will require a buyer of goods subject to the change to resell them. A true seasonal decline, however, may effect only a temporary decline in value. Since the choice is between the buyer having to resell or to store the goods until the season returns, it seems more equitable to permit storage. Contrast, however, the situation with regard to two seasonal items: air conditioners and lawn mowers. The return of warm weather will substantially restore the mower's full value; the air conditioner, though, may be dated as a 1957 model so that the decline may not be fully restored in 1958. Although the seller's potential loss from seasonal decline may be comparable to that suffered in the case of general decline-the market for the 1957 model air conditioner may be as low in the summer of 1958 as it is in the summer of 1957-because the ensuing events are so speculative the buyer should not be penalized for guessing wrong. In any event, the buyer may have difficult problems of market analysis with respect to nonperishables: he will be forced to determine the existence, degree and

144. See note 114 supra.

145. UCC \& 2-603(1). 
rapidity of the threatened decline. Certainty was obviously not the dominant objective when this "declining speedily" provision was drafted.

Aside from the difficulties in the application of the foregoing clauses, the code offers no guide for determining the relevant market in which the decline is to be measured..$^{146}$ If the code is interpreted to require buyer to sell only in cases of general decline, a buyer who mistakenly believes that he must sell when the local market is falling may cause a seller unnecessary and non-compensable injury. Conversely, if a local market failure was intended to require buyer to sell and he fails to do so, relying upon a favorable general market, he would not necessarily be exempt from liability despite possible saving to the seller. Neither the language nor the policy of the code indicates the interpretation intended. Unless the code is clarified, fairness would seem to demand that it be construed as relieving the buyer of the duty to sell when either the local or the general market is stable. As a practical matter, however, the buyer will seldom be liable. His risks are considerably lessened by the code's express proviso that "in complying with this section the buyer is held only to good faith. . . ." 147 For merchants, "good faith" purports to include more than "mere honesty": " 'Good faith' in the case of a merchant means honesty in fact and the observance of reasonable commercial standards of fair dealing in the trade." 148 Thus, if buyer's act in refusing to sell in a threatening market has no reasonable or commercial justification, he will be liable for his failure to use good faith. Theoretically the impact of this provision can vary according to the relevant practices of the trade: commercial standards of fair dealing in one trade might well approach a test similar to reasonable commercial judgment, while the standards in another might be no higher than mere honesty. More likely, however, the courts will adopt reasonable business practices and standards as the yardstick in many cases. Since the code of ethics of the trade or the honesty of the particular buyer are difficult to ascertain, the buyer's divergence from commercial reasonableness may be indicative of a lack of good faith.

The standard of buyer's conduct may be further elevated by another underlying factor. When tested by hindsight, buyer's evaluation of the situation may seem less sound than appearances at the critical time would have indicated. Although a court would theoretically test buyer's conduct on the basis of the market as it appeared to him at the time, after-the-fact knowledge is difficult to disregard. The court may therefore find it hard to apply the good faith standard so as to enable the buyer to understand the

146. It is suggested that since $\S 2-603$ (1) places a duty on the buyer only when the seller has no agents in the market place of rejection, then this area might be taken as the scope of buyer's concern as to price also. The knowledge of most merchant buyer's as to price is at least certain in their own market place. Few items have a national market price such as stocks and bonds. Flagstones might have forty different prices in forty market places.

147. UCC \& 2-603(3).

148. UCC $\$ 2-103(1)(b)$. 
type conduct demanded of him, but its experience in handling similar common-law concepts should ease the burden. ${ }^{148}$

\section{Exceptions and Special Cases}

\section{Seller's Agent or Place of Business at the Market of Rejection}

The duty to follow instructions or to resell perishable or economically unstable goods is imposed on the buyer only in the cases where seller ". . . has no agent or place of business at the market of rejection." 150 Imposition of such duties upon the buyer is justified as protecting a distant seller, one whose place of business is not local, who otherwise would be helpless to salvage his goods. The terms "agent" and "market of rejection" should be interpreted in light of this policy. The comment to section 2-603 indicates that a financing agency handling the documents relating to the goods in issue would be an agent within the meaning of section 2-603.151 The draftsmen presumably reasoned that the buyer should be relieved of such duties whenever the seller is represented by some responsible individual.

While the code's premise is to burden the buyer only when necessary, it would in some cases be more equitable to charge the buyer with the applicable duties notwithstanding that seller has some contacts in the buyer's geographic region. ${ }^{152}$ Because of buyer's knowledge of the relevant trade practices, buyer would be in a better position to accept responsibility than one who is an agent of the seller for some purpose unrelated to the type of transaction involved. While a regional sales office or warehouse would clearly be an agent, a drummer staying only a few days in buyer's city would be a more questionable case. Similarly, a law firm retained locally by seller would be only remotely connected with the problem of the rightful rejection of the goods in question, and preferably should not be considered seller's agent within the meaning of section 2-603. By this view the comment's suggestion that buyer be excused when a financing institution is handling the documents seems equally unreasonable. The code's alternative reference to seller's "place of business" 153 suggests the substantiality of seller's local representation that should be required before excusing the buyer.

Application of the indefinite concept of "market of rejection" also presents a problem. The use of the term "market" here is unfortunate,

149. If the buyer under $\S 2-603(1)$ is required to resell perishables in the absence of instructions and on the day of this resale the market is oversupplied, a buyer would seem to be using a merchant's good faith if he placed the goods in storage for the purpose of selling them in a more advantageous market a week later. Even if the price further declines the courts should not by hindsight penalize the buyer.

150. UCC $\S 2-603(1)$.

151. See UCC $\S 2-603$, comment 2. See also UCC $\S \S 3-703,5-112$ (concerning the bank's duties with respect to rejected documents).

152. If the agent is a purchasing agent of raw materials, or a stock transfer agent, or an agent connected with a subsidiary of the seller's not necessarily in the same line of business, a buyer would be in a closer commercial situation to enhance salvage.

153. UCC \& 2-603(1). 
since it may have misleading connotations. It seems that "market of rejection" was intended only as a reasonable geographic limitation, and means the area or region where rejection occurred. In attempting to describe the relevant geographic area, it no doubt is desirable to avoid terms susceptible to technical evasion, such as "buyer's city." A flexibility was intended which would permit adjustment in each case as the code's policy dictates. ${ }^{154}$

\section{Buyer's Disposition of Rightfully Rejected Goods}

Section 2-604 provides that "if seller gives no instructions within a reasonable time after notification of rejection buyer may" store, reship, or resell the goods. These options are available to both merchant and nonmerchant buyers alike. Although the latter are not required to follow instructions received from the seller, they are under a duty to hold the goods "for a time sufficient to permit the seller to remove them. . . ." 155 Presumably they too need await seller's removal for a reasonable time after which they may exercise the options provided in section 2-604.156 The draftsmen's comments indicate that these options are not to be exclusive. ${ }^{157}$ Nevertheless, the stated alternatives appear to encompass all types of disposition consistent with minimizing loss to the seller; possibly the comment was inserted to safeguard against narrow construction by the courts.

While the exercise of section 2-604 options is expressly made not an acceptance or conversion of the goods, other code provisions permit the imposition of sanctions against buyers who dispose of rejected goods in a manner not authorized by sections 2-603 and 2-604.158 Any exercise of ownership by the buyer or an act inconsistent with the seller's ownership is either an acceptance or conversion of the goods. ${ }^{159}$ The vagueness of these criteria makes the legality of alternatives to these express options largely conjectural and their exercise risky. It seems likely that use or destruction of the goods by the buyer will preclude the buyer from shielding himself with section 2-603(3) or section 2-604. ${ }^{160}$ Although the seller had

154. Even if seller has a place of business at the market of rejection, but the buyer is unaware of this and seller does not inform the buyer of this, action by the buyer should be judged under the good faith test of UCC $\$ 2-603(3)$.

155. UCC § 2-602(2) (b).

156. See note 135 supra.

157. UCC § 2-604, comment.

158. If the buyer refuses to salvage under $\S 2-603$ or $\S 2-604$, and in fact wrongfully rejected the goods, the seller has two possible measures of damages. He may consider the rejection as wrongful and proceed under $\$ 2-708$ and $\$ 2-709$, or consider the rejection as rightful and proceed under $\$ 1-106(2)$. The latter course would be chosen when the goods as the buyer describes them on rejection have risen in price sufficiently to provide more return to the seller than the contract price of the goods as the seller describes them.

159. UCC $\$ 2-602(2)$ (a); see also note 120 supra.

160. UCC \& 2-604. This section does not specifically place a good faith test on the buyer. It states merely ".. . such action [referring to the options] is not acceptance or conversion." However, the comment to that section states that the good faith test is to apply. 
ample opportunity to remove the goods or to send instructions and has not done so, thereby burdening the buyer with unwanted goods, the code policy of salvage and mitigation of loss to the seller is preserved by denying the buyer the privilege of destroying the goods.

Closer scrutiny is required for an appraisal of the express options of section 2-604 and their permissible construction. Storage of the goods is the least questionable of the alternatives. It is the buyer's safest choice, since he is in no jeopardy of acting too soon unless he is a merchant buyer under a duty to sell. ${ }^{161}$ Furthermore, it is the course which the seller would probably prefer. The buyer may elect to store the goods in a warehouse or on his own premises. While the former might afford the seller more protection and the latter less expense, both methods are acceptable business practices and probably are included in the statutory option to store the rejected goods. However, since the options are exercisable only after the buyer has already waited a reasonable time for the seller to act (the goods being stored for that time), ${ }^{102}$ the buyer may prefer to discharge his responsibility for the goods by returning them to the seller or reselling them for the seller's account.

No special problems are presented by returning the goods to the seller. Permitting buyer to resell the goods, however, involves a potentially greater risk to seller than storing or shipping options. ${ }^{163}$ If buyer is able to sell the goods for a price equal to the seller's original sales price, seller has no complaint. Even if the general price level rose, since the seller would not receive less than his original expectation, the buyer's duty to act in good faith is sufficient protection. Several considerations justify the authorization of resale even when the amount realized thereon is less than the original contract price. Aside from the view that little indulgence need be shown a seller who shipped nonconforming goods and failed to respond to the buyer's notification of rejection, an alternative should be afforded the buyer who may be burdened by continuing to hold the goods and yet unwilling to return them if he has an unsatisfied claim against the seller for expenses or damages.

Previous discussion has related to resale when buyer has paid no part of the price; when buyer has paid all or part of the price, specific code provisions create different results. ${ }^{164}$ Section 2-711(3) provides:

161. The buyer must store the goods in a commercial warehouse for the seller's account, thus giving the seller control over the goods. Storage for buyer's account might be considered a conversion. See note 120 supra. Storage is an interim move awaiting return or resale but not by the seller.

162. UCC \& 2-602(2) (b).

163. A buyer acting under $\S 2-604$, desiring to preserve his business reputation and relationship with the particular seller, will take the economically feasible course. The buyer will consider present resale value, cost of return transportation, storage fees in relation to expected return, etc., and take the course which will produce the maximum return to the seller.

164. At common law and under the UNIForm SALES ACr $\$ 69(5)$ the security interest under the code was known as a lien. 
"On rightful rejection . . . a buyer who has paid all or part of the price has a security interest in goods in his possession or control for the amount paid plus any expenses reasonably incurred in their inspection, receipt, transportation, care and custody and may on notifying the seller of his intention to do so hold such goods and resell them in like manner as an aggrieved seller (Section 2-706)."

A buyer coming within the terms of this provision is specifically exempted from several of the requirements otherwise prevailing. Though the prepaying buyer must give notice of rejection he need not hold the goods a reasonable time for the seller's disposition. ${ }^{165}$ Moreover, a merchant buyer in this position need not follow seller's instructions. ${ }^{168}$ Although section 2-711(3) apparently exempts a merchant buyer also from the duty to sell perishable or economically unstable goods, since his authority to sell is expressed merely in permissive terms in 2-711(3), such exemption seems unintended and probably should be ignored. It would be anomalous to sanction the buyer's refusal to sell perishable goods just because he has a money claim against the proceeds, a fact unrelated to the salvage policy of section 2-603. The argument proceeding from the code would be that absolute dominion over the goods was not vested in the buyer for all purposes. The buyer's freedom to sell is only for the purpose of mitigating loss; if he does not exercise his privilege to sell and protect his own interests in the case of perishables, he nevertheless is under a duty to resell for seller's protection. Where non-perishable goods are involved it seems reasonable to permit buyer to ignore seller's instructions to the contrary and resell the goods. Buyer has an important stake in the sale and since seller is at fault, deference should be given buyer's interest. It is suggested, furthermore, that a buyer with a security interest under section 2-711(3) should be required to exercise his power of resale within a reasonable time. If buyer just sits by doing nothing, the seller is at a disadvantage, by hypothesis, having some value left in the goods. Buyer should be forced to act within this "reasonable time" or lose his security interest privilege, thereby becoming subject to sections $2-603$ or $2-604 .{ }^{167}$

Sales authorized by this subsection are governed by the procedure set forth in section 2-706. In accordance therewith the goods may be sold as a unit or in parcels, at public or private sale, and on any terms, provided the method, manner, time, place and terms are commercially reasonable. Certain safeguards are provided to insure a reasonable price at public sale. Furthermore, the party placing the goods for public sale is permitted to buy them at such public sale. ${ }^{168}$

165. UCC $\$ 2-602(2)(b)$.

166. UCC $\$ 2-603(1)$.

167. The "reasonable time" for buyer to act under $\S 2-711(3)$ could be the time that other non-security interest holding buyers would have to hold the goods for seller's disposition under $\S 2-602(2)(\mathrm{b})$.

168. At common law the buyer was not permitted to sell to himself. Glidden v. Mechanics Nat'l Bank, 53 Ohio St. 588, 599, 42 N.E. 995, 997 (1895). The court said 
Since procedures are not specified for resales authorized or instructed by sections $2-603$ or $2-604$, it was probably intended that buyer have considerable latitude. Nevertheless, it seems reasonable to require the application there also of the procedures set forth in section 2-706. A seller who has not received a prepayment should be entitled to the same protection on resale as afforded a seller against whom the buyer has a money claim from the proceeds of the sale. The draftsmen's "cross references" under sections 2-603 and 2-604 containing unexplained notations to section 2-706 provide some basis for invoking the latter provision. One problem arises upon application of section 2-706: Does the permission to buy for one's own account granted a party who resells under section 2-706 apply also to one who resells under either section $2-603$ or section 2-604? If the goods are offered at public sale, the seller's interest would not be jeopardized by permitting the party placing the goods on sale to purchase them; in fact, this could raise the eventual sale price, benefiting seller. If buyer is privileged to sell to a third party, there seems no reason to deny buyer himself the right of purchase if he pays the fair market value and acts in good faith. Nevertheless, as a prophylactic measure to assure buyer's good faith and to permit a more accurate evaluation of the local market price, buyer should be permitted to purchase the goods at a public sale alone.

\section{The Requirement That Goods be in Buyer's Possession or Control}

The buyer's duty to hold the goods with reasonable care is applicable only when buyer has taken physical possession of the goods before rejection. ${ }^{169}$ Apparently, the buyer will not be responsible for the carrier's failure to use reasonable care when the goods, after buyer's rejection, are in the carrier's possession, although buyer has the necessary documents to effect possession himself. This limitation evidences the code's policy of placing minimum responsibility upon the buyer. ${ }^{170}$ There seems no practicable basis, however, for distinguishing between a buyer's duty to use reasonable care according to when he acquired possession of the goods. Requiring one to use reasonable care when dealing with another's property, especially when the property was received in the ordinary course of business, is not so onerous that one should be excused when he gains possession of the goods after rejection.

in dicta that it is conversion. only if the pledgee refuses to return the goods to the pledgor. See Cullen v. Bimm, 37 Ohio St. 236 (1881). See also Bryan v. Baldwin, 52 N.Y. 232 (1873). The pledgor may refuse to recognize such a sale. Glidden v. Mechanics Nat'l Bank, stupra at 601,42 N.E. at 998 . A later case modified this rule though holding that the price set at the sale is not conclusively the market price of the goods in question. D. Rosenbaum's Sons v. Davis \& Andrews Co., 111 Miss. 278, 71 So. 388 (1916) (dicta). Cf. White v. Miller, $43 \mathrm{~Pa}$. Super. 572 (1910). After the seller refuses to rescind the buyer may use the goods himself and is liable only for the actual market value of those goods. However, a latter case under the Uniform Sales Act permitted the buyer to sell to himself if the protection of sufficient bids and good faith were shown. Wilson \& Co. v. M. Werk Co., 104 Ohio St. 507, 136 N.E. 202 (1922).

169. UCC \& $2-602(2)(\mathrm{b})$.

170. See UCC $\S 2-602$, comment 2 . 
The duty to follow instructions or to salvage is applicable to a merchant buyer where he has "possession or control of the goods." 171 These duties, though extended to buyers who can control the goods even without physical possession, are not beyond what one may be reasonably expected to do.

\section{Unsolicited and Accommodating Shipments}

As previously discussed, seller may ship goods to buyer other than as acceptance or performance of a contract. ${ }^{172}$ Normally this would be an accommodation shipment, a counter-offer, although at times it may constitute an unsolicited offer. Buyer may refuse to accept such goods. However, the code does not clearly indicate whether buyer's handling of these goods is to be governed by the rules applicable when seller's delivery is a breach of contract.

Section 2-601 provides that the buyer may reject when goods ". . . fail in any respect to conform to the contract. . . ."; three following sections provide for the manner of rejection and the buyer's rights and duties after rightful rejection. In the case of an unsolicited or accommodating shipment, there is no contract: therefore rejection is not authorized by that section (2-601). Although the statutory scheme suggests that the sections following 2-601 are dependent upon that section, there is no statutory authority limiting the applicability of the succeeding provisions to the scope of a 2-601 rejection. ${ }^{173}$ Any rightful refusal to accept goods should be a rejection within the meaning of those sections.

The policy of the code, moreover, suggests that the buyer's disposition of accommodating goods be governed by the same rules applicable to other rightfully rejected goods. There should be no lesser duty on the buyer since he is no more innocent; the seller should be subject to no greater risk of loss since he sent accommodating goods and not nonconforming goods. In the case of accommodating goods, the seller's action is an aid to the buyer who at least indicated willingness to do business with the seller.

There seems less basis for imposing obligation upon the recipient of unsolicited goods. Nevertheless, safeguarding the goods from destruction

171. UCC \$ 2-603(1).

172. UCC $\$ 2-602(2)$ states: "Unless the seller states the contrary a shipment sent in response to an order to which it does not conform is an acceptance and at the same time a breach. But a shipment of non-conforming goods offered as an accomodation to the buyer in substitution for the goods described in the order is not an acceptance." Note that silence on the seller's part will operate to make the goods an acceptance of the buyer's offer. It seems unlikely that a seller sending nonconforming perishable goods would label them as accomodating goods and lose the salvage aid, unless damages from breach would be large. If the latter is so the seller would not accept the buyer's offer in the first place.

173. It may be argued that under $\$ 2-601$ goods sent not subject to any contract "fail to conform to the contract," and thus \$2-601 applies. The policy for salvaging accomodation goods is that these goods are usually the wrong kind but not defective in their own physical properties. For example, the buyer might order Temple Oranges and the seller might accomodate with King Oranges in perfect condition. It would be a serious waste for these goods to deteriorate because of too tight a reading of $\S 2-601$. 
and the seller from capricious injury justifies placing some duties on the holder. It appears unreasonable, however, to require the recipient to follow instructions or to sell perishable goods; holding the goods with reasonable care should be sufficient. Although so limiting the duties of section 2-603 is not expressly authorized, there is no indication that rejection of unsolicited goods was contemplated by the draftsmen.

\section{Expenses and Commissions}

The duties imposed upon buyers are substantially ameliorated by liberal provisions for reimbursement. ${ }^{174}$ The merchant buyer who is required to sell perishables or goods which threaten to decline in value speedily or, regardless of the goods involved, is instructed to resell, is entitled to reimbursement for reasonable expenses incurred, including ". . . such commission as is usual in the trade or if there is none [then] to a reasonable sum not exceeding ten per cent on the gross proceeds." 175 Furthermore, any buyer electing to resell goods pursuant to section 2-604 is permitted reimbursement to the same extent. ${ }^{176}$ The prospect of earning a commission will further encourage exercise of the resale option at the best obtainable price. This possibility is not undesirable, for resale is available under section 2-604 when the seller is dilatory in responding to notice of rejection and, as a general rule is no more injurious to seller than the other options.

Buyers who follow instructions under section 2-603 or elect the section 2-604 option to store or reship may also be reimbursed for expenses. Under section 2-603, the merchant buyer's duty "to follow any reasonable instructions" is negated if on buyer's demand indemnity for expenses is not forthcoming from the seller. ${ }^{177}$ Although the code does not specifically so provide for reimbursement of expenses to the buyer, if the buyer has failed to seek indemnity for expenses before acting, it is unlikely that the courts will interpret the omission of such provision as negating the right to payment which was recognized at common law. ${ }^{178}$

\section{Withholding Proceeds as a Set-Off Against Damages}

The comment to section 2-711(3) suggests a further problem: May buyer use the proceeds of sale to satisfy any damages resulting from breach of contract? ${ }^{170}$ Assume buyer orders dress shoes, prepaying $\$ 100$ of the $\$ 500$ purchase price, and seller improperly delivers work shoes. Buyer

174. UCC $\S \S 2-603,2-604$. The latter section states: “. . .with reimbursement as provided in the preceding section."

175. UCC § 2-603(2).

176. See note 174 supra.

177. Under $\$ 2-603(1)$ if the buyer requests but the seller does not indemnify for expenses, the seller's instructions are not considered reasonable.

178. See note 132 supra.

179. See UCC § 2-711(3), comment 2. 
resells the work shoes for $\$ 400$, incurs incidental expenses of $\$ 50$, and is forced to buy dress shoes of the same quality elsewhere for $\$ 700$. Clearly buyer may keep $\$ 150$ (prepayment plus expenses), but the code indicates that he may not retain the $\$ 200$ difference between the contract price and the market price, his measure of damages, to which he would be entitled in an action against the seller. The buyer obtains a security interest for the price paid plus certain incidental expenses, and upon resale of the goods he "must account for any excess over the amount of his security interest. . . ."180 This restriction protects seller from the risk that buyer might overstate his damages. However, since seller would be entitled to recover any amount in excess of the proper measure of damages, the principal impact of this provision in determining whether buyer may withhold funds or remit them to seller is that seller would be placed in a more favorable position with regard to settlement. It is submitted that, since seller has breached the contract of sale, buyer should be permitted to retain damages, placing the burden upon seller to sue or otherwise adjust any damages. So amending the code would align this section with the provision which permits buyer to deduct damages from any part of the price remaining to be paid. ${ }^{181}$

Whereas the original version of section 2-711(3), now law in Pennsylvania, ${ }^{182}$ and the Uniform Sales Act ${ }^{183}$ are applicable only to the buyer who has paid all or part of the price, case law and the proposed revision of code section 2-711(3) ${ }^{184}$ extend a security interest to buyers who incur expenses only, regardless of whether they have paid any of the price. ${ }^{185}$ There seems no reason for granting the buyer who has disbursed funds in payment of the purchase price a better position than the buyer who has incurred other expenses, such as prepayment of freight. Consequently, the proposed revision properly abandons the distinction. ${ }^{186}$

180. UCC $\S 2-706(6)$.

181. UCC \& 2-717.

182. Pa. Stat. AnN. tit. 12a, § 2-711(3) (Purdon 1955).

183. UNIForMr SAlES ACT $\S 69(5)$. A lien was given for only the price paid regardless of expenses.

184. 1957 DRAFT changes 2-711(3) to read "On rightful rejection or justifiable revocation of acceptance a buyer [who has paid all or part of the price] has a security interest in the goods in his possession or control for [the amount paid plus] any payments made on their price and any expenses reasonably incurred in their inspection, receipt, transportation, care and custody and may [on notifying the seller of his intention to do sol hold such goods and resell them in like manner as an aggrieved seller. (Section 2-706)." The bracketed parts are to be omitted and the italicized part is to be added.

185. See note 132 supra.

186. An interesting question remains: Is the security interest described in $\$$ 2-711(3) the same as a security interest under UCC article 9? See UCC $\$ \S 9-203$ (1) (a), 9-302(1) (a) and 9-305(1). If the rightfully rejecting buyer is a "buyer in the ordinary course of business" under $\$ 9-307(1)$, he is protected in his security interest from a prior secured creditor of the seller. If he is not, however, the prepaying buyer should at least have a security interest under article 9 so as to be protected from subsequent secured creditors of the seller. This would enable buyers to gain a priority under $\S 9-312$. 


\section{CONCLUSION}

In designating buyer's duties with regard to goods rightfully rejected, the code's draftsmen gave prime emphasis to the preservation of society's resources and the inconvenience which assumption of these duties would create for the buyer who was not at fault. Accordingly, such obligations vary under the code depending upon the type of goods involved, the buyer's merchant status, location of the seller and location of the goods. These provisions are largely beyond reproach. Although some may challenge the underlying considerations as sacrificing the buyer in order to benefit the seller, the result seems one which conforms the requirements of the law to the ethics of the business community.

\section{PART III. PERFORMANCE-THE DOCTRINE OF IMPOSSIBILITY}

Once a contract has been formed, each of the contracting parties reasonably expects that the other will perform. ${ }^{187}$ Unless the performance involved is in derogation of an established public policy, the law will, in most instances, insist that each party fulfill his promised act; failing this, the injured party is afforded a remedy. At times, however, events render compliance with the agreed terms impossible. If the parties had the foresight to anticipate this eventuality and included in their agreement an alternative course of conduct, their predicament is readily solved.188 Doctrinally, one might suggest that in such cases performance under the contract is not impossible; the parties are merely complying with the alternative course specified conditionally in the contract and rendered operative by the occurrence of the named event.

Normally, when an event prevents performance as agreed, its occurrence was not contemplated by the parties. If the event was the fault of either party, the conduct of the party responsible is actionable at the election of the other. When, however, neither is at fault, which of them is to bear the loss is a more difficult problem. If the risk is to be borne by the seller, he must place the buyer in the position in which buyer would have been had the contingency not occurred. If the buyer has the risk, he will have

187. See, e.g., Patterson, Constructive Conditions in Contracts, 42 CoLum. L. REv. 903, 943 (1942).

188. As a matter of course, the conscientious draftsman of a sales contract will include detailed clauses purporting to allocate various risks such as fire, flocd, strikes and war. See 6 WILIISTON, CoNTRACTS $\S 1972 A$ (rev. ed. 1938); e.g., the terms in the following contracts: Consolidated Coal $\mathrm{Co}$. v. Peninsular Portland Cement $\mathrm{Co} .272$ Fed. 625, 627 (6th Cir. 1921) (contingencies of transportation); Haigh Hall S.S. Co. v. Andersen, 246 Mass. 34,140 N.E. 302 (1923) (hindrances beyond [seller's] control); see also Jessup \& Moore Paper Co. v. Piper, 133 Fed. 108 (C.C. E.D. Pa. 1902); Hatfield v. Thomas Iron Co., $208 \mathrm{~Pa} .478,57$ Atl. 950 (1904) (subject to strikes). 
lost the advantage for which he bargained and, in addition, may suffer perhaps greater injury by his subsequent inability to perform other commitments as readily as he might have if the event had not transpired. ${ }^{189}$

Considerations affecting the apportionment of risk in this situation are equally pertinent where performance, while not impossible, is deemed commercially impracticable. Determination of the circumstances in which seller's performance is considered commercially impracticable or impossible is not simple. The common law developed a doctrine of "impossibility" to cope with such contingencies. It was probably a feeling that the problems involved required the flexibility characteristic of the common-law development that accounted for the absence of "impossibility" provisions in uniform commercial legislation prior to the code. At any rate, the code has attempted to afford a statutory framework both broad enough to provide the flexibility necessary for judicial settlement of disputes after the event and of sufficient definiteness to enable businessmen to so order their affairs as to avoid disputes in advance. ${ }^{190}$

Although the language of the code provisions focuses upon events which preclude the seller's performance, the draftsmen's comment indicates that the rules are also applicable when events frustrate the buyer's expectations. The ensuing analysis will be in terms of the seller's performance; its application to buyer's frustration, to the extent that this doctrine has vitality, should become fairly self-evident.

\section{Adjusting a Disrupted Deal: Excusing the Seller Because of SuPERVENING FACTS}

While the civil law excused the promisor when a supervening contingency made performance of a contract impossible, ${ }^{191}$ the early common law proceeded from the opposite premise. ${ }^{192}$ That doctrine remained

189. Both parties to a contract may make numerous and expensive arrangements in reliance upon the performance of a contract: The seller might hire extra workmen to prepare the goods, rearrange his work force, expand his plant, increase his product advertising, make new contracts or negotiate modifications in old ones with the carriers with which he normally deals; the buyer might rely upon performance in making other deals to resell the goods or in refusing to buy competing goods, or he might expand his warehouse space or plan a large sale.

190. See Gilmore, On the Difficulties of Codifying Commercial Law, 57 YALE L.J. 1341 (1948). "First, it is a matter of vital importance that the Code as a whole be kept in terms of such generality as to allow an easy and unstrained application of its provisions to the new matters of business behavior. Commercial codification cannot successfully overparticularize; the penalty for being too precise is that the statute will have to keep coming in for repairs (and amendment is a costly, cumbersome and unsatisfactory process) or else become a dead letter." Id. at 1355.

191. See McElroy, Impossmility of Performance 3 (1941); Page, The Development of the Doctrine of Impossibility of Performance, 18 MICH. L. REv. 589, 591-92 (1920).

192. The common-law rule seems to have been established in the case of Paradine v. Jane, Aleyn 26, 82 Eng. Rep. 897 (K.B. 1647). This rule was that a contractor will not be excused from his promise regardless of the supervening events because he might have provided against such contingencies in his contract. See McElrox, op. cit. supra note 191 at $4-5$. 
relatively intact ${ }^{193}$ until the decision in Taylor $v$. Caldwell. ${ }^{194}$ In that case plaintiff agreed to rent a music hall from defendant, but prior to plaintiff's occupancy the music hall was destroyed by fire. Upon suit for damages arising from nonperformance, the court held that continued existence of the music hall was an implied condition of the contract; the non-occurrence of this condition excused the defendant. ${ }^{195}$ Since that case, the common law has recognized that impossibility of performance may, in a proper case, constitute a defense for nonperformance. ${ }^{196}$ Resort to the fiction that the contract premised an "implied condition" that performance remain possible was probably undertaken to avoid the objection that excusing the promisor violates the "sanctity of the contract." 197 More practically, if there were a contrary assumption the contract, viewed by hindsight, would have had little commercial value.

The fictional approach has been severely criticized on the ground that the courts' sense of "justice" should not be obfuscated by assumptions about the parties' intentions; such equitable determinations should, it is urged, be expressed in a forthright manner. ${ }^{198}$ Varying approaches have been suggested for determining when events should properly excuse the seller from performance. One view looks to what the parties would have done had they contemplated the occurrence of the contingency. ${ }^{199}$ This formulation, however, while recognizing the likelihood that the parties neither contemplated the event nor implied a condition excusing the seller, is of limited practical utility since it turns on the intention of the parties who, at the time of the trial, are no longer unanimous.

A more useful approach is to regard the problem as one of apportionment of risk. If the issue were posed in terms of which party assumed the risk or would have if the contingency had been contemplated, the difficulties

193. The only modifications imposed upon this doctrine were that a contract might be discharged by (1) death of the party where the undertaking was personal, (2) destruction of a specific chattel which was the subject matter of a contract of bailment, (3) illegality owing to the operation of a subsequent act of Parliament. McELROY, op. cit. supra note 191, at 5; Note, The Fetish of Impossibility in the Law of Contracts, 53 Colum. L. REV. 94, 95 (1953).

194. 3 Best \& Smith 826, 122 Eng. Rep. 310 (Q. B. 1863).

195. See also Texas Co. v. Hogarth Shipping Co., 256 U.S. 619 (1921) ; Israel v. Luckenbach S.S. Co., 6 F.2d 996 (2d Cir. 1925) ; F.A. Tamplin S.S. Co. v. AngloMexican Petroleum Products Co., [1916] 2 A.C. 397.

196. See, e.g., 6 WILLISToN, op. cit. supra note 188, $\S \S 1931-79$.

197. See McElrox, op. cit. supra note 191, at 61-67. Courts have asserted eloquently that a certain state of facts, though not expressed was the "foundation" of the contract, see F.A. Tamplin S.S. Co. v. Anglo-Mexican Petroleum Products Co., [1916] 2 A.C. 397 (government requisition of ship did not terminate charter party, but merely postponed), or that performance of a contract depended upon a certain set of facts which were "tacit assumptions," see Texas Co. v. Hogarth Shipping Co., 256 U.S. 619 (1921) (ship owner discharged from obligation under charter party upon requisition of ship likely to extend and does extend beyond the time for projected charter voyage) ; Israel v. Luckenbach S.S. Co., 6 F.2d 996 (2d Cir. 1925); see also Fleetwood v. Brown, 109 Ind. 567, 9 N.E. 352 (1886).

198. See 6 Williston, op. cit. supra note 188 , § 1937; 6 Corbin, Contracts \$ 1331 (1951) ; Note, The Fetish of Impossibility in the Law of Contracts, 53 Colum. L. REV. 94, 102 (1953).

199. See Patterson, supra note 187 , at $946-48$. 
already mentioned would be present, but if considered on the basis of commercial desirability a more meaningful determination of risk apportionment may be made. ${ }^{200}$ The interests of the parties can be considered in terms of the type goods with which they deal, whether the seller is a producer, middleman or retailer and the buyer a middleman, retailer or consumer, their respective abilities to insure against the disabling event or to bear the loss or distribute it, and the implications of placing the loss on each. Also important is the nature of the disruptive event and the extent to which performance as agreed has actually become physically impossible or commercially impracticable. It is somewhat difficult to explain the willingness of the common law to establish, and the code's draftsmen to continue, the impossibility defense whether it be rationalized on the ground that the parties would have so agreed or because the buyer is considered a better risk bearer. The buyer is an innocent party, willing to perform, and his suit is grounded in contract, which normally links liability for loss to nonperformance rather than to hypothetical intentions or to some notion of a better risk bearer. Possibly the rationale for exempting the seller from damages and hence placing the loss on the buyer is the courts' unwillingness to change the position of the parties from that in which the unforeseen contingency left them.

Analytically, the impossibility doctrine can be stated as permitting the seller to refrain from performance. Although this conception may be accurate when it is physically possible for seller to deliver conforming goods, in most instances this analysis is misleading. The question normally arises when it is impossible for the seller to comply with the contract; the doctrine then should be regarded as excusing the promisor from responding in damages.

The code treats impossibility in several sections, each concerned with a separate situation. Section 2-613 pertains to a casualty loss of "identified goods which are irreplaceable or are treated by the parties as unique." 201 In such case, as under the Uniform Sales Act, ${ }^{202}$ if the loss is total the contract is avoided; if the loss is partial the buyer may elect to avoid the contract or accept such goods as were not destroyed. The section also applies where goods shipped under a "to arrive" term are late in arrival. A departure from the Sales Act grants the buyer a price allowance for the deterioration in quality or deficiency in quantity regardless of whether the contract is considered "divisible" or "indivisible."

Section 2-614(1) is concerned both with the unavailability of berthing, loading, or unloading facilities or of the type of carrier which had been

200. See Note, The Fetish of Impossibility in the Law of Contracts, 53 Corum. L. REv. 94, 98 (1953). As a correlative theory, the above note writer suggests that the courts, in determining whether or not to excuse a seller, should tend not to excuse those ventures which are under-capitalized or inadequately managed. Id. at 101-02.

201. UCC § 2-613. The 1957 Draft of this section of the code was amended so that the first clause now reads: "Where the contract requires for its performance goods identified when the contract is made. ..."

202. UNIFORM SALES ACT $\S \S 7-8$. 
agreed upon, and with the commercial impracticability of the agreed manner of delivery. Rather than wholly excusing the promisor from performing, when a commercially reasonable alternative is available resort to it must be made. ${ }^{203}$ Such alternate facilities are those which the circumstances, usage of trade or prior course of dealing have established as commercially acceptable. ${ }^{204}$ "Commercial impracticability" is the only concept in this subsection sufficiently vague or complex to warrant further discussion; this will be treated in considering the operation of section 2-615. Assuming that the facilities, type of carrier or manner of delivery were not so essential to the contract that had their non-availability been known at the time of the deal's formation the transaction would still have been consummated, requiring substitution would be consistent with the original intention of the parties. ${ }^{205}$ Since this assumption is likely to premise most contracts, the rule seems well founded. Furthermore, when the availability of the facility is essential to one of the parties, a term can be included in the contract negating the operation of this subsection. ${ }^{206}$

When the contract is wholly executory, if governmental regulation prevents payment in the agreed manner or means, section 2-614(2) permits the seller to withhold or stop delivery unless the buyer substitutes a substantially equivalent manner or means of payment. On the other hand, if the only remaining act is payment of the purchase price, the buyer may pay as provided by the regulation, even though not commercially equivalent

203. "Where without fault of either party the agreed berthing, loading, or unloading facilities fail or an agreed type of carrier becomes unavailable or the agreed manner of delivery otherwise becomes commercially impractical but a commercially reasonable substitute is available, such substitute performance must be tendered and accepted." UCC \& 2-614(1).

204. See UCC \$ 1-205.

205. The Supreme Court originally held that contracts must be performed to the letter. Filley v. Pope, 115 U.S. 213 (1885). But more recent cases have permitted tender of technically nonconforming delivery which does not affect the "heart" of the contract. See, e.g., Harrison v. Fortlage, 161 U.S. 57 (1896); see also Meyer v. Sullivan, 40 Cal. App. 723, 181 Pac. 847 (1919); Whitman v. Anglum, 92 Conn. 392, 103 At1. 114 (1918); Blackburn Bobbin Co. v. T.W. Allen \& Sons, [1918] 2 K.B. $467 ; 6$ Corbin, op. cit. supra note 198, 1339 n.64 (citing code). But cf. Mitsubishi Goshi Kaisha v. J. Aron Co., 16 F.2d 185 (2d Cir. 1926). One firm has suggested that a problem in code interpretation might arise as to whether the seller or the buyer must pay any additional expense, if any, of a "commercially reasonable substitute." The corporation proposes that "it would seem more reasonable to provide that, except as otherwise agreed, substitute performance must be rendered or accepted at the request of either party, provided the requesting party assumes any additional expense incurred as a result of such substitute performance." Under the code such a test does not seem to be authorized. This corporation was addressing itself primarily to the problem of forcing the buyer to accept substitute performance involving heavy additional expense. It would seem that a court would prevent such a hardship by use of the statutory term "reasonable." The suggestion seems sound, however, that the buyer should be permitted to force the seller to tender an "unreasonable" substitute performance provided the buyer assumes the additional expense.

206. See UCC \& 1-102(3) (c): "The general obligations prescribed by this Act such as good faith, due diligence, commercial reasonableness and reasonable care may not be disclaimed by agreement but the parties may by agreement determine the standards by which performance of such obligations is to be measured if such standards are not manifestly unreasonable." See also UCC \& 1-102(3)(d): "Provisions of this Act which are qualified by the words 'unless otherwise agreed' or words of similar import may be waived or modified by agreement and the absence of such words contains no negative implication." The latter section has been omitted from the 1957 draft. 
to the agreed manner, "unless the regulation is discriminatory, oppressive or predatory." 207 The latter provision seems an equitable solution to a difficult problem. As a practical matter, business courtesy and the desire for continued good relationships and reputation compel the buyer to use caution in making payment. However, if seller has already made delivery, the fact that a commercially equivalent means of payment is unavailable should not put buyer in breach; seller having proceeded with delivery after equal opportunity to discover the regulation, buyer's obligation should be discharged by payment in accordance with the regulation. But buyer's observance of a regulation which is "discriminatory, oppressive or predatory" should not excuse his failure to pay seller by the agreed means or manner or the commercial equivalent thereof. ${ }^{208}$

In all other instances, seller's delay in delivery or non-delivery is excused only if the conditions of section 2-615 are met. These conditions embody the draftsmen's theory as to when the seller should be excused. A close examination of this section is necessary to appreciate the draftsmen's test and its range of operation.

\section{Excuse: Failure of Presupposed Conditions}

Under section 2-615(a), a seller is excused from contractually agreed performance if three conditions are met: (1) a contingency must occur; (2) performance as agreed must thereby be made "impracticable"; and (3) the non-occurrence of the contingency must have been a "basic assumption" on which the contract was formed. ${ }^{209}$ Strictly speaking, each of the foregoing concepts can be found in the common law, ${ }^{210}$ but their presence in statutory form requires fresh analysis. Judicial treatment of

207. "If the agreed means or manner of payment fails because of domestic or foreign governmental regulation, the seller may withhold or stop delivery unless the buyer provides a means or manner of payment which is commercially a substantial equivalent. If delivery has already been taken, payment by the means or in the manner provided by the regulation discharges the buyer unless the regulation is discriminatory, oppressive or predatory." UCC \& 2-614(2).

208. See 6 Corbin, op. cit. supra note 198, § 1343: "We are all familiar with the many thousand of sealed bonds and other contracts for the payment of money that expressly required the payment to be in gold coin of standard weight and fineness. Performance according to this promise was then prohibited by act of Congress; and the validity of the prohibition was sustained by the Supreme Court." See also Louisville \& N.R. Co. v. Crowe, $156 \mathrm{Ky}, 27,160$ S.W. 759 (1913) (holding that a landowner who exchanged land with the railroad for a pass which subsequently became illegal was entitled to be paid in some other medium).

209. UCC §2-615: "Except so far as a seller may have assumed a greater obligation and subject to the preceding section on substituted performance: (a) Delay in delivery or non-delivery in whole or in part by a seller who complies with paragraphs (b) and (c) is not a breach of his duty under a contract for sale if performance as agreed has been made impracticable by the occurence of a contingency the non-occurrence of which was a basic assumption on which the contract was made or by the compliance in good faith with any applicable foreign or domestic governmental regulation or order whether or not it later proves to be invalid."

210. See, e.g., REsTateMENT, Contracts $\S 454$ (1932); 6 Williston, op. cit. supra note 188, $\$ \$ 1931,1952 ; 6$ CoRBIN, op. cit. supra note $198, \S 1331$. Professor Williston indicates the analogy between excuse due to failure of basic assumptions and mistake as to basic assumptions. 6 WILIISTON, op. cit. supra, \$1937. 
statutory terms may vary from the heretofore stare decisis approach, especially in view of the overriding commercial policy emphasized by the code.

Together the three conditions establish "a minimum [exemption] beyond which agreement may not go." 211 No explanation is offered for providing that only a greater obligation may be assumed. Presumably the draftsmen feared that otherwise a seller in a superior bargaining position could force a buyer to agree to seller's nonperformance when performance is not impracticable, and considered such an advantage socially or commercially undesirable. ${ }^{212}$ Although no loss to society is engendered by prohibiting the seller from avoiding performance when it is not impracticable, neither does there seem any significant harm in permitting such avoidance if the parties had agreed to it. In fact, abridging the businessman's right to contract on any terms consistent with well defined public policy seems a more significant evil than the discernible harm arising from the abuse of one's bargaining position. Unless a real mischief can be demonstrated, the parties should be permitted to contract on any basis agreeable to themselves. ${ }^{213}$

The code's recognition that a seller may contract to perform in all events seems proper. Since performance may at all times be physically impossible, the impact of such agreement is that the seller agrees to assume such risk regardless of the protection afforded him by the law. The common law similarly enforced such agreements. ${ }^{214}$

\section{Occurrence of a Contingency}

Among the prime functions of a contract is its utility in allocating and, in some instances, transferring risk between the parties to a commercial transaction. The value of this service is premised on the knowledge, derived from experience, that the posture of the commercial setting is not static. Whether recognition of this phenomenon in legal doctrine is couched in terms of "impossibility" or of "impracticability," the essence of the doctrine is excusing the seller where there has been a change in circumstances. The code's use of the word "contingency" indicates that excuse is predicated on a change of events traceable to an unusual occurrence. The draftsmen's comment to section 2-615 suggests that war, embargo, crop failure and the unforeseen shutdown of major suppliers are illustrative of contingencies warranting that section's application. ${ }^{215}$

\section{Impracticability}

To exempt seller from performance the change in circumstances, aside from being unusual, must have a marked effect on his ability to perform.

211. UCC \& 2-615, comment 8 .

212. Cf. UCC $\$ \$ 2-302,1-102(3)$ (c).

213. See UCC \$\$ 1-102(3) (c), (d), 2-303.

214. See, e.g., Whitman v. Anglum, 92 Conn. 392, 103 At1. 114 (1918). A seller may agree to do an impossible thing. See Patterson, sipra note 187, at $943 ; 6$ WrLlIsroN, op. cit. supra note 188, § 1934.

215. UCC \& $2-615$, comment 4. 
In this regard, designation of the common-law rule as a doctrine of "impossibility"is a misnomer, for although founded upon cases of physical impossibility of performance, the doctrine applied beyond such strict limits. Nevertheless, mere difficulty or unexpected expense of performance was not sufficient to excuse the seller. ${ }^{216}$ Phrasing the doctrine in terms of "impossibility," it has been suggested, emphasizes that promises are expected to be performed "even though it hurts." 217 How much it must "hurt" is not easily articulated.

The term "impracticability" was chosen by the code's draftsmen "to call attention to the commercial character of the criterion." 218 As a test, the statutory concept of "impracticability" is no less uncertain than the common-law standard, although it seems both more accurate in describing the common-law cases and more akin to the eventual objective of excusing the seller where, absent fault, performance is not forthcoming. No doubt the draftsmen contemplated an objective determination of whether the promise can reasonably be performed rather than a subjective inquiry into the promisor's capability of performing as agreed. ${ }^{219}$ Since the latter test would sanction excusing a seller with less than normal capabilities, it seems unlikely that the draftsmen-whose purpose it was to adopt a commercially acceptable standard-would permit more competent dealers to suffer because of their skills. ${ }^{220}$

Clearly, physical impossibility is encompassed under impracticability. Although few endeavors may literally be physically incapable of accomplishment today, the qualification that performance be within the time stated by the contract and by means normally comprehended by the parties increases instances of physical impossibility. Beyond this, changed circumstances may so alter the seller's position or so markedly increase his cost of performance that compliance with the contract would be considered impracticable. For example, destruction of seller's factory or crops as well as a labor strike would be regarded as rendering performance impracticable, even though it may be possible for the seller to obtain the goods from a

216. See, e.g., Restatement, Contracts $\$ 454$ (1932); 6 Williston, op. cit. supra note 188, \$ 1931. See also Jessup \& Moore Paper Co. v. Piper, 133 Fed. 108 (C.C.E.D.Pa. 1902) (here it was held that before a party could claim excuse because of impossibility, he must make "every effort reasonable in the trade" to find an alternative source); Vernon Lumber Corp. v. Harcen Constr. Co., 60 F. Supp. 555 (E.D.N.Y. 1945). The seller is not excused from delivering lumber which survived a fire ". . .by the mere fact that its location upon the tract is such that it would be very expensive for him to deliver it." International Paper Co. v. Rockefeller, 161 App. Div. $180,185,146$ N.Y. Supp. 371, 375 (3d Dep't 1914). But cf. Tennants (Lancashire)

Ltd. v. C.S. Wilson \& Co., [1917] A.C. 495.

217. See Patterson, supra note 187, at 943.

218. UCC \& 2-615, comment 3.

219. RESTATEMENT, CONTRACTS $\$ 455$ (1932) ; 6 WILLISTON, op. cit. supra note 187 , $\S 1932$; 6 CoRBIN, op. cit. supra note 198, \& 1332; Fast v. Shaner, 183 F.2d 504, 506 (3d Cir. 1950).

220. The code's draftsmen presumptively sought to avoid the converse situation where an inefficient seller could be excused simply by showing his own peculiar inefficiency. 
competitor or to settle the strike by agreeing with the strikers' demands so that he could perform within the specified time.

However, increased costs or other market fluctuations that adversely affect the seller so as to result in a monetary loss should performance be demanded seem unrelated to impracticability. Although "impracticable" is not defined in the code, its dictionary definition together with its commonlaw origin and the draftsmen's comments indicate that performance must impose a severe economic hardship on the promisor to warrant excusing him. ${ }^{221}$

\section{Basic Assumptions}

For impracticability to operate as an excuse, performance under the contract must be premised on the non-occurrence of the disruptive contingency or the continuance of the previous condition. Since the obligation to perform is founded in contract, it seems proper to channel excuse along the same theoretical approach. Nevertheless, as previously discussed,222 to determine either what the parties intended or what they would have intended had they considered the matter is a task not susceptible of measurably accurate determination. Although some assistance may be found in the circumstances surrounding the contract's formation, such a determination must in part be accomplished by perhaps unarticulated reference to what normal businessmen would do if faced with the issue, or possibly in terms of a theory-completely removed from contract notionswhich focuses on the parties' relative risk-bearing ability.

The comment to section 2-615 indicates that examination of the surrounding circumstances may reveal that the occurrence of the contingency was foreshadowed at the time of the contracting. ${ }^{223}$ Presumably the proper inference to be drawn is that the occurrence was part of the dickered terms, the seller assuming the risk in the event the contingency transpired. In addition, the comment suggests several conditions whose continuation may be regarded as "basic assumptions"; an example is production by an exclusive or agreed source of supply.224 The failure of a farmer-seller's crop is mentioned as an instance of an event the non-occurrence of which is a "basic assumption." 225

As is true in the case of events constituting a "contingency," it cannot be a "basic assumption" that all conditions will remain unchanged from their status at the time of contracting. Not only would this interpretation undermine application of the excuse provision, it has no basis in reality. The dynamic nature of the business community and its resort to contracts to

221. UCC § 2-615, comment 4.

222. See text at note 200 supra.

223. UCC $\$ 2-615$, comment 8 .

224. UCC \& 2-615, comment 5.

225. UCC \& 2-615, comment 9. 
allocate and transfer normal risks attests to a recognition that some conditions will change and that contracts must nevertheless be performed.226 Of those contingencies whose occurrence would render performance physically impossible, absent foreshadowing of such event or other evidence that seller assumed the risk the non-occurrence would be a basic assumption in virtually all instances. This becomes self-evident in view of the basic policy of excusing the seller when he is, without fault, unable to perform because of changed events.

The vexing problem in this area is the demarcation of those instances wherein performance is physically possible but a court would nevertheless conclude that the seller is excused. Such a conclusion presupposes an affirmative decision both as to the impracticability of performance and the existence of a basic assumption by the parties with regard to the nonoccurrence of the contingency. Although it is possible that only one of these conditions may be found, it would be unlikely. Positing physical possibility of performance, the determination of when performance would work such a hardship as to be deemed "impracticable" is essentially a question of which party may reasonably be regarded as the proper risk-bearer-a determination based upon the mores of the community and independent factors indicating the most equitable allocation of risk. ${ }^{227}$ A similar analysis is necessarily involved, absent available evidence, in determining whether there existed a basic assumption that the contingency would not occur. Normally the possibility of the disruptive contingency would not have entered the negotiations; ${ }^{228}$ when it does the problem is simply one of ascertaining whether any agreement was concluded pertaining to the allocation of risk. Hence, in the absence of such evidence, essentially the same factors are involved in determining "basic assumptions" as in finding "impracticability," and as a result the conclusions should logically be identical.

This is not to suggest, however, that the present formulation of the test for excuse is unwise or unnecessary. As indicated, in those instances in which some evidence of the parties' intention is available the code's statement is helpful. Furthermore, it is of value in high lighting the principles that must be regarded in the policy inquiry. The change in events must be in the nature of a contingency. Performance must be rendered impossible or at least most difficult. The parties must have premised their agreement-or reasonably be considered to have premised it-on a basic as-

226. See UCC \$ 2-615, comment 4.

227. See 6 Corbin, op. cit. supra note 198, § 1331 at 282.

228. See Patterson, supra note 187, at 946: "In the drafting of contracts between parties having fair equality of bargaining power, the words finally written in the instrument are often the result of a hard-fought compromise. To inject too many imaginable catastrophes into the negotiations is to cause irritation, doubt, even frustration of making. After the catastrophe has occurred, to say that the plaintiff who has sustained damage and is suing to recover for it, would have graciously consented to insert the condition which the court is now about to construct, is to conceal the evaluative judgment under a fictitious inference of fact." 
sumption as to the continuance of a given situation or the non-occurrence of the disrupting event.

\section{Selected Problems Involving Impracticability}

The interaction of the several conditions may best be perceived by examining specific situations involving non-performance which the seller contends should be excused. The broad and rather amorphous terms used in the code, while not affording complete certainty, do permit the courts a degree of flexibility. At the same time, assuming that the application of the code's standard will depart slightly, if at all, from the prior case law, the adjudicated cases will supply a fair amount of predictability. Furthermore, and perhaps more importantly, the prior decisions have so permeated existing notions of business propriety that one's instinct in many instances will indicate a proper result.

Seller's performance will normally be made impracticable by: (1) a contingency disrupting his own productive facilities, such as destruction of his plant or equipment or a strike by his employees; (2) the failure of his source of supply ; (3) the failure of facilities for transporting the goods; and (4) the application of a governmental regulation.

\section{Disruption of Productive Facilities}

One of the most recurrent hazards interrupting a seller's ability to perform his contractual obligations are strikes by his own employees or by employees of third parties with whom he deals. When the strikers are employees of seller's supplier or transportation company, the fact that it is a strike that has interfered with seller's performance is of no legal consequence in determining whether seller should be excused. Problems presented in that situation will be considered later. Where, however, it is seller's employees who are on strike, resolution of seller's claim of excuse is dependent upon analysis of the strike situation, in the absence of a contract provision governing the contingency.

Assume that one year ago seller contracted to supply his principal buyer with 5000 yards of fabric monthly at eight cents per yard; the contract was to run for two years. The current market price of the fabric is fifteen cents per yard. In the past year, costs of seller's raw materials, rent and machinery have risen. Furthermore, seller's employees are seeking a wage increase, contending that 80 per cent of the industry has agreed to an increase of ten cents an hour. These events prompt seller to ask buyer to modify their agreement increasing the price to twelve cents per yard, informing buyer that high costs and the wage demand would cause bankruptcy if seller is required to fulfill the contract at eight cents per yard. Buyer refuses seller's re-negotiation efforts. The union goes on strike, demanding a fifteen cent hourly wage boost and rejecting seller's counter-offer of four cents an hour. Continuation of the strike ultimately prevents performance under the contract and buyer sues seller for damages. 
Against seller's assertion of excuse, buyer could offer several arguments. Initially he could contend that seller's performance was not rendered impracticable; an increased wage offer could have averted or terminated the strike, so that it was merely increased cost that prevented performance. ${ }^{229}$ Since strikes or the threat of the same have become fairly commonplace, buyer would try to demonstrate that the possibility was foreshadowed at the time of contracting. ${ }^{230}$ The inference that the buyer wishes to be drawn is that the contract's silence indicates that seller bore the risk of any change in labor conditions. Finally buyer could urge that the strike and the non-performance were not causally related; seller simply thought that increased cost would make the contract unprofitable and refused to settle the dispute in order to avoid his contract obligation.

If seller is to be excused only when performance has literally become "impossible," it is clear that here seller cannot validly claim excuse. But pre-code case law recognized that cases of strict impossibility of performance were rare and that in many instances a performance which was "possible" might involve an unreasonable hardship. ${ }^{231}$ In view of its emphasis on commercial realities, the code probably should be interpreted as presupposing this fundamental concept. Nevertheless, the common-law courts tended generally to be strict in finding performance impracticable. ${ }^{232}$ In the hypothetical, if the strike question is set aside and seller is considered as being faced only with an increase in costs, even under the code it seems that a claim of excuse would not prevail. The comment to the code adopted the well recognized view that market fluctuations will not excuse performance since such vicissitudes are "exactly the type of business risk which business contracts made at fixed prices are intended to cover." 233

However, when the strike question is considered, a different analysis may be indicated. Unless seller is to be held to some duty vis-a-vis his buyer to settle the strike or to exert minimum efforts toward that end, performance must be considered impracticable. Assuming for the moment that strike per se renders performance impracticable, the seller will be excused only if the risk of the strike was on buyer, i.e., non-occurrence of the strike was a basic assumption of the contract. Three possible risk allocations exist: At one extreme, the risk could be placed on the seller as involving

229. During World War II many contracts contained so-called "escalator clauses" which made the price of the contract variable depending upon the costs of certain supplies. See Schroeder, The Impact of the War on Private Contracts, 42 MIcr. L. REv. 603, 607 n.11 (1944). Some current sales contracts contain a clause making the cost "subject to the usual demands of labor" or "higher wage scale." See Corona Coal Co. v. Robert P. Hyams Coal Co., 9 F.2d 361 (5th Cir. 1925). Such a contract is currently in use, relieving for "strikes or other labor disturbances (regardless of the reasonableness of the demands of labor). . . shortages of labor."

230. See UCC \& 2-615, comment 8.

231. See 6 WILliston, op. cit. supra note 188, $\$ 1931$ at 5411 : "The true distinction is not between difficulty and impossibility. ... The important question is whether an unanticipated circumstance has made performance of the promise vitally different from what should reasonably have been within the contemplation of both parties when they entered into the contract."

232. See text at note 217 supra.

233. UCC § 2-615, comment 4. 
a common business occurrence; at the other, the buyer could bear the risk, its occurrence being regarded as either unusual or as presenting a burden of such magnitude that distributing it among seller's buyers is the preferable course. The intermediate view would posit a duty on the seller to attempt settlement of the strike and treat seller's compliance with the duty as shifting the risk to buyer. Note that adoption of this view would make the determination of seller's compliance with a duty to seek settlement the central issue in ascertaining risk allocation as well as in deciding the impracticability question deferred above.

The common law is unsettled regarding the seller's duty to offer reasonable concessions to a striking or threatening union as a condition precedent to excuse. Cases permitting inquiry into the reasonableness of the concession reason that a claim of "impracticability" presupposes a showing that seller has made every reasonable effort to complete performance. 234 Other cases consider such an inquiry to involve "collateral" issues of labormanagement relations, and refuse to admit such evidence on the ground that an intricate policy analysis only remotely related to the contract in issue would be necessitated. ${ }^{235}$ Although strikes are more often to the employer-seller's disadvantage than to his advantage, a strict application of the latter approach is open to abuse. The buyer may be afforded necessary protection by a middle ground: Evidence may be admitted as to the seller's good faith with regard to the strike; if seller's sole object is to exert countervailing pressure on his employees, he should be excused, since the propriety of seller's labor relations is irrelevant to any duty owed buyer. However, if seller's non-settlement of the strike was prompted by a desire to escape from a bad bargain with buyer, the seller should not be excused. The reasonableness of a concession is not conclusive of seller's good faith. There is a two-fold statutory justification for a "good faith" determination. First, it seems reasonable to conclude that a basic assumption of the contract was that only those contingencies which occurred without a breach of seller's good faith were excusable. This inference is suggested by the comment to section 2-615. ${ }^{236}$ Second, section 1-203 specifically imposes an obligation of good faith in the performance of every contract.237

The above analysis seems to avoid the objection that the legal issue in the buyer-seller contract litigation depends upon an analysis of the rights and duties of an employer with respect to his employees. However, it seems that in practice the test may be difficult to apply. In the hypothetical

234. See, e.g., 6 Wrulston, op. cit. supra note $188, \$ 1951 \mathrm{~A}$ at 5465 \& n.6.

235. Id. \& 1951A n.7: "The trouble with approaching the problem upon this basis is that it places upon the court the burden of determining the issues of the strike, a task now being confided to administrative tribunals." See Delaware L. \& W. R.R. v. Bowns, 58 N.Y. 573 (1874) (seller should not be held to any greater obligation to prevent a strike when under contract of sale than he ordinarily would in the normal conduct of his business).

236. UCC \$ 2-615, comment 6 .

237. UCC \$ 1-203: "Every contract within this Act imposes an obligation of good faith in its performance or enforcement." The 1957 draft of the code includes the words ". . .or duty. . ." between "contract" and "within." 
case, although the union's demands seem reasonable and a compromise price seems relatively easy to ascertain in view of the labor contract settlements in the industry, as a practical matter a complex of factors could cloud predictability of settlement. Whether the seller would be liable should therefore depend primarily on buyer's ability to establish a bad faith motivation of seller. ${ }^{238}$

Excusing the seller when the disruptive contingency is destruction of his plant, if a manufacturer, or his crops, if a farmer, is a less complex problem. If impracticability is to be a defense in any instance, these situations would seem to qualify. No difficulty is experienced in finding the non-occurrence of these contingencies to be a basic assumption. ${ }^{239}$ Nevertheless, here too, excuse must be predicated on seller's good faith. Destruction must not have been intentionally caused by seller; this risk the buyer certainly cannot be said to have assumed. Similarly, a bad faith delay in restoring his ability to perform will preclude seller's claim of excuse.

The discussion thus far has premised that seller either cannot or need not obtain the goods necessary to satisfy the contract from a competitor. Since, if he were to do so, seller would probably have to pay his competitor the same price that buyer would pay in purchasing from seller's competitor, a requirement that seller supply the goods whenever physically possible would be placing the risk of loss on the seller. This further illustrates the significance of viewing the problem as one of allocation of risk rather than ability to perform. Excuse of seller in these circumstances may be doctrinally justified by claiming that production from seller's facilities was the basic assumption and that it was this "performance as agreed" that had been made impracticable.

\section{Failure of Seller's Source of Supply}

In conducting his affairs, seller may rely upon a particular source for supplying items needed to fulfill his contract with buyer. This source may supply (1) essential items used to prepare goods, including processing

238. If there is a clause in the contract which purports to relieve seller in case of strikes, a problem of interpretation may arise as to what constitutes a "strike." "Strikes" may include or exclude certain comparatively minor labor difficulties such as slowdown or refusal to perform a specific task. See New York Coal Co. v. New Pittsburgh Coal Co., 86 Ohio St. 140, 99 N.E. 198 (1912) (miners' refusal to work a dangerous portion of mine held not a "strike" within the meaning of contract clause). Many contracts currently in use relate to "differences with labor" or "labor disturbances."

239. The courts have been rather liberal in excusing such manufacturers, as well as farmers whose crops have been destroyed, and it would seem that such liberality would continue to exist under the terms of the code. See Ontario Deciduous Fruit Growers' Ass'n v. Cutting Fruit Packing Co., 134 Cal. 21, 66 Pac. 28 (1901); Tanner v. Childers, 108 Utah 455, 160 P.2d 965 (1945) ; Snipes Mountain Co. v. Benz Bros. \& Co., 162 Wash. 334, 298 Pac. 714 (1931) ; Howell v. Coupland, 1 Q.B.D. 258 (C.A. 1876); 6 WinlstoN, op. cit. supra note 188, \& 1948. But see A. L. Jones \& Co. v. Cochran, 33 Okla. 431, 126 Pac. 716 (1912) (holding that a grower who contracted to supply a specific quantity may not be excused when his crop failed, and evidence was excluded which would tend to show from the custom of the trade that when a grower's crop failed he is excused from full performance and may prorate among his customers). 
materials (such as compressed oxygen used in the manufacture of steel), or finished component parts (such as automobile bumpers); ${ }^{240}$ or (2) the actual goods purchased for resale (such as a merchant's stock of goods).

When seeking excuse for non-performance, middlemen have fared less well under pre-code law than farmers and manufacturers; impracticability is found to exist less frequently or exclusivity is not treated as a basic assumption. For example, in Sunseri v. Garcia \& Maggini Co. ${ }^{241}$ a middleman whose contract called for a delivery of garlic when the California crop was harvested was not excused when that crop failed, despite a contract provision purporting to relieve seller in cases of "crop failure." The court distinguished the dealer from a farmer, apparently assuming that the latter would have been excused; the middleman might have secured the garlic from a harvest elsewhere. Such a distinction would seem to have a reasonable policy basis. If the seller is a farmer or manufacturer, it is more likely that the parties expect the goods to come from the seller's land or factory than it is that a merchant will have but one source. Moreover, the farmer or manufacturer's loss would be heavy without the addition of damages for failure to deliver; ${ }^{242}$ insurance may not wholly reimburse him. The distributor's sole loss would be the difference between his originally anticipated purchase price and the amount he would have to pay his new supplier.

The difference in extent of the loss is a proper factor to consider. Possibly more important is the ability of the middleman to purchase the goods from another supplier for an amount less than his purchaser could, an advantage not always available to a producer when purchasing from a competitor. Thus a middleman's loss may not be as severe as would be his buyer's or a producer's. ${ }^{243}$

On the other hand, when a seller bears a loss it is anticipated that he will eventually pass it along to his purchasers, competition permitting. For this reason the seller's supplier, to whom seller's loss is traceable, may be excused, seller being considered better able to bear the risk. But these contingencies will not affect sellers alike; competition would likely prevent a compensating price increase by seller to his purchasers. Therefore, the seller will probably be unable to recoup his loss unless it is initially borne by his buyer. If seller must absorb the loss, the principle of risk distribution by which seller's supplier was excused tends to break down. ${ }^{244}$ Ac-

240. Similar events have recently occurred. Wall Street Journal, Jan. 29, 1957, p. 2, col. 2 (bumper factory strike cuts off supply to American Motors who cannot meet current orders). $I d$. at p. 3 , col. 1. (strike at oxygen plant injures steel, missiles, atomic energy industry).

241. 298 Pa. 249, 148 At1. 81 (1929).

242. See 6 WILLISTON, op. cit. supra note $188, \S 1931$.

243. See Note, The Fetish of Impossibility in the Law of Contracts, 53 ColuM. L. Rev. 94, 101-02 (1953).

244. In the case where seller's supplier has defaulted, the official comment suggests, although there is no express provision in the code, that the seller should assign to the buyer his rights against the defaulting supplier as a condition precedent to claiming excuse. UCC $\S 2-615$, comment 5 . It does not appear that contractual provisions re- 
cordingly, excuse should be equally available to producer and distributor alike. ${ }^{245}$ Although buyers may suffer thereby, the loss would probably be distributed among several, making the load easier to bear.

Of course, when excusing a middleman there should be some evidence that his buyer was aware that a given source of supply is a proper basis for excuse. Limits of good faith and reasonableness will prevent the seller's abuse of the code's excuse provisions. The middleman would be required to use reasonable efforts to secure his supply before excuse may be claimed. To illustrate this, the comment ${ }^{246}$ cites with approval the case of Canadian Industrial Alcohol Co. v. Dunbar Molasses Co. ${ }^{247}$ In that case the middleman-seller was to supply molasses to buyer "of the usual run" of a named refinery. When the refinery reduced production substantially below its previous usual level, seller was unable to obtain sufficient molasses from the refinery to supply buyer with all of the contract's requirements, and vainly sought to substitute molasses from a different source. Seller was held liable in damages since he had not taken reasonable efforts to make a binding contract with the refinery. In so holding, the court assumed that seller would have been excused if the refinery had been destroyed or its supply of sugar cut off by a failure of the sugar crop. The court reasoned that in those situations, unlike the instant case, diligence resulting in a binding contract would have been unavailing. Perhaps an unrealistic degree of "diligence" was expected of the middleman in the Dunbar case in requiring him to bind himself to a contract with the refinery when, on the basis of all prior experience, such a contract would ordinarily have been unnecessary. ${ }^{248}$ However, notwithstanding any doubts as to the Dunbar case, courts under the code should refuse to find that the performance of the seller is "impracticable" when the seller's laxity in omitting to secure a source of supply was without any commercial justification or is tantamount to a lack of good faith. ${ }^{249}$

quiring such assignment are an ordinary commercial practice in buyer-seller contracts, and pre-code cases do not reveal that such assignment heretofore has been held to be a condition precedent. Under the code's theme of flexibility and fairness, a court might, where a "windfall" to the seller seems likely, require an assignment to the buyer as a manifestation of the seller's good faith.

245. Professor Corbin has suggested that the terms of $\S 2-615$ makes that section applicable only to sales "between merchants," but that its broad coverage may well make it applicable to everyone. 6 CoRBIN, op. cit. supra note 198, $\$ 1339$ at 322 . There appears to be no indication that the terms of the section purport so to limit its applicability. In several other sections of the code a distinction is made when the seller is a "merchant." See UCC \$\$ 2-314 (implied warranty), 2-509 (risk of loss).

246. UCC \& 2-615, comment 5 .

247. 258 N.Y. 194, 179 N.E. 383 (1932). See Crown Embroidery Works v. Gordon, 190 App. Div. 472, 180 N.Y. Supp. 158 (1st Dep't 1920); Washington Mfg. Co. v. Midland Lumber Co., 113 Wash. 593, 194 Pac. 777 (1921).

248. The history of the prior dealings between the parties may be more persuasive under the code, since its use as evidence has received statutory sanction. See UCC $\S$ $1-205$.

249. See UCC $\S 1-203$. This problem has been obviated by competent drafting. See the contract in Amsden Lumber Co. v. Stanton, 132 Kan. 91, 294 Pac. 853 (1931): Seller not responsible for strikes, fires, "or other causes beyond the control of seller or shipper [seller's supplier].... [I]n the event the shipper shall at any time for any 
There remains the problem of whether a seller may "voluntarily" fulfill a contract from other sources when it conceded that continuance of a particular source which failed is a "basic assumption." This inquiry becomes highly significant when the market has fallen and buyer is searching for an argument to avoid an unfavorable contract with the seller. In such event section 2-615 seems unavailable to buyer in language and principle. Since seller is ready, willing and able to perform, his performance cannot be said to be impracticable. Furthermore, the section merely provides that "delay in delivery . . . is not a breach. . . ." The only indication that buyer may be excused under this provision appears in the comment. ${ }^{250}$ However, the comment refers to a situation in which there is a frustration of buyer's expectations, an instance clearly distinguishable from the present issue. Whether buyer can avoid performance by asserting that the use of an unauthorized source gave rise to his right to reject a delivery which fails "in any respect to conform to the contract" 251 is a problem beyond the scope of this examination and ably treated elsewhere. ${ }^{252}$

\section{Failure of Transportation Facilities}

During the 1930's frequent shortages of railroad cars prevented prompt coal deliveries. War conditions are a frequent cause of the termination of maritime service or transoceanic air shipments. Destruction of a specified ship, a pilots' strike on an agreed air service, or discontinuance by the.railroad of an agreed line may present issues of the seller's right or duty to use alternative means of delivery.

Such issues are identical to those posed by the problems of excuse heretofore discussed. Application of the relevant principles, however, involves the interrelationship of several code provisions. Under some circumstances the "seller may have assumed a greater obligation" than that provided by section 2-615. Assume that no means is available to transport cargo required by a contract to be shipped F.O.B. Havana from Cuba to the United States. The buyer can argue that the f.o.b. term was an assumption of greater obligation, by operation of law. Such a term means that buyer must bear the expense of shipment and the risk of loss. ${ }^{253}$ The code further provides that under an f.o.b. place-of-shipment term seller must "put the goods in the possession of a carrier" 254 and "bear the ex-

cause whatsoever be unable to make and ship cement in accordance with its agreements and orders, the shipper may determine, as nearly as practicable, the pro rata share of the cement of each of its customers. . .and may limit and reduce its shipments. . .according to seller's pro rata share."

250. UCC § 2-615, comment 9.

251. See UCC \& 2-601. (1949).

252. See Honnold, Buyer's Right of Rejection, 97 U. PA. L. REv. 457, 475-76

253. Revised American Foreign Trade Definitions-1941, 2 WrLliston, SALES $\$ 2801$ (j) (II) (E) (II-E) (1948).

254. UCC \& 2-504(a). 
pense and risk" of doing so. ${ }^{255}$ The determinative issue is whether this term places an absolute obligation on the seller to bear the risk of nonexistence of a carrier, or whether it presupposes the existence of the carrier as the only instance in which the duty is operative. ${ }^{256}$ The former interpretation would excuse the seller only when the contract expressly provided that the risk of non-availability was on the buyer. Since there is nothing to suggest that the code's draftsmen so regarded the problem, nor is there any reason for so distinguishing this case from other instances of impracticability, this interpretation should be rejected in favor of the latter, recognizing excuse even in the absence of an express provision. Hence, under the code, which does not specifically mention this situation, it seems that no special rule is applicable, unlike the pre-code cases which tended to be strict in holding that sellers were under a duty to perfect transportation arrangements. ${ }^{257}$

When an agreed transportation facility is not available but a commercially reasonable alternative is, section 2-614 requires substitution of the latter. In principle, as previously mentioned, this requirement seems fair and is consistent with the recent trend of cases denying excuse when matters merely incidental to, as opposed to those going to the heart of, the agreement have failed. ${ }^{258}$

\section{Government Regulations ${ }^{250}$}

\section{Licensing Requirements}

Assume that seller contracted to supply buyer with whiskey. At the stipulated time for delivery the market has risen and seller refuses to per-

255. UCC \& 2-319(1)(a); see also Madeirense Do Brasil S/A v. Stulman-Emrick Lumber Co., 147 F.2d 399 (2d Cir. 1945).

256. The code imposes an obligation on seller to find a carrier and make an adequate contract when other terms such as C.I.F. and C.\&F. appear in the contract. UCC $\S 2-320(2)(\mathrm{a})$.

257. See, e.g., Madeirense Do Brasil S/A v. Stulman-Emrick Lumber Co., 147 F.2d 399 (2d Cir. 1945) ; Jessup \& Moore Páper Co. v. Piper, 133 Fed. 108 (C.C.E.D. Pa. 1902); Haigh Hall S.S. Co. v. Andersen, 246 Mass. 34, 140 N.E. 302 (1923). But cf. Texas Co. v. Hogart Shipping Co., 256 U.S. 619 (1921) (performance of a charterparty excused when specific ship requisitioned by British Government during war).

258. See note 205 supra.

259. Problems presented by an intervening governmentally imposed ceiling price are deceptively similar to those of impracticability. Assume that seller has agreed to supply buyer with certain goods at $\$ 2.00$ per unit. After formation of the contract and before performance, a government agency orders a ceiling price of $\$ 1.75$ per unit. Since the regulation provides the buyer with more favorable treatment than did the contract, there is no reason for its promulgation to terminate his obligation if seller attempts to enforce the contract at the lower price. Matter of Joseph Jacobs and Pacific Mills, 280 App. Div. 326, 113 N.Y.S.2d 540 (1952), 52 Colvar. L. Rev. 940. Performance of the contract at $\$ 2.00$ now being prohibited by law, the buyer may seek to force the seller to perform at $\$ 1.75$. (This assumes that there is no specific provision in the order or statute which exempts contracts entered into before its promulgation. For an excellent discussion of the relation of the specific statutory provisions to sales contracts, see Brown \& Rubin, The Effect of Wartime Price Controls on Contracts For the Sale of Goods, 52 Y ALE L.J. 74, 77 (1942)). It is submitted that seller would not be forced to perform at the lower figure regardless of practicability. See Matter of Kramer \& Uchitelle, Inc., 288 N.Y. 467, 43 N.E.2d 493 (1942). Analytically the only 
form, claiming that he is unable to sell either because he never had a license or because the Liquor Control Board recently revoked his license.

The code provides that seller will be excused for impracticability due to ". . . compliance in good faith with any applicable foreign or domestic governmental regulation or order whether or not it later proves to be invalid." 260

On first impression the code provision might seem to have the astounding effect of excusing a seller for omission to obtain a license. Pre-code cases, however, have generally held that the risk of obtaining a license is on the seller. ${ }^{201}$ The code's "good faith" requirement would probably preclude a claim of excuse by sellers who have knowledge of the license requirement, although those who contract without such knowledge would seem to be excused. ${ }^{262}$ While it may be said that public policy demands that persons should not be faced with the temptation of violating the law in order to avoid civil liability, ${ }^{263}$ commercial policy would seem to demand that a seller who holds himself out as qualified to sell goods should be required at his peril to discover any governmental duties. ${ }^{264}$ The code's emphasis on commercial expediency might persuade a court to hold that a seller's failure to discover an applicable existing governmental disability would be tantamount to a lack of "good faith."

When the seller's license is revoked, he would appear to be excused. Should the revocation order ultimately be held invalid, non-performance in the interim would also be excused. This provision is a clear rejection of a much criticized Supreme Court decision ${ }^{265}$ and should contribute to the

instance of impracticability arises when the seller seeks to enforce performance of the contract at the original price; since such performance would be, by hypothesis, illegal, it is presumed to be impracticable. See Matter of Kramer \& Úchitelle, Inc., supra at 472,43 N.E.2d at 497. On the other hand, when the buyer attempts to force a sale at the lower intervening ceiling price, an impracticability situation is not presented. In an impracticability case seller is seeking to be excused from his otherwise enforceable promise; here the buyer is asking that seller perform at a price to which he never agreed. Such a case would be excluded from the operation of UCC \& 2-615 which refers to ". . performance as agreed. . ..." (Emphasis added.)

260. UCC \& 2-615(a).

261. Unless the terms of the contract specifically make delivery contingent upon seller's obtaining a license. See 6 CoRBIN, op. cit. supra note 198, § 1347. able.

262. The court would probably require that seller's lack of knowledge be reason-

263. Cf. RESTATEMENT, CoNTRACTS $\$ 512$ (1932).

264. But see Anglo-Russian Merchant Traders v. Batt, [1917] 2 K.B. 79 (excusing seller's promise when license to export could not be obtained even though seller's promise seemed absolute on its face, and both parties knew that a license was required. The court refused to find an "absolute obligation to do that which the law forbids." Accordingly, the contract was construed to be an obligation only to use seller's best efforts). See Brown, The Effect of Conscription of Industry on Contracts for the Sale of Goods, 90 U. PA. L. REv. 533, 558 (1942). It is submitted that the AngloRussian case would be reversed under the code.

265. Northern Pacific Ry. v. American Trading Co., 195 U.S. 439 (1904). The code provides for seller's excuse when performance has been made impracticable "by compliance in good faith with any applicable foreign or domestic governmental regulation or order whether or not it later proves to be invalid." UCC \& 2-615 (a). Professor Corbin has criticized the Northern Pacific case and suggested that the opposite result would be reached under the code; however, the Northern Pacific case has never been overruled. See 6 CoRBIN, op. cit. supra note 198, \$1346 n.41. 
certainty of business transactions by ending speculation concerning the validity of regulations as affecting liability for non-performance. As applied to excuse a seller who was not at fault in the license revocation, ${ }^{266}$ the code provision seems manifestly sound. But a seller whose license is correctly revoked because he had abused the privilege it provided should not be permitted to take advantage of his own wrong and shift a loss to his innocent buyer. Pre-code cases recognized this limitation, ${ }^{267}$ and it would seem that a court should interpret the code's "good faith" requirement as denying excuse to a seller in such a case. ${ }^{268}$

\section{Government Pre-Emption of Seller's Output}

Assume that manufacturer $S$ is currently producing 300 cases of ammunition per month and is under contract to supply each of six distributors monthly with 50 cases of ammunition at $\$ 50$ per case. Subsequently, the United States Government enters into a "mandatory" 269 contract with S requiring him to supply the Government with 300 cases per month at $\$ 60$ per case. Although S's maximum plant potential is 400 cases per month, $S$ purports to cancel his contracts with the six distributors and ships his entire monthly output to the Government.

Conceding that S has "complied in good faith" with the governmental order, the distributors would argue that performance on their contracts has not been made "impracticable," at least to the extent of S's unused production capacity of 100 additional cases per month. Furthermore, they would urge that $S$ be required to expand his capital facilities to fulfill all the contracts even if such a requirement should produce a financial loss, contending that operating at a loss does not ipso facto render performance "impracticable."

"Impracticability" for this purpose might be determined by considering whether a reasonable businessman would expand his present facilities to meet the needs of an additional non-government ${ }^{270}$ contract. Thus, if the idle plant capacity could be utilized without causing an increase in cost that would exceed the increased revenue from the new contract, the court

266. See Louisville \& Nashville R.R. v. Crowe, 156 Ky. 27, 160 S.W. 759 (1913); Jersey Ice Cream Co. v. Banner Cone Co., 204 Ala. 532, 86 So. 382 (1920). $\S 1939$.

267. 6 CoRBIN, op. cit. supra note 198, § 1346; Williston, op. cit. supra note 253 ,

268. Unlike the Restatement of Contracts ( $\$ 458$ ), the code excuses performance made impracticable by compliance with foreign regulations as well as domestic regulations. While we have no interest in protecting the laws of another country (aside from motives of comity), often such regulations would result in factual impracticability. Analyzed in terms of actual impracticability, the inclusion of the code provision seems commercially sound. See Note, The Fetish of Impossibility in the Law of Contracts, 53 ColuM. L. REv. 94, 99 (1953).

269. This would probably be done pursuant to a "conscription" or "priority" statute enacted to deal with certain constitutionally justifiable contingencies such as war. See Brown, supra note 264, at 534-51.

270. For purposes of the "impracticability" test, the hypothetical contract referred to is a private contract so as to avoid the complications created by the mandatory nature of government contracts. 
probably would not consider performance wholly "impracticable," but rather would apply section 2-615(b) to require allocation among seller's customers of that part of the agreed performance which remains practicable. As applied to the hypothetical case, the court might require seller to expand the physical potential of his plant up to its theoretical maximum if the government contract plus pro rata performance on the private contracts will yield the seller a net return which is equal to or greater than the net return that would have been realized on complete performance of the contracts with the distributors. ${ }^{271}$ If the contract with the Government had been made voluntarily, the seller would undoubtedly be required to perform on the distributors' contracts even at a staggering loss. But where mandatory government action has upset a previous transaction, it would seem unreasonable to require seller to expand his capacity to perform under the previous contract if to do so would cause him a net loss.272

A seller who desires to operate at less than plant potential in an industry which is sensitive to government requisitions would be well advised to adopt a contract clause that would permit an increase in his plant potential only at his option. Of course, buyers in such an industry should, to the extent of their bargaining power, attempt to insert a clause binding the seller absolutely to deliver even at a loss.273

\section{Procedure Upon Claim of Excuse}

Any statute establishing standards for excuse from contract performance must provide directions by which, after disruption of normal commercial procedures, business affairs may be adjusted as efficiently and as certainly as possible. Sellers, in order to make plans for future operations, must know their obligations regarding stockpiled goods and any partial production which might become available. Buyers must know whether they may depend upon sellers' ability to make part performance, especially when substitute deals might be necessary before price fluctuations compound

271. Increased production from expanded facilities may produce a net return to seller which is greater than the return from the buyer's contract alone but less than the return on the government contract alone; e.g., (1) $\$ 10,000$ on B's contract if no government contract is involved; (2) $\$ 20,000$ on the government contract if no buyer contract is involved; and (3) $\$ 15,000$ on both contracts if $S$ is required to expand his facilities. Note also that it is likely that $S$ who has been required to increase capital expenditures might have subsequent use for such capital. It would seem that the liklihood of such use would be relevant evidence.

272. The foregoing test has the support of some writers. See 6 ConBIN, op. cit. supra note 198, $\$ 1345$ n.24; Note, Effect on Contracts of War Orders or Other Acts of State, 28 YALE L. J. 399, 400 (1919).

273. Note that under pre-code law seller's claim of excuse was not jeopardized by the fact that he had actively solicited government requisition action. Nitro Powder Co. v. Canadian Car \& Foundry Co., 233 N.Y. 294, 135 N.E. 507 (1922). Arguably the code requirement of good faith would suggest an opposite result.

In 1939 Congress passed the well-known "No Damage Statute." 54 Stat. 676 (1939), as amended, 50 U.S.C. \$1152(4) (1952): "No person, firm or corporation shall be held liable for damages or penalties for any default under any contract or order which shall result directly or indirectly from his compliance with any rule, regulation, or order issued under this section." 
buyers' losses and while other production sources are available. In two sections the code seeks to afford a reasonably certain yet flexible procedure to safeguard the needs of both buyers and sellers. Section 2-615(b) and (c) provides for notice to buyers of seller's non-performance or part performance and for seller's allocation of part performance among them. Section 2-616 grants buyers certain options upon receipt of such notice. These provisions will be considered in terms of their impact first upon sellers and then buyers.

\section{Pro Rating the Available Supply}

When, for example, the seller's plant is destroyed there is no immediate problem of giving buyers a proportionate share of his production. But suppose that seller has some warehoused goods or that only part of his productive ability is halted. For this situation the code requires that seller notify buyer of the delay or non-delivery ${ }^{274}$ and allocate his available goods in "any manner which is fair and reasonable." ${ }^{275}$ Since the code recognizes modification of this requirement only insofar as "seller may have assumed a greater obligation," the seller's duty to notify and prorate may not be avoided by a contract term. ${ }^{276}$ Such an interpretation also seems compelled by independent judgment, considering the potential hardship to which excusing the seller might subject an innocent buyer and the consequent dictate in fairness that seller make every effort to ease this burden; certainly business sagacity would concur.

Aside from commanding that the allocation among customers be "fair and reasonable," 277 the code specifies only that the seller may elect to include those regular customers who are not then under contract.278

274. UCC \& 2-615(c).

275. UCC § 2-615(b).

276. Section 2-616(3), in describing the buyer's prerogative either to accept partial shipment or to terminate the entire deal, commands that "the provisions of this section may not be negated by agreement except in so far as the seller has assumed a greater obligation under the preceding section." If the seller were permitted to negate the notice or allocation provision of $\S 2-615$, he would be undermining the purpose of $\S$ 2-616: to insure that the buyer will at the time of excuse have a free opportunity to modify the contract to accept partial shipment or to reject all subsequent shipments by the seller.

277. Fairness and reasonableness are subject to the scrutiny of the court and can be determined by resort to custom. Consolidation Coal Co. v. Peninsular Portland Cement Co., 272 Fed. 625 (6th Cir. 1921); Amsden Lumber Co. v. Stanton, 132 Kan. 91, 294 Pac. 853 (1931); see also UCC \$ 1-205.

278. Proration of output in cases of impracticability has been required by many cases. See, e.g., Consolidation Coal Co. v. Peninsular Portland Cement Co., 272 Fed. 625,630 (6th Cir. 1921) ("Plaintiff. . .can scarcely be presumed to have thought that its contract was the only one defendant had. . .."); Jessup \& Moore Paper Co. v. Piper, 133 Fed. 108 (C.C.E.D. Pa. 1902). Many contracts contain an allocation provision. See, e.g., contracts currently in use (note 188 supra); Diamond Alkali Co. v. Henderson Coal Co., 287 Pa. 232, 134 Atl. 387 (1926); Ranney-Davis Mercantile Co. v. Shawano Canning Co., 111 Kan. 68, 206 Pac. 337 (1912). See also Picklands, Mather \& Co. v. H.A. \& D.W. Kuhn \& Co., 8 F.2d 704 (6th Cir. 1925) (providing for a specific mathematical percentage of output in the event seller is unable to fulfill the entire contract). The code's option to include regular customers "not then under contract" has been recognized by some pre-code cases and rejected by others. Com- 
Several bases for allocating available goods appear reasonable, although the fairness of all is less certain. Initially, giving equal treatment to each customer seems as reasonable a method as any. However, if present and/or past orders indicate that certain buyers have purchased significantly more goods than others, because of either their greater reliance on seller as a supplier or their larger scale operations, it does not seem equitable now to make available to such buyers only the same share of goods as the others. Allocation in a ratio based on the physical volume of goods ordered is also reasonable. The standard could be total goods now on order or these together with past orders. Whether a customer presently has a large or small order, or perhaps even no order for goods with the seller, the commercial inconvenience- and perhaps the loss-he would suffer from termination of his supply is the same as that resulting to any other customer. Since the volume of goods on order at any particular time is dependent primarily on the customer's purchasing pattern, which may be unrelated to the injury he would sustain, it seems fair to include past experience when allocating. ${ }^{279}$ At the same time, allocating goods on the basis of present unfilled orders also seems fair, since each buyer would then receive a share proportionate to the supply which he sought to assure and which he obligated himself to take at a particular price. Under the code provision permitting any alternative which is "fair and reasonable," either of the last two methods of allocation seems authorized and in some situations equal shares would also be proper. Obviously the allocation requirement was inserted to protect buyers from the whims of their sellers. Accordingly, allocating goods to buyers who are selected arbitrarily or those who offer a more favorable price or other advantage to seller seems inconsistent with the draftsmen's intention. The code as enacted in Pennsylvania has no specific provision permitting the seller to allocate part of his available goods for his own manufacture. In a supplement to the code, however, the official uniform draft of subsection (b) has since been amended to give the seller an option to include "his own requirements for further manufacture." 280 The draftsmen maintain that the addition was designed only "to make it clear" that the seller could exercise such an option, but the implication previously seemed more non-existent than merely unclear. Considering the Pennsylvania version alone, a court could well conclude that the seller is without authority to allocate part of his production for his own needs. This is, of

pare B.P. Ducas Co. v. Bayer Co., 163 N.Y. Supp. 32 (Sup. Ct. 1916), with, Sandusky Cement Co. v. A. R. Hamilton \& Co., 287 Fed. 609 (6th Cir. 1923). See also Garfield \& Proctor Coal Co. v. Pennsylvania Coal \& Coke Co., 199 Mass. 22, 84 N.E. 1020 (1908).

279. See Corrin, op. cit. stipra note 198, § 1342. See also UCC \$ 2-615, comment 11 In Diamond Alkalai Co. v. Henderson Coal Co., 287 Pa. 232, 134 Atl. 387 (1926), the court apparently was sensitive to the possibilities of abuse by the seller, and refused to permit the seller to appropriate the usual percentage of his coal output to run-of-themine for spot orders (which presumably were bringing a higher price than his contract orders).

280. UCC \& 2-615(b), 1957 DRAFT. 
course, a harsh result; it may be supported because of the possible hardship which seller's excuse has caused to his innocent buyers. A more equitable procedure would include consideration of the seller's needs; however, whether that result may be accomplished within the present statutory framework depends on the courts' willingness to accept the draftsmen's suggestion that it was implicit. At least it is clear that the seller would not be permitted to use some of his remaining goods for his own manufacturing needs if this element of his business had not been established previous to the unforeseen event. This would follow from the basic inequity of preferring a new venture of the seller over the needs of relying buyers. ${ }^{281}$

\section{The Buyer's Prerogatives}

The buyer must, as already mentioned, ${ }^{282}$ receive notice from the seller as a prerequisite for the latter's claim of excuse. Provision is made for the buyer's alternatives in such event: He may, on written notification to the seller, modify the contract by agreeing to take his allocated portion; or instead he may terminate the contract or permit it to lapse by his inaction or silence. ${ }^{283}$ The code provisions are manifestly designed to prevent the seller from forcing the buyer to accept goods long after the originally contemplated time of delivery. A contract clause not uncommon in sellers' order forms, which is intended to accomplish such coercion, ${ }^{284}$ is made ineffectual under the code; section 2-616(3) provides that the aforementioned provisions "may not be negated by agreement except in so far as the seller has assumed a greater obligation. ..."

It is important to note that the code grants buyer these options in only two instances: where he receives notification of a "material or indefinite" delay, or of an allocation that is justified under section 2-615. ${ }^{285}$ On

281. UCC \& 2-615, comment 11.

282. See text at note 274 supra.

283. UCC \& 2-616: "(1) Where the buyer receives notification of a material or indefinite delay or an allocation justified under the preceding section he may by written notification to the seller as to any delivery concerned, and where the prospective deficiency substantially impairs the value of the whole contract under the provisions of this Article relating to breach of installment contracts (Section 2-612), then also as to the whole, (a) terminate and thereby discharge any unexecuted portion of the contract; or (b) modify the contract by agreeing to take his available quota in substitution. (2) If after receipt of such notification from the seller the buyer fails so to modify the contract within a reasonable time not exceeding thirty days the contract lapses with respect to any deliveries affected. (3) The provisions of this section may not be negated by agreement except in so far as the seller has assumed a greater obligation under the preceding section."

284. Such a clause might read as follows: "The seller shall not be liable for any delay in manufacture or delivery [due to enumerated causes]. . . and the existence of such causes of delay shall justify the suspension of manufacture, and, shall extend the time of performance on the part of the seller to enable it to make delivery in the exercise of reasonable diligence after the causes of delay have been removed. If the performance of the contract by the seller be delayed by reason of any of the causes above mentioned, the purchaser may, subject to previously obtaining the consent of the seller, cancel the purchase...."

285. UCC § 2-616(1). 
receipt of an allocation notice, while buyer may desire to have delivered as much of seller's goods as are available, he will not wish to do so at the expense of waiving any rights he might have against the seller for breach of contract. Since seller's tender of partial performance may be asserted as justified under the excuse provision, if buyer wants to accept or reject partial delivery he should be careful to make clear that he hás not waived his rights against the seller by acknowledging seller's right of excuse. A more significant problem is the determination of when delay will be considered "material or indefinite." Presumably, the courts will rely upon pre-code precedent in handling this question. In those cases the test was usially whether the delay had essentially altered the obligations of either party, but a common problem involved the time at which the question was to be determined.286 Some cases held that the critical time was when performance ultimately became practicable, others ruled that the burden must be assessed as it reasonably appeared at the inception of the contingency. 287 Since a specific time period will present inequities of its own, a flexible standard-even with its lack of certainty-is a wiser choice.

\section{Buyer'š Excuse When Contract Has Lost Its Ultimate Vălue: Frustration}

The 'code has no provision explicitly relieving the buyer who; by reason of a development not mentioned in the buyer-seller contract, has found it impracticable to perform. The impracticability section of the code provides only for the excuse of seller. ${ }^{288}$ It seems, therefore, that pre-code law would be consulted to "supplement" the code in the case of the buyer's claim of excuse. 289 The parallel doctrine of "frustration" where an unforeseen contingency basically disrupts buyers' ability to perform has been recognized by several American cases ${ }^{290}$ and by the Restatement, 291 but

286. Compare Dant \& Russel, Inc. v. Grays Harbor Exportation Co., 106 F.2d 911 (9th Cir. 1939), Edward Maurer Co. v. Tubeless Tire Co., 272 Fed. 990 (N.D. Ohio 1921), aff'd, 285 Fed. 713 (6th Cir. 1922), Normandie Shirt Co. v. J.H. \& C.K. Eagle, Inc., 238 N.Y. 218, 144 N.E. 507 (1924), Metropolitan Water Bd. v. Dick, Kerr \& Co., [1918] A.C. 119, werth, Corona Coal Co. v. Robert O. Hyams Coal Co., 9 F.2d 361 (5th Cir. 1925), Acme Mfg. Co. v. Arminius Chemical Co., 264 Fed. 27 (4th Cir. 1919).

287. See, e.g., Pacific Trading Co. v. Louisiana State Rice Milling Co., $215 \mathrm{La}$ 1086, 42 So.2d 855 (1949) (adopting the latter view); Comment, 48 MrcH. L. Rev. 872 (1950). Wartime contingencies and regulations might involve different policy considerations than the postponement-cancellation problems created by normal commercial hazard such as strikes. Compare Brown, The Effect of Conscription of Industry on Contracts for The Sale of Goods, 90 U. PA. L. REv. 553, 550-51 (1942) (government regulation requires only postponement), with, McELROY, IMIPOSSIBIITY OF PERFoinsANCE 175-76. (1941).

288. UCC \& 2-615.

289. "Unless displaced by the particular provisions of this Act, the principles of law and equity. . . shall supplement its provisions." UCC \$ 1-103.

290. See, e.g. La Cumbre Country Club v. Santa Barbara Hotel Co., 205 Cal. 422 , 271 Pac. 476 (1928) ; Alfred Marks Realty Co. v. Hotel Hermitage Co., 170 App. Div.; 484; 156 N.Y. Supp. 179 (2d Dep't 1915) ; Alfred Marks Realty Co. v. "Churchills,"; 90 Misc. 370, 153 N.Y. Supp. 264 (Sup. Ct. 1915).

291. Restatement, Contracts $\$ 288$ (1931). 
it has been extremely limited ${ }^{292}$ and its existence as an American doctrine has been questioned. 293

A comment to the code suggests that the impracticability section of the code might entitle the buyer to an exemption where, "in reasonable commercial understanding," the contract is conditional upon a specific venture. ${ }^{294}$ However, the draftsmen also indicate that giving notice to seller that the supplies are needed to fill "a specific contract of a normal commercial kind" is not sufficient to excuse the buyer if that contract is terminated. ${ }^{295} \mathrm{Un}$ fortunately, no clear standard is provided for delineating contracts which are commercially understood to be conditioned on continuance of the buyer's needs from those which are not. Presumably a specific reference in the buyer-seller contract to reliance on a particular state of facts would achieve this result. But in that case, of course, no reference need be made to the code's excuse provision, for the contract itself would permit termination of buyer's obligation.

\section{CoNCLUSION}

The code's unprecedented statutory treatment of the problems of impracticability has presented the businessman and commercial lawyer with a brief, concise, and rather broad codification of an unwieldly mass of case law. In theory, at least, the draftsmen of the code were prudent in couching the impracticability provisions in broad rather than detailed terms, thus permitting the court in each case to exercise a degree of discretion guided by the code's premises of fairness and commercial reasonableness.

In practice, the impracticability provisions should work to the advantage of commerce. Although some of the code's terms are unfortunately

292. The buyer has not been excused from accepting delivery when there has been a severe drop in his market. W. H. Edgar \& Son v. Grocers' Wholesale Co., 298 Fed. 878 (8th Cir. 1924) (The court in this case specifically left open the question of the buyer's obligation in time of general panic). Moreover, a general depression will not excuse buyer even when a force majeure clause purported to relieve buyer for failure to accept due to unforeseen circumstances. See Swift \& Co. v. Columbia Ry., 17 F.2d 46 (4th Cir. 1927); Cleveland \& Western Coal Co. v. Cyclops Steel Co., 278 Pa. 346, 123 At1. 320 (1924) (crop shortage not proximate caúse); Western Alfalfa Milling Co. v. Worthington, 31 Wyo. 82, 223 Pac. 218 (1924) ; Conger v. Italian Vineyard Co., 186 Cal. 404, 199 Pac. 503 (1921) (A wine-maker was not excused from his promise to take product $A$ when the Government has imposed an almost prohibitive tax on product $B$ which is a necessary ingredient to his production of $A$ ).

293. See Anderson, Frustration of Contract-A Rejected Doctrine, 3 DE PAUL I. REv. 1 (1953).

294. UCC \& 2-615, comment 9. Express clauses purporting to relieving buyer have been given effect only when the draftsman has taken great pains to make the language unquestionably clear. Compare the successful clause in International Paper Co. v. Beacon Oil Co., 290 Fed. 45, 46 (1st Cir. 1923) ("Neither party shall be responsible for delays. . due to any cause beyond its control, wheresoever arising. . . whether or not the cause of the same class as those enumerated above, such enumeration being expressly understood to be in nowise exclusive of other causes or classes of causes. ..."); zeith, the unsuccessful contract in Baetjer v. New England Alcohol Co., 319 Mass. 592, 595,66 N.E.2d 798, 800 (1946) ("Buyer shall not be liable for failure to take delivery of the molasses purchased hereunder for any of the above causes which would prevent Buyer's vessel from accepting delivery.").

295. UCC \$ $2-615$, comment 9. 
subject to a considerable latitude of interpretation, the code's rules should promote greater certainty for many transactions.

The code provisions have not dramatically altered the substance of pre-code law. But in many cases changes do result, and these changes should more closely achieve commercial expediency and fairness.

\section{PART IV. TRAFFIC IN CONTRACT RIGHTS AND DUTIES-ASSIGNIMENT AND DELEGATION}

At early common law, choses in action were not assignable. ${ }^{296}$ This prohibition has been attributed to the policy of discouraging the offense of maintenance. ${ }^{297}$ Modern writers, however, have ascribed the rule to the common law's conception of a chose in action as a personal right which, in its very nature, ${ }^{298}$ was not transferable. ${ }^{299}$

This early rule has long since been discarded by the common law..$^{300}$ It is now accepted that ". . . public policy favors the assignability of contracts as facilitating commerce and its complex transactions. . . ." 301 The Uniform Commercial Code recognizes both the assignment of rights and the delegation of performance as normal and permissible incidents of a contract for the sale of goods. ${ }^{302}$

296. 2 WILLISTON, Contracts $\$ 495$ (Williston and Thompson ed. 1936); Ames, The Desseisin of Chattels, 3 HaRv. L. REV. 337 (1890).

297. 2 Williston, op. cit. supra note $296, \S 405$.

298. According to Ames, the rule that choses in action could not be assigned was a "principle of universal law." Ames, supra note 296, at 339. This was refuted by Cook, who expressed the view that assignability was purely a question of positive law. Cook, The Alienability of Choses in Action, 29 HARv. L. REv. 816, 818 (1916).

299. 4 Corbin, Contracrs $\S 856$ (1951) ; 2 Williston, op. cit. supra note $296, \S$ 405 ; Cook, supra note 298.

300 . The courts first gave effect to assignments of choses in action by implying the creation of a power of attorney in the assignee to sue in the name of the assignor. 4 Corbin, op. cit. supra note 299; Cook, supra note 298, at 822 . However, unlike a true power of attorney, the creator of the power could not release the obligor once the obligor had been notified of the creation of the power. Carrington v. Harway, 1 Keble 803, 83 Eng. Rep. 1252 (K.B. 1676). Statutory reforms in judicial procedure requiring that suits be brought in the name of the "real party in interest" and combining law and equity into a uniform judicial system have also played an important part in establishing the power to assign contract rights. See Corbin, op. cit. supra note 299.

301. Gargiulo v. California Wineries \& Distilleries, 103 Misc. 691, 696, 171 N.Y. Supp. 855, 857 (Sup. Ct. 1918).

302. UCC 2-210, comment 1. The only state to thus far adopt the UCC is Pennsylvania. Pa. Stat. AnN. tit. 12A (Purdon 1954). Both articles 2 and 9 of the code, the Sales article and the Secured Transactions article respectively, set forth specific rules to govern the assignment and delegation of contractual obligations. These rules would seem to be complementary: article 2 applies to transactions in goods except where the purpose of the transaction is to create a security arrangement. (Security arrangement transactions are specifically excluded from the coverage of the Sales article by UCC $\$ 2-102$. A proposed amendment to this section would limit the scope of article 2 solely to transactions for the sale of goods. UCC \& 2-102 (Supp. 1955)). Where a security arrangement is intended or there is a financing sale of accounts, contract rights or chattel paper (A proposed amendment would eliminate the requirement that such sales be "financing," UCC $\$ 9-102$ (1) (b) (Supp. 1955)) the precepts of 
Underlying the code's treatment of assignment is the assumption that limitations on the power to transfer contract rights restrict commercial activity. The draftsmen accordingly have endeavored to expand the power to assign rights in certain commercially important situations. These assignment provisions will be examined in the first section of this part. The second section will discuss the code's rules on delegation of duties which reflect the code's premise that the essential purpose of a commercial contract $^{303}$ is actual performance rather than the right to win a lawsuit. Thereafter consideration will be given to whether the assignor and the obligor of a contract can independently modify their agreement after the obligor has been notified of the assignment, a problem receiving special attention in the code.

\section{ASSIGNMENT of RightS}

Both the common law ${ }^{304}$ and the code permit assignment of contract rights so long as the assignment will not unduly burden the obligor of the right transferred. Section 2-210(2) provides:

"Unless otherwise agreed all rights of either seller or buyer can be assigned except where the assignment would materially change the performance of the other party. . . ."

\section{Contract Terms Prohibiting Assignment}

A significant departure from existing contract theory ${ }^{305}$ is presented by the code provisions which permit assignment of certain rights notwithstanding contract terms prohibiting their assignment. As to rights which are no longer executory, section 2-210(2) states:

"A right to damages for breach of the whole contract or a right arising out of the assignor's due performance of his entire obligations can be assigned despite agreement otherwise."

article 9 control. UCC $\S \S 9-102(1)$ (a), (b). The Sales article provisions on assignment are contained in $\$ 2-210$. According to the official comment the "... .section is not intended as a complete statement of the law of delegation and assignment but is limited to clarifying a few points doubtful under the case law." UCC 2-210, comment 7. The principle corresponding section in article 9 is $9-318$; this, however, is not the only section of article 9 which affects the law of assignment. Section 9-206 treats agreements not to assert defenses against assignees and the rights of an assignee where the assignor defaults are set forth in $\S 9-502$. The latter two sections will not be considered in this Note.

303. UCC 2-609, comment 1.

304. Restatement, Contracts $\$ 151$ (a) (1932).

305. RESTATEMEAT, CONTRACTS \& 151 (1932): “A right may be the subject of effective assignment unless, (c) the assignment is prohibited by the contract creating the right." It has been contended that statutes making choses in action freely assignable and requiring that suits be brought by the real party in interest operate to prevent the restricting of the power of assignment. This argument has been rejected, it being held that such statutes merely permit assignment and do not prevent voluntary limitations on assignment. Allhusen v. Caristo Constr. Corp., 303 N.Y. 446, 103 N.E.2d 891 (1952). 
For transactions coming within the purview of article 9, section 9-318(4) provides: "A term prohibiting assignment of an account or contract right is ineffective. ..." 306

Since an "account" is defined as a "right to payment for goods sold or leased or for services rendered," ${ }^{307}$ it is also within those covered by section 2-210(2), as the comment to that section recognizes. ${ }^{308}$ A "contract right," however, being a "right to payment . . . not yet earned by performance," 309 is still executory; hence, as to such rights, section 9-318(4) extends the assignment power beyond the scope of section $2-210(2) .{ }^{310}$ The result is that the only rights arising out of a contract to which neither of these provisions will apply, thereby making non-assignment terms enforceable, are those, other than the right to payment, not yet earned by performance and those to which article 9 specifically does not apply. The latter include, for this purpose, only an employee's right to compensation ${ }^{311}$ and a businessman's right to payment, if not yet earned by performance, on accounts transferred either as part of a sale of the business which produced them or together with a delegation of duty to perform under the contract. $^{312}$

Prior law was not uniform with regard to the effect to be given terms restricting assignment. The question has arisen usually where an obligor advanced the restriction as a defense to a suit by an assignee. Frequently the courts, by interpreting the restraint as not applying to the particular assignment in dispute, were able to enforce the assignment without passing upon the validity of the restriction. ${ }^{313}$ Provisions which, in general terms, prohibit assignment of the contract have been interpreted as preventing only the delegation of a party's duties. ${ }^{\mathbf{3 1 4}}$ Even where limitations were clearly applicable to rights, as distinguished from duties, courts have construed

306. In contrast with the provisions referred to in the text is the code's treatment of assignments of the right to draw on a documentary letter of credit. UCC \& 5-115 provides that the right to draw on a credit can be assigned only on the express authorization of the issuer and that, unless otherwise agreed, the issuer notwithstanding notice of an assignment, "may still recognize and honor a draft drawn by the original beneficiary of the credit without being liable to the assignee. This provision is criticized in Gilmore, The Commercial Doctrine of Good Faith Purchase, 63 YALE L.J. 1056, 1108-18 (1954).

307. UCC \& 9-106.

308. UCC \& 2-210, comment 3.

309. UCC \& 9-106.

310. See UCC \& 2-210, comment 3.

311. UCC \$ 9-104(d). Section 2-210(2) would not be applicable as article 2 covers only contracts for the sale of goods. UCC \& 2-102 (Supp. 1955).

312. UCC \& 9-104(f).

313. Francis v. Ferguson, 246 N.Y. 516, 159 N.E. 416 (1927); Dixon-Reo Co. v. Horton Motor Co., 49 N.D. 304, 191 N.W. 780 (1922); see Trubowitch v. Riverbank Canning Co., 30 Cal.2d 335, 344, 182 P.2d 188 (1947); Dickson v. St. Paul, 97 Minn. 258, 106 N.W. 1053 (1906); George v. Richards, 361 Pa. 278, 64 A.2d 811 (1949).

314. E.g., Butler v. San Francisco Gas \& Electric Co., 168 Cal. 32, 141 Pac. 818 (1914); see CorbIN, op. cit. supra note $299, \$ 872$. UCC \$ 2-210(3) provides : "Unless the circumstances indicate the contrary a prohibition of assignment of 'the contract' is to be construed as barring only the delegation to the assignee of the assignor's performance." 
the limitations as preventing only voluntary assignments and not those which occur by operation of law. ${ }^{315}$ A distinction has also been drawn between claims for money and other contract rights, the courts concluding that only the latter were intended to be subject to the restriction on assignment. ${ }^{316}$ Similarly, the courts have differentiated rights arising under a contract from those arising from a breach of the contract, interpreting nonassignability clauses as applying only to the former. ${ }^{317}$

It is not always possible, however, for a court to avoid determining the validity of a restriction on assignment by interpreting it as not preventing the particular assignment in dispute. Sometimes the contract may be so worded as to preclude such a conclusion. . $^{318}$ The few cases which have ruled directly on the question have dealt with assignments of claims for payment of money. These cases reveal a split in opinion.

The courts which have sustained limitations on assignment have done so on the theory that people are free to contract as they wish in the absence of a compelling reason for limiting that freedom. ${ }^{319}$ Courts denying effect to terms prohibiting assignment have considered that contract rights are property, the alienation of which cannot be restrained. ${ }^{220}$ Neither of these assertions is determinative, however; each merely states, in doctrinal terms, one of the two conflicting policies. That freedom of contract is not an absolute command is clear; at times an equally respected public policy requires infringement of this freedom. Whether the policy against restricting the alienability of property applies to rights arising out of a contract is the central issue here.

The policy against restraints on alienation is the outgrowth of the twin desires of developing the maximum productivity from society's limited resources and preventing unreasonable accumulations of wealth. ${ }^{321} \mathrm{Re}-$ gardless of the merits of the latter consideration, it appears inapposite to choses in action. Conversely, it seems clear that the ability to assign freely rights arising out of contracts tends to increase the commercial utilization of financial resources. Probably the outstanding example of

315. E.g., California Packing Corp. v. Lopez, 207 Cal. 600, 279 Pac. 664 (1929); Francis v. Ferguson, 246 N.Y. 516, 159 N.E. 416 (1927); see Comment, 35 CalIF. L. REv. 577 (1947).

316. Trubowitch v. Riverbank Canning Co., 30 Cal.2d 335, 182 P.2d 182 (1947); see Omaha v. Standard Oil Co., 55 Neb. 337, 75 N.W. 859 (1898); Dixon-Reo Co. v. Horton Motor Co., 49 N.D. 304, 191 N.W. 780 (1922).

317. Trubowitch v. Riverbank Canning Co., 30 Cal.2d 335, 182 P.2d 182 (1947); Fuller v. Favorite Theaters Co., 119 Utah 570, 230 P.2d 335 (1951).

318. See New York Trust Co. v. Island Oil \& Transp. Corp., 34 F.2d 653 (2d Cir. 1929); Allhusen v. Caristo Constr. Corp., 303 N.Y. 446, 103 N.E.2d 891 (1952).

319. See Allhusen v. Caristo Constr. Corp., 303 N.Y. 446, 103 N.E.2d 891 (1952); Concrete Form Co. v. W. T. Grange Constr. Co., 320 Pa. 205, 181 Atl. 589 (1935); cf. Grismore, Effect of a Restriction on Assignment in a Contract, 31 MICH. L. REv. 299, 317 (1933).

320. Portugueses-American Bank v. Wells, 242 U.S. 7 (1916) ; State St. Furniture Co. v. Armour \& Co., 345 I11. 160, 177 N.E. 702 (1931); Comment, 31 MICH. L. REv. 236 (1932); see Georgia Co-op Fire Ass'n v. Borchart \& Co., 123 Ga. 181, 51 S.E. 429 (1905).

321. See Schnebly, Restraints Upon the Alienation of Legal Interests: I, 44 YALE L.J. 961, 964 (1935). 
the commercial use of assignment is accounts receivable financing. This means of stimulating a supply of credit has become exceedingly popular because it enables the businessman to convert what otherwise would be dormant accounts receivable into available working capital. ${ }^{322}$ In this respect the ability to assign assumes great social significance for, if our economy is fully to realize its potential, it is essential that all sources of capital be available. ${ }^{323}$

On the other hand, although preserving freedom of contract for its own sake is meritorious, there seems little else to justify enforcing a restriction on assignability of contract rights. The debtor's most forceful contention is his desire to deal only with those of his own choosing. ${ }^{324}$ Since payment of the debt in issue may be the extent of debtor's dealings, no significant interest is involved when this preference is arbitrary. However, the preference may be founded on practical commercial considerations. Once notice of assignment is given, the debtor faces the risk of paying the wrong person, for he may be unfamiliar with the assignee and usually will have only the assignee's word as proof of the assignment. Section 9-318(4) of the code, however, provides a solution to this problem which covers most assignments of rights to payment:

“. . . Before making payment, an account debtor may, however, require an assignee to furnish reasonable proof of the making of the assignment. Until an assignee furnishes reasonable identification of the account or contract right assigned, the account debtor may make payment to the assignor."

322. Note, 1952 Wis. L. REv. 740, 744.

323. Ibid. Conceivably accounts receivable could be made the basis of a loan without being assigned; the borrower merely would promise to pay the lender the proceeds of the accounts as they are received. However, the danger that the borrower may use the receipts for purposes other than paying off the loan, together with the possibility that in bankruptcy the accounts may be subject to the claims of other creditors, would make this type of arrangement unattractive.

Another common situation in which assignment performs the function of protecting a creditor from the potential fraud of his debtor is in the financing of construction contracts. Typically the contractor assigns his right to payment under his contract to a bank as security for a loan. This differs from the accounts receivable situation only in that, at the time of the assignment, the right to payment has not yet been earned.

Assignment is also a useful device where the assignor wishes to step out of a particular transaction. Consider a sale of a going business that includes the sale of a plant, and suppose there is a contract, not yet completed, to install machinery in that plant. From the standpoint of both the btyyer and the seller of the business it is desirable that the buyer become the one entitled to demand performance on the machinery contract. The buyer wants to be able to control performance because he is the one who is going to use the machinery and who will suffer if it is faulty. At the same time, having sold his plant, the seller no longer has any use for the machinery and certainly would not want to be burdened further with the contract. $C f$. Hansen v. E. I. Bruce Co., 162 Neb. 759, 77 N.W.2d 458 (1956) (Contract to insulate a house against attacks of subterranean termites assigned by seller of house to buyer of house). These same considerations make the delegation of duties desirable if the contract is still executory. See pp. 914-15 infra.

324. Omaha v. Standard Oil Co., 55 Neb. 337, 75 N.W. 859 (1898); Grismore, supra note 319 , at 317 . 
Another consideration advanced is that prohibiting the assignment of rights to payment not yet earned by performance is a reasonable means of assuring that the assignor will not be without incentive in performing the contract. $^{325}$ This argument is premised on the belief that the quality of performance will decline once the assignor has divested himself of his benefits under the contract. ${ }^{326}$ While this may be correct psychology for contracts of personal service, it would not seem applicable to contracts for the sale of goods under modern commercial conditions. Where standardized goods are manufactured by mass production methods without being identified to any particular order, there is little danger of deterioration in quality as the result of an assignment. ${ }^{327}$ Moreover, the hope of obtaining future orders and the desire to maintain a good business reputation seem sufficient incentive to maintain production standards. Furthermore, protection from performance by the assignor which would be so inferior as to amount to a breach is afforded the obligor by his ability to avoid payment in such event. In addition, the assignee will normally have a right of action against the assignor if the entire payment is not received from the obligor. ${ }^{328}$

It is arguable that one consideration in selecting a party with whom to contract may be his potential willingness to settle a claim rather than press an action to recover full damages, and that to give effect to this consideration restrictions on assignment should be enforced. Aside from the questionable social desirability of recognizing such a motive, its applicability in any case would be highly speculative. Certainly this argument is not sufficient of itself to reject the code's position if it is otherwise desirable. ${ }^{329}$ Possibly a more forceful contention is the obligor's desire to limit the likely venue of a law suit.

Whether one favors the code's position in negating restrictions on the assignability of certain rights depends upon the weight one gives to the social value of accounts receivable financing and other commercial uses of assignment when compared with the desire for freedom of contract. Aside from the merits of the rule, in place of the prior confusion, the code's formulation does achieve the commercially desirable goal of predictability.

325. Sacks v. Neptune Meter Co., 144 Misc. 70, 71, 258 N.Y. Supp. 254, 256 (2d Dep't 1932).

326. See Fenn v. Pickwick Corp., 117 Cal. App. 236, 4 P.2d 215 (1931) ; Paper Products Mach. Co. v. Safepack Mills, 239 Mass. 114, 131 N.E. 288 (1921).

327. Cf. Gilmore, On the Difficulties of Codifying Commercial Laze, 57 YALE L. J. 1341 (1948).

328. Strictly speaking, an assignment does not give rise to an implied warranty by the assignor that the obligor will perform. Galbreath v. Wallrich, 45 Colo. 537, 102 Pac. 1085 (1909). However, most commercial assignments are made as security for loans and the assignee normally would have an action on the loan agreement.

329. The assignment of an executory contract may create difficulties should the original parties to the contract subsequently desire to modify or rescind their original agreement. Where the assigned right is a "contract right" $\$ 9-318(2)$, discussed pp. 918-20 infra, adequately protects the obligor from injury as the result of an assignment. Where the executory right is other than a "contract right" the code does not invalidate a prohibition on assignment. See text at p. 908 supra. 
Material Change in Performance-Some New Aspects of the Problem

In applying the code's prohibition of assignment, unless otherwise agreed, where the assignment would "materially change the performance of the other party," two special problems deserve attention. The first concerns the assignability of the buyer's right to receive goods under a requirements contract; the other involves the effect of the seller's privilege of "cure" on the transferability of any contract right.

\section{Requirements Contracts}

Assignment of the buyer's right to receive goods under requirements contracts have at times been denied enforcement. The usual ground in such cases is that in the nature of the arrangement the other party to the contract probably had reposed a "trust and confidence" in the particular person with whom he had contracted and, therefore, he should not be required to deal with a different individual. ${ }^{330}$ Underlying this rationale is the fear that abuse could result by the substitution of a new party having markedly different requirements. ${ }^{331}$

This difficulty should be alleviated by section 2-306(1) of the code. Under this provision "requirements" are defined as ". . . such actual . . requirements as may occur in good faith. . . ." 332 Good faith means "honesty in fact" 333 and the observance of "reasonable commercial standards." 334 Furthermore, ". . . no quantity unreasonably disproportionate to any stated estimate or in the absence of a stated estimate to any normal or otherwise comparable prior . . . requirements may be tendered or demanded." 335 In providing these reasonably objective criteria for determining the scope of the obligor's duty to the assignor under a requirements contract, and hence limiting the need for the obligor to rely upon the other party's discretion, the code meets the objection that an assignment would force the obligor to fill orders where the quantity is dependent on the determinations of a person or company with whom he may not have desired to deal. ${ }^{336}$

\section{"Cure"}

The code confers on a seller the privilege of curing a nonconforming tender..$^{337}$ This advantage may be diminished should a buyer assign his

330. Crane Ice Cream Co. v. Terminal Freezing \& Heating Co., $147 \mathrm{Md}$. 588, 128 Atl. 280 (1925); accord, Paper Products Mach. Co. v. Safepack Mills, 239 Mass. 114, 131 N.E. 288 (1921) ; see CoRBIN, op. cit. supra note $299, \$ 884$.

331. See Crane Ice Cream Co. v. Terminal Freezing \& Heating Co., $147 \mathrm{Md}$. 588, 128 At1. 280 (1925).

332. UCC \& 2-306(1).

333. UCC \& 1-201(19).

334. UCC $\$ 2-103(1)(\mathrm{b})$.

335. UCC \& 2-306(1).

336. See UCC \& 2-210, comment 4. The UCC provisions on requirements and output contracts are discussed at length in Note, Requirement Contracts Under the Uniform Commercial Code, 102 U. PA. L. REv. 654 (1954).

337. UCC $\$ 2-508$ provides: "(1) Where any tender or delivery by the seller is rejected because non-conforming and the time for performance has not yet expired, 
right to receive goods to someone in a more distant location. For instance, a Pennsylvania seller may contract to sell machinery, terms f.o.b. seller's city, to a Pennsylvania buyer who assigns the right to the goods to someone in California. ${ }^{338}$ If, when received, the machinery is found to be defective the seller might attempt to "cure" in one of two ways. He could either ship another machine or send his mechanics to repair the machinery now in the buyer's possession. Where the later alternative is desirable the increased difficulty in effecting a "cure" is apparent.

If the ability to cure was a material consideration in the contract negotiations, an assignment infringing on this privilege should be unenforceable. Normally cure would not be a factor, however. ${ }^{339}$ As a result a court should require very convincing evidence before invalidating an assignment of a right to goods on this ground. Although the protection afforded sellers who tender defective goods is meritorious, the commercial significance of free assignability of contract rights seems to warrant greater consideration.

\section{Substituted Performance-Delegation of Duties}

At times an obligor may find it convenient, or perhaps even necessary, to relieve himself of the duty of performance under his contract. ${ }^{340}$ If he can locate a party willing to assume his contractual obligations, the obligor may then be able to delegate his performance provided the code's rules and the terms of his contract are observed.

the seller may seasonably notify the buyer of his intention to cure and may then within the contract time make a conforming delivery.

"(2) Where the buyer rejects a non-conforming tender which the seller has reasonable grounds to believe would be acceptable with or without money allowance the seller may if he seasonably notifies the buyer have a further reasonable time to substitute a conforming tender."

338. Requiring delivery to a distant destination would not necessarily "materially change" the seller's performance-if the buyer is paying the freight the only difference to the seller would be that he would have to write a different address on the shipping documents-unless the word "performance" in \$ 2-210(2) is interpreted to include the seller's cure. The latter is certainly not a natural interpretation. Recently it has been proposed that $\S 2-210(2)$ 's definition of what rights are assignable be amended to preclude an assignment if it would "... increase materially the burden or risk imposed on him [the other party] by his contract. ..." Article 2, 1957 DRAFr. The word "risk" would seem broad enough to cover impairment of the ability to cure. It is necessary, however, in determining when the impairment of the ability to cure would prevent assignment, to bear in mind the "increase materially" and "imposed ... by his contract" conditions of this clause. This latter language would seem to call for an inquiry into the importance which the availability of the privilege to cure had in inducing the parties to enter into the contract.

339. Where there is real concern over the possibility of defective delivery the more common solutions are to provide for arbitration or for adjusting the contract price. The inherent difficulties in effecting a cure when the goods are in a distant location make $\$ 2-508$ a far from satisfactory solution to the problems which arise when a buyer complains that the tender was defective. See Honnold, Bityer's Right of Rejection, 97 U. PA. L. REv. 457, 474 (1949).

340. Illustrative of such a situation would be an assignment of an executory contract for the sale of goods by the vendor in conjunction with the sale of his business. The vendor, since he is going out of business, no longer will be in a position to supply the goods. It would be convenient if he could have someone, the obvious choice being the person buying the business, complete the contract. See note 303 supra. 
Normally, the duty delegated is that of providing goods or services. In some instances the duty to pay for the obligor's performance may be delegated. This would ordinarily occur when the obligee both assigns his right to receive the performance and delegates his duty to pay for it. Seldom is it important to a creditor whether he is paid by one party or another. Accordingly, the right to delegate this obligation is usually not precluded by contract terms or by statutory or judicial rules. The use of machinery and mass production methods to produce a standardized product tends to eliminate the reliance placed upon the identity of the producer. Similarly, where testing and grading by independent agencies or the Government is involved, dependence on the skill or honesty of the performer is less significant. Recognizing that delegation of performance normally is unobjectionable, section 2-210(1) of the code sanctions it except where it is shown that the delegated performance would not be as satisfactory as that of the original contracting party. Subsection one reads :

"A party may perform his duty through a delegate unless otherwise agreed or unless the other party has a substantial interest in having his original promisor perform or control the acts required by the contract. No delegation of performance relieves the party delegating from liability for any breach." 341

It should be noted that agreements prohibiting delegation are given full effect by the above rule, thus presenting an interesting, although not inconsistent, contrast with the rules previously discussed on contract terms prohibiting assignment. Several considerations may impel a contracting party to be willing to accept only the performance of a particular individual or firm: reliance may be placed either on that party's ability to meet his production schedules or on the quality of his product. Furthermore, some significance may be attached to unique characteristics of one supplier's goods or perhaps commercial acceptability of his particular brand name, irrespective of the comparable quality of another's product. There appearing no overriding public policy to the contrary, the parties should be free to restrict delegation pursuant to their own evaluation of the weight to be given such considerations.

The code also inhibits delegation when the obligee has a "substantial interest" in having his original promissor perform. Some contractual duties by their very nature suggest that performance by a substituted party was not contemplated.342 Examples of such duties are those imposed by

341. This last sentence codifies what has always been the law and what is an obvious requirement, e.g., Brown v. Bowers Constr. Co., 236 N.C. 462, 73 S.E.2d 147 (1952); REsTATEMENT, CoN'rRACTs \& 160 (4) (1932); CoRBIN, op. cit. supra note 299, \$ 866. If delegation of the responsibility for performance were permitted, contractual obligations might be avoided simply by delegating them to someone who is judgment proof.

342. The obligee, of course, may waive his right to demand personal performance. Failure to object to performance by a delegate may operate as a waiver. See Denton v. Brocksmith, 299 Fed. 559 (5th Cir. 1924). 
personal service contracts ${ }^{343}$ or by contracts calling for the exercise of the promisor's skill or knowledge. ${ }^{344}$ Pre-code cases have held it improper to delegate such obligations. Since primary consideration has been given to protecting the obligee from having to accept something different than what he bargained for, the court's task will essentially be one of ascertaining the "basic assumption" on which the contract was founded. The "substantial interest" test would seem to continue this policy.

\section{The Right to Assurances of the Delegate's Performance}

Where an obligor is permitted to delegate his duty to perform, the code in section 2-210(5) seeks to protect the obligee by authorizing him to demand assurances of due performance. ${ }^{345}$ A right to assurances normally arises only when the obligee's expectation of performance has been impaired, in which case he may suspend his own performance until assurances are forthcoming and treat a failure to provide such assurances within a reasonable time not exceeding thirty days ${ }^{346}$ as a repudiation of the contract.. ${ }^{347}$ The effect of section 2-210(5) is to confer these rights on an obligee whenever there is an assignment which delegates performance regardless of whether the delegation does in fact create reasonable grounds for insecurity.

The obligee's right to demand assurances in assignment situations originated in the common law. For example, in Pardee $v$. Kanady, ${ }^{348}$ where prior to insolvency a buyer assigned his right to receive lumber and also delegated the duty to pay for it, the court indicated that the assignee-delegee could demand the lumber only upon a showing that he was able to pay the seller on delivery. Similarly, in Brassel $v$. Troxel, 340 it was intimated that the assignee-delegee could demand performance if he provided security for payment. The code enlarges the protection afforded the

343. E.g., Wetherell Bros. Co. v. United States Steel Co., 200 F.2d 761 (1st Cir. 1952). The performance of a contract for support can not be delegated. Tough v. Netsch, 83 N.H. 374, 142 Atl. 702 (1928).

344. E.g., Walker Electric Co. v. New York Shipbuilding Co., 241 Fed. 569 (3d Cir. 1917).

345. UCC \& 2-210(5): "The other party may treat any assignment which delegatès performance as impairing his expectation of performance and may without prejudice to his rights against the assignor demand assurances from the assignee (Section 2-609)."

346. UCC \& $2-609(4)$.

347. UCC \& 2-609(1) provides: "A contract for sale imposes an obligation on each party that the other's expectation of receiving due performance will not be impaired. When reasonable grounds for insecurity arise with respect to the performance of either party the other may in writing demand adequate assurance of due performance and until he receives such assurance may if commercially reasonable suspend any performance for which he has not already received the agreed return."

348. 100 N.Y. 121, 2 N.E. 885 (1885). See also In re Niagara Radiator Co., 164 Fed. 102 (W.D.N.Y. 1908).

349. 68 I11. App. 131 (1896). 
obligee in these cases by, first, no longer requiring grounds for actual insecurity, such as insolvency of a buyer-assignor, and second, by making the obligee of the delegated performance the moving party concerning assurances. Rather than requiring an assignee to give security if he wants to compel performance, the code authorizes the obligee to demand assurances before proceeding with his own performance. The obligee is thus enabled to discover speedily and with certainty whether he will be obliged to perform, avoiding the problem faced by the seller in Pardee v. Kanady of having either to prove the assignee's inability to pay or to tender performance in order to find this out.

Since section 2-210(5) applies to "any assignment which delegates performance," it may be contended that the provision is operative only when the delegation of performance is accompanied by an assignment of rights. This interpretation construes "assignment" in its technical sense rather than as a generic term relating to any transfer whether it be of a right or a duty. The draftsmen's non-technical use of the term in the comment to section $2-210^{350}$ raises doubts as to the likelihood that it is used technically in the text. Furthermore, since such a limitation seems inexplicable, ${ }^{351}$ the section should probably be construed as applying to all instances involving delegation of performance. Nevertheless, to avoid possible doubt or misconstruction, it may be wise to amend section 2-210(5) to apply to "any delegation of performance" irrespective of its accompaniment by an assignment of rights.

\section{Construing the Terms of the Assignment}

Where there is an "assignment" of an interest in an executory contract, a question arises as to whether the assignee can be required by the other party to perform the contract. The answer, of course, is affirmative only if there is also a delegation of duties and if the transaction between the assignor and the assignee can be interpreted as creating a third party beneficiary contract under which the obligee can enforce the assignee's promise to perform. ${ }^{352}$ But businessmen often use such expressions as "assignment," "rights" or "contract" without full awareness of their strict legal implications; that an "assignment" of "rights" or of a "contract" is intended to include a delegation of duties is not unusual. Since these terms may find their way into a commercial contract without any evidence indicating the intended meaning, a rule of construction seems appropriate. The

350. UCC § 2-210, comment 5; but cf. UCC \$ 2-210, comment 1.

351. It should be remembered that a promisee primarily will be interested in obtaining return performance, and only secondarily in the right to bring a law suit. UCC $\$ 2-609$, comment 1 .

352. Grismore, Is the Assignee of a Contract Liable for the Non-Performance of Delegated Duties, 18 MICH. L. REv. 284 (1920); cf. CoRBIN, op. cit. subra note $299, \S 776$. 
code, in section 2-210(4), sets forth a general principle for interpreting these terms:

"An assignment of 'the contract' or of 'all my rights under the contract' or an assignment in similar general terms is an assignment of rights and unless the circumstances indicate the contrary (as in an assignment for security) it is a delegation of performance of the duties of the assignor and its acceptance by the assignee constitutes a promise to perform those duties. This promise is enforceable by either the assignor or the other party to the original contract." ${ }^{353}$

This approach is essentially that expressed in section 164 of the Restatement of Contracts. Some states, notably New York, ${ }^{354}$ have not followed the Restatement view, but instead construe the aforementioned phrases as an assignment of rights alone, requiring that for a delegation of duties the parties expressly so provide. ${ }^{355}$

Each of these rules of construction has merit. The code apparently attempts to achieve the result the parties intended. It is submitted that the normal understanding attached by a layman to the expressions "assignment of the contract" or "all of my rights under the contract" is that the assignor has severed his connection with the contract. ${ }^{356}$ Furthermore, unless the purpose of the assignment was to provide security for a loan, it seems unusual that only the rights would be assigned, with the assignor remaining liable for performance of the duties. The likelihood that the assignor's obligation depends on the other party's return performance indicates that the normal intention is for the assignor's duty of performance also to be transferred to the assignee who is in a better position to judge the conformity of the other party's performance. ${ }^{357}$ Similarly, since the assignee's right to receive the assigned performance may depend on the proper performance of the assignor's duties, ${ }^{358}$ the assignee would wish to control that performance himself rather than rely upon the assignor.

On the other hand, the New York type rule can be justified as a choice which would work the least inequity if its application produced a result contrary to that actually intended by the parties where such intentions are

353. It has been proposed that UCC $\S 2-210(4)$ be amended so as to read: ". . . unless the language or the circumstances (as in an assignment for security) indicate the contrary. ..." 1957 DRAFT. The words in italics represent the amended portions. The amendment does not appear to effect any change in meaning.

354. Langel v. Betz, 250 N.Y. 159, 164 N.E. 890 (1928). If the assignee sues the obligor, rather than vice-versa, then even in New York the assignee would have to perform the assignor's duties. See Kaufman v. William Iselin \& Co., 272 App. Div. 578, 74 N.Y.S.2d 23 (3d Dep't 1947).

355. Langel v. Betz, 250 N.Y. 159, 164 N.E. 890 (1928). The assignee may subsequently adopt the contract. In re Baylies' Estate, 155 Misc. 431,279 N.Y. Supp. 415 (Sup. Ct. 1935).

356. See Grismore, supra note 352 , at 288.

357. Ibid.

358. See UCC § 2-609(1). 
incapable of being proved. The code rule could shift the duty to perform to one who had never contemplated doing so; New York's rule would continue to require performance by the original contracting party. Nevertheless, since the code's approach would probably conform more often to the parties' intention, it seems to be the better rule.

\section{Modification of Assigned Contracts}

Prior to receiving notice of an assignment, an obligor may deal with the assignor as if there had been no assignment; furthermore, any defense which may be acquired during this period will be good in a subsequent suit by an assignee..$^{359}$ Otherwise the obligor, lacking notice, might perform for the wrong person and then have to perform again through no fault of his own. ${ }^{360}$ Once the obligor has been notified of the assignment this consideration is no longer operative, with the result that, unless he can invalidate the assignment, the obligor must bear the loss caused by his disregard of the assignment. However, commercial convenience or necessity may make modification of the original contract desirable. ${ }^{361}$ Some confusion has arisen in pre-code cases as to the right of the original parties to an assigned contract to alter their agreement without obtaining the assent of the assignee. ${ }^{362}$

Section 9-318(2) of the code resolves this confusion in the situation in which it most commonly arises-the assignment of an unmatured claim for money. ${ }^{363}$ Within this narrow area the draftsmen chose to relieve the obligor from the necessity of obtaining the assignee's assent to a modification. Such a solution seems warranted in the area in which it was designed (1932).

359. Corbin, op. cit. supra note $299, \S 904$; Restatement, Contracts $\$ 170$

360. See CoRBIN, op. cit. supra note 299, $\$ 904$.

361. See 1 Birnaaum, Sefured Transactions Under The Uniform CommerCIAL CODE \& 31.15 (1954).

362. The confusion stems from the resulting conflict between two general principles of the law of assignment. The first is the rule that an assignee takes subject to the defenses which the obligor had against the assignor and, therefore, cannot recover if the assignor could not have done so. Corbin, op. cit. supra note 299, § 892 ; RESTATEMENT, CoNTRACTS $\$ 170$ (1932). Behind this rule is the idea that the position of the debtor should not be made any worse as the result of an assignment. On the other side is the rule that, once notice has been given, an assignment extinguishes the assignor's right to receive, and therefore to excuse, the obligor's performance. Friedberg v. Jablon, 287 Mass. 510, 192 N.E. 49 (1934) ; CorBin, op. cit. supra note 299, $\$ 891$; Restatement, Contracts $\$ 170$ (1932). Here the purpose is to protect the assignee from being deprived of his claim as the result of the bad faith of his assignor. M'Cullum v. Coxe, 1 Dallas 139 (Pa. 1785); see Petty v. Hall, 257 Ala. 145, 147, 57 So.2d 620, 621 (1952).

363. UCC $\$ 9-318(2)$ : "So far as the right to payment under an assigned contract right has not already become an account, and notwithstanding notification of the assignment, any modification of or substitution for the contract made in good faith and in accordance with reasonable commercial standards is effective against an assignee unless the account debtor has otherwise agreed but the assignee acquires corresponding rights under the modified or substituted contract. The assignment may provide that such modification or substitution is a breach by the assignor." 
to apply. Large scale procurement, especially by the Government, at times necessitates modifying the agreed performance of numerous subcontractors. ${ }^{364}$ By pre-code contract doctrine the party instituting the change, e.g., the prime contractor, would have to negotiate not only with perhaps hundreds of subcontractors, but also with the numerous institutions which financed these parties and which are assigned the right to payment as security for the loan. Obtaining the assent of all these persons would involve the expenditure of a great deal of time ${ }^{365}$ and effort. In accordance with the objective of avoiding this burden, the code dispenses with the assignee's assent to modification only where the assignment is of a "contract right" - a right to payment not yet earned by performance. Once the assignor has performed and the "contract right" has become an "account" right-an earned right to payment-any modification would be with regard to payment alone and would require the assent of the assignee. Furthermore, the assignee is protected by the requirement that in order to be effective against him a modification must be made "in good faith and in accordance with reasonable commercial standards" 366 and by the proviso that the assignee automatically acquires corresponding rights under the modified or substituted contract. ${ }^{\mathbf{3 6 7}}$ Since failure to observe these requirements will leave the obligor liable on the original contract, the effect is to make the obligor the watchdog of the assignee's rights.

The code also specifies that the assignee may provide in the assignment that modification of the assigned contract without his consent is a breach. ${ }^{368}$ Although such a provision will not prevent a modification from being effective, it will permit the assignee recourse against the assignor for any damages sustained thereby. However, it seems clear that the assignor's breach of such a term in the assignment will not subject the obligor to liability.

Since the authorization to modify without procuring the assent of the assignee is contained in article 9, only when there has been a financing sale of contract rights would the code excuse the obligor and assignor from contacting the assignee. A modification impairing the assignee's claim in a secured transaction is not as serious as it might be in the case of an assignment whereby the assignee assumes the risk of collecting from the obligor. Frequently the face amount of the assigned payment exceeds the value of the loan, thereby permitting some leeway for reduction in the amount to be paid before the assignee will suffer a loss. Furthermore, if the assignee's claim is impaired he has an unquestionable right to proceed against the assignor for the unpaid amount of the loan. ${ }^{369}$ To the extent

364. UCC 9-318, comment 2.

365. The time element is significant for there may be penalties for failure to complete a job on time. See St. Mary's Bank v. Cianchette, 99 F. Supp. 994, 997 (D. Me. 1951).

366. UCC \& 9-318(2).

367. Ibid.

368. Ibid.

369. See note 328 supra. 
that the lending institution assumes a greater risk under the code provision, it can provide against it by increasing its interest charge and/or requiring a greater margin of security when making such loans. An added consideration is the undesirability of requiring the obligor to deal with the assignee, a party he did not originally contract with, in order to obtain a modification. In relieving the obligor of the necessity of obtaining the assignee's assent the code not only affords a more orderly process for achieving such modifications, but also by charging the creditor-assignee with the primary risk it enables the risk element to be better allocated between the parties to the loan-assignment transaction.

The code's rule would, however, operate in some situations where its rationale-so far as it appears from the draftsmen's comment-would not apply, i.e., where no great practical burden would be imposed by requiring the procurement of the assignee's assent. For example, a builder in return for a loan may assign to a bank his right to payment for construction of a house to the buyer's order. Modifications may occur several times during construction, possibly warranting a reduced price. So long as the modifications are made in "good faith" and conform to "reasonable commercial standards," the code clearly dispenses with any need to obtain the bank's assent thereto. There being only one assignee, no significant expenditure of time or effort would be involved in obtaining such assent here, although there might be if the project were a larger one and the modifications affected many subcontractors. Whether the result is justifiable in the case of the single house is debatable. ${ }^{370}$ In any event, the draftsmen's dilemma is obvious: in demarcating the zone in which obtaining the assignee's assent is impractical, there must be some overlap into those cases in which it is relatively easy; the goal therefore must be to draw the line so as to create the least inequity. Considering the other factors which, as noted above, alleviate the assignee's risk, the limit set by the code does not seem unreasonable.

\section{CONCLUSION}

Underlying the code's treatment of assignment is the desire to satisfy commercial needs by imparting a greater degree of merchantability to contract rights. This is accomplished primarily by denying effect to contract terms prohibiting certain assignments. Furthermore, by ending the confusion present in prior law with regard to modification of certain assigned rights, traffic in these claims is enhanced. With respect to delegating performance, the code works little change in prevailing law. Only in the requirement that a delegee gives assurances that his performance will be forthcoming is existing law altered. This innovation should make delegation less objectionable in many situations.

370. If the parties are continually making relatively small changes, a requirement that they obtain the assignee's assent to each alteration is quite burdensome. Although the need for the code rule in this situation is not as pressing, it still may be desirable. 


\section{BEYOND THE CODE: APPLICATION AND ANALOGY}

It might be inferred that sections of article 2 of the code which are not specifically restricted to sales of goods were meant to apply more broadly. ${ }^{371}$ This issue was resolved by the code's first supplement, which added a statement that "unless the context otherwise requires, this article applies to transactions in goods. . . ." 372 It could be argued that the law in Pennsylvania is unsettled unless effect is given a cryptic comment accompanying the supplement which states that the change "eliminates any ambiguity as to the application of article 2 to contracts not for the sale of goods." 373 Despite drafting deficiencies, and assuming that article 2 deals only with those topics to which the supplement directs attention, the possibility of application by analogy must be considered.

If code provisions answer some of the contract problems when goods are involved, they might also provide solutions for perplexities in other types of business dealings. That the code is designed for sales of goods does not mean that the draftsmen wanted to avoid effects on a wider front or that code provisions would prove disastrous to other transactions. Rather it is indicative that the draftsmen were focussing upon the needs of one segment of commercial law and gave no heed to other problems. Courts should feel free to extend, by analogy, the code's application if there are positive policy reasons for doing so. Preliminarily, analysis is needed of the available doctrinal means as well as articulation of the governing standards for extension.

One court has already used the code as precedent to help construe a contract not subject to its provisions, observing that code provisions "which do not conflict with statute or settled case law are entitled to as much respect and weight as courts have been inclined to give the various Restatements. It, like the Restatements, has the stamp of approval of a large body of American Scholarship." 374 The code itself invites the use of Sales article principles in dealing with investment securities. ${ }^{375}$ Indeed, several decisions

371. Some sections are specifically applicable only to sales of goods; see UCC $\S \S 2-203,2-204(3), 2-205,2-206(1)(\mathrm{b})$; others can apply to nothing else, e.g., UCC $\$ 2-206(2)$. There are some sections or subsections, however, which apply rather to a "contract," e.g., \$\$2-204(2), 2-206(1) (a), 2-207(2), 2-210, or a "contract for sale," e.g., $\$ \$ 2-204(3), 2-208$, or merely to a "requested performance," e.g., \$2-206(3). A contract for sale is not defined but is stated by $\S 2-206(1)$ to "include" present sales of goods and contracts to sell goods at a future time; there is no indication that the inclusion is as well a restriction.

372. UCC \$2-102 (Supp. 1 1955); see UCC \$\$ 2-105, 2-102.

373. Id. comment. (Emphasis added.) Supplement 1 has not yet been made the law of Pennsylvania.

374. Fairbanks, Morse \& Co. v. Consolidated Fisheries Co., 190 F.2d 817, 822 n.9 (3d Cir. 1951).

375. UCC $\$ 2-105$, comment 1 : "It is not intended by this exclusion, however, to prevent the application of a particular section of this Article by analogy to securities ... when the reason of that section makes such application sensible and the situation involved is not covered by the Article of this Act dealing specifically with such securities (Article 8)." 
have resorted to the Uniform Sales Act in prescribing remedies for sellers and buyers of stocks, albeit not without vigorous dissent. ${ }^{\mathbf{3 7 6}}$ Nonetheless, the attorney seeking the application of code rules to transactions other than sales of goods must combat the "orthodox common law attitude toward legislative innovations" which induces judges to ". . . refuse to reason from it [a statute] by analogy and apply it directly only . . . also to give to it a strict and narrow interpretation, holding it down rigidly to those cases which it covers expressly." ${ }^{377}$ Despite this concern, courts have used statutory material in other areas to obtain results which they considered proper. $^{378}$ With the encouragement of eminent authorities who recommend common-law development from statutory starting points, ${ }^{379}$ it is assumed that our courts will at least consider statutory application by analogy.

Considerations must be formulated for determining when to exercise judicial discretion to extend a statute. Several primary factors can be separated for analysis: The first is an assessment of the value of the legislative change to transactions expressly covered. Then comparison is needed of the activity being judged with that for which the statute makes provision; similarity of conditions affords one strong reason for giving analogous treatment. The desirability of uniformity in legal doctrine may add weight to like conditions or outweigh dissimilarities. The lack of uniformity would be most harmful when agreements are composites of several forms of business endeavor. ${ }^{380}$ Against these considerations the courts should weigh the possibility that the current rule is so imbedded in legal doctrine and business practice that change should come only by legislative choice. With these factors foremost, judicial implementation of legislative policy judgments should be accomplished consistently with the need for it.

Turning to the specific problem of analogizing the code's sales provisions, there are two general types of business agreement which are not affected by the code contract rules. First, those transactions involving a sale of things other than "goods" within the meaning of section 2-105; all sales of real property, fixtures and assignment of choses in action fit this

376. E.g., Agar v. Orda, 264 N.Y. 248, 190 N.E. 579 (1934); see also Annot., 99 A.L.R. 269 (1934).

377. Pound, Common Law and Legislation, 21 HARv. L. REv. 385 (1908). See also Freund, Interpretations of Statutes, 65 U. PA. I. REv. 207, 226 (1917) : "It would probably be accepted as an undisputed proposition of English and American Law that statutes are not extended by analogy.

378. E.g., Fairbanks, Morse \& Co. v. Consolidated Fisheries Co., 190 F.2d 817 (3d Cir. 1951); Johnson v. United States, 163 Fed. 30, 32 (1st Cir. 1908); Amory v. Meredith, 7 Allen 397 (Mass. 1863) ; Agar v. Orda, 264 N.Y. 248, 190 N.E. 479 (1934).

379. See note 377 supra. See also Landis, Statutes and the Sources of Law, HaRv. Legal Essays 213, 217 (1934); Stone, The Common Law in the United States, 50 Harv. L. Rev. 4, 12 (1936). Cf. Note, The Use of Criminal Statutes in the Creation of New Torts, 48 Colum. L. Rev. 456 (1948).

380. For instance, bids to a building contractor might encompass prices for services of the subcontractor and for the supplies which he provides. The uniformity factor was cited without analysis in Agar v. Orda, 264 N.Y. 248, 190 N.E. 479 (1934). 
description. In addition, contracts which contemplate activities other than sales are not covered: rentals of goods, leases of property and personal service agreements of all kinds. Discussion of a few instances will suffice to indicate the necessary analysis. There need be no concern with the code treatment of bilateral and unilateral contracts in considering sales of real estate; the contract-making process is a fairly formal one and it is hardly to be expected that any contract for the sale of land will intentionally be unilateral. Because vendor and vendee will probably have the aid of counsel in arranging both the contract and the sale, common law contract rules are probably adequate without supplement by code provisions. On the other hand, on many occasions the reasonable expectations of those who agreed to perform a service were disappointed because the offeror was permitted to revoke his offer until the requested performance was complete. Whether or not the courts abolish all differences between unilateral and bilateral contracts, they could well follow the code's lead in giving the offeree assurance of a binding agreement when he has begun performance and notified the offeror. ${ }^{381}$

When a person adds new terms to an offer to sell real estate, conditions are dissimilar to those which provoked section 2-207. There is generally little need for speed, and the parties, or their agents, usually deal face to face, nor are negotiations accomplished by means of forms which make it likely that additions will appear. All of these factors, plus the rigidity of conveyancing techniques, indicate that the code rules should not be adopted for use in sales of real estate. When brokers arrange sales of securities, speed is an essential and little personal contact between buyer and seller is usually the rule. Despite these similarities to sales of goods, however, the fairly uniform transactions and fluctuating prices argue for the adoption of the common-law rule for changes or additions. The necessity for bargaining as to many terms involved with the rental of goods seems to dictate that the parties negotiate personally; if this is so the code rule for additions would not be needed. On the other hand, if a party to contract litigation builds and rents machines exclusively, and normally carries on negotiations by means of form offers and acknowledgments, the consideration might be otherwise. The same dichotomy may be established where personal service contracts are concerned. When the businessman hires an employee the parties can be forced to negotiate until they reach complete accord. But the same strictness should not be imposed when a carrier accepts by form a request for shipment from a merchant. The analysis is not intended to be exhaustive. Business relations have an infinite variety; it is only essential that courts consider the consequences of legislative innovation in finding solutions to parallel problems.

The efforts of the draftsmen to present a worthwhile codification of contract law have achieved mixed results in the several problem areas dis-

381. See UCC \$2-206(3). But see text at pp. $842-43$ supra. In some jurisdictions this has already been accomplished to some degree by the common law. See RESTATEMENT, Conitracts $\$ 45$ (1932). 
cussed herein. On the whole, the changes in contract law offered by the code seem desirable and the potential uniformity and possibility of greater certainty are welcome contributions to commercial affairs. It is not surprising that many of its provisions require further analysis and possibly amendment. The critic's approach to the code, however, must be with the draftsman's bias : a desire to order business affairs in a flexible but realistic way. Analysis should foster further consideration of the problems explored; if criticism serves its purpose society can hardly lose by the debate.

R. J. L.

J.G.O.

E. N.V.

C. $S$. 